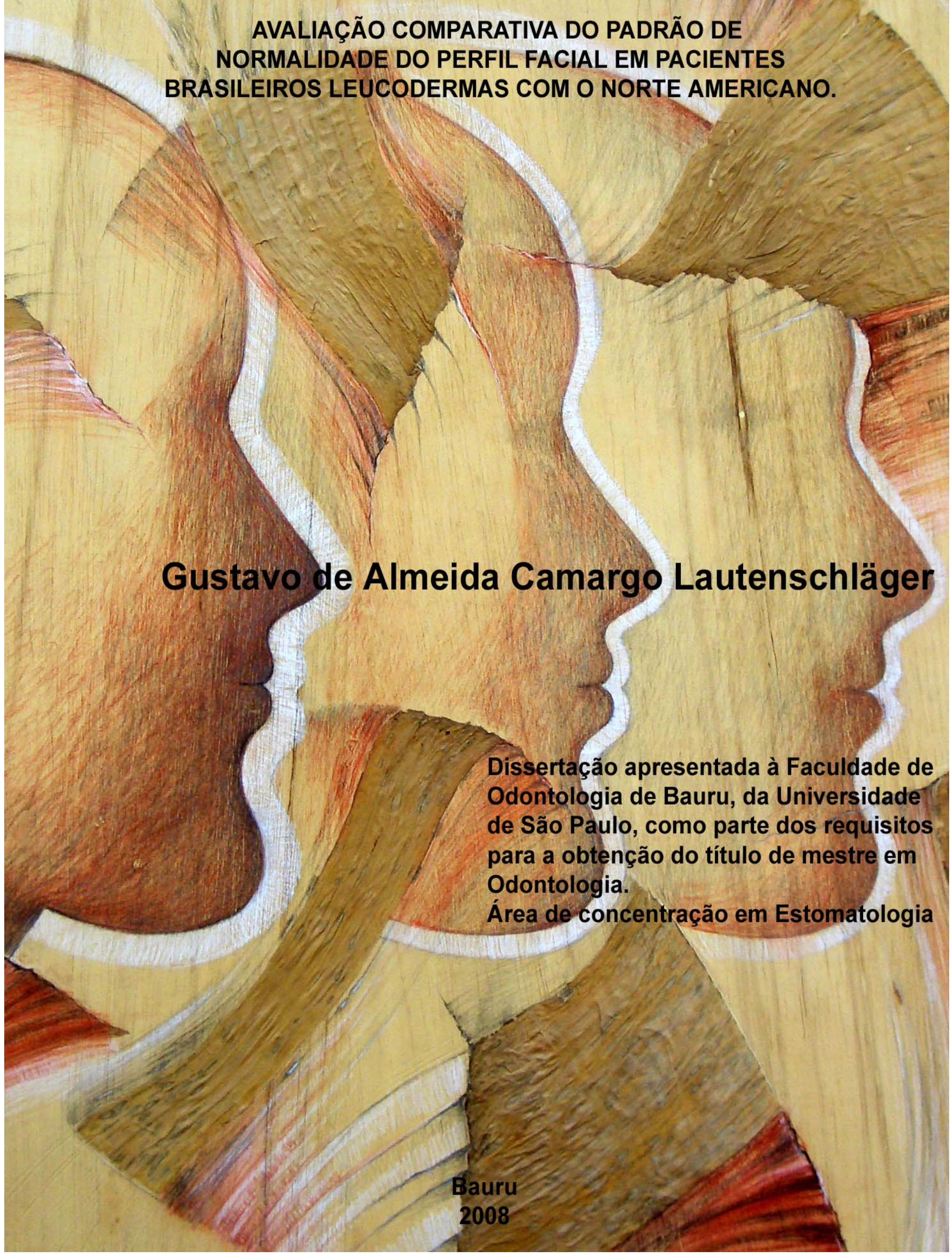





\section{AVALIAÇÃO COMPARATIVA DO PADRÃO DE NORMALIDADE DO PERFIL FACIAL EM PACIENTES BRASILEIROS LEUCODERMAS COM O NORTE AMERICANO.}

\section{Gustavo de Almeida Camargo Lautenschläger}

Dissertação apresentada à Faculdade de Odontologia de Bauru, da Universidade de São Paulo, como parte dos requisitos para a obtenção do título de mestre em Odontologia, área de concentração em Estomatologia

Orientador: Prof. Dr. Eduardo Sant'Ana 
Lautenschläger, Gustavo de Almeida Camargo

Sa59s Avaliação comparativa do padrão de normalidade do perfil facial em pacientes brasileiros leucodermas com 0 norte americano.

124 p.il.;31cm.

Dissertação(Mestrado) - Faculdade de Odontologia de Bauru. USP.

Autorizo, exclusivamente para fins acadêmicos e científicos, a reprodução total ou parcial desta dissertação/tese, por processos fotocopiadores e outros meios eletrônicos.

Assinatura:

Comitê de Ética em Pesquisa em Seres Humanos da Faculdade de Odontologia de Bauru, USP

Processo

Data: (vide ANEXO I). 



\section{Gustavo de Almeida Camargo Lautenschläger}

20 de junho de 1978

Filiação

$1997-2000$

2001

2001-2002

2003

$2005-2008$
Nascimento em Botucatu, SP

Milton Flávio Marques

La utenschläger e Maria Zélia

Camina da de Almeida

Camargo

Graduação em Odontologia na Faculdade de Odontologia de Bauru, Universidade de São Paulo.

Curso de Aperfeiçoamento em Cinurgia pela Sociedade Paulista de Ortodontia

Prática Profissiona liza nte junto a Disciplina de Cirurgia da Faculdade de Odontologia, Universida de de São Paulo.

Aluno especial junto a o curso de Mestrado em Ciências, área de Concentração em Fissuras Craniofacia is no Hospital de Reabilitação de Anomalias Craniofaciais, Universida de de São Paulo

Curso de Mestrado em Odontologia, área de Concentração em Estomatologia na Faculdade de Odontologia de Bauru, Universidade de São Paulo. 



\section{Dedicatória}

A Deus pela vida apaixonante que me deu

A minha noiva: Letícia, pela paciência, compreensão e por todo o seu apoio durantes todos esses anos.

Aos meus pais: Milton Flávio e Maria Zélia, pelo exemplo de luta, dedicação, honestidade e pelo total incentivo a todos os meus passos.

Aos meus irmãos: Milton Flávio e Mariana amigos e companheiros de todas as horas.

Aos meus avós: Eliseu, Deolinda e Zélia avós maravilhosos que valorizam cada passo dado por todos os netos.

A minha família: Tios e primos a todos vocês que desde sempre participaram de todas as fases da minha vida. 



\section{Agradecimentos}

Ao Prof. Dr. Eduardo Sant'Ana meu orientador, mestre e amigo por ter acreditado em mim, e me ajudado a trilhar os caminhos certos, não somente na área acadêmica, mas na vida.

À Faculdade de Odontologia de Bauru, por toda a minha formação.

Aos Professores do Departamento de Estomatologia: Profs.Drs. Osny Ferreira Junior, Paulo Sergio Perri de Carvalho, José Humberto Damante, Luiz Eduardo Montenegro Chinellato, Ana Lúcia Álvares Capelozza e Izabel Regina Fischer Rubira-Bullen.

Aos Funcionários do Departamento de Estomatologia: Roberto Sales, Marília Gião, Patrícia Germino, Luciana Zamon, Josieli Farinha, Fernanda Cavalari, Elza Cassalate, Antonio Roque dos Santos e também aos funcionários Hebe Pereira, Camila Medina, aos amigos da Urgência Dona Ana, Dona Maria, Dona Alice, Regina, Mauro "Mestre" e Luis.

Aos meus queridos companheiros de mestrado Moacir Tadeu Rodrigues, Marta Cunha Lima, Renata Teixeira, Danielle Albuquerque e Letícia Nery que me ensinaram muito sobre Odontologia e principalmente sobre amizade.

Aos meus amigos do Doutorado, Zanda, Etiene, Augusto, Josi, Jordy, Flávio, Cláudio "BA", Eduardo e minha companheira de clínica Carla pelos grandes conselhos e pela grande ajuda. 

Ao Renato Yassutaka Faria Yaedu pela grande ajuda na confecção de todo esse trabalho.

A minha querida amiga Érika Uliam Kuriki, por ter doado tanto tempo, esforço e toda a sua grande competência para que esse trabalho pudesse ser realizado.

Aos amigos e mestrandos, Gabriel “Tanga”, Manuela, Camila, Elen, Marcelo.

Aos meus sogros José Conrado e Carmen pelo grande apoio em Botucatu, pela confiança.

Aos meus cunhados André e Koti meus novos irmãos, pela amizade e grande apoio nas minhas idas a São Paulo.

Aos Amigos da Turma XXXVI, uma turma igual a esta não terá jamais.

A todos das clínicas Perfil e Agami por toda a dedicação e apoio.

Aos Funcionários do Ceama de Bauru pela amizade e compreensão com os meus horários alternativos.

Aos amigos de Botucatu por toda a amizade nesses anos todos e pelos tão necessários momentos de descontração. 



\section{Sumário}

LISTA DE FIGURAS viii

LISTA DE TABELAS ix

RESUMO $\mathrm{x}$

1. Introdução 01

2. Revisão de Literatura 07

3. Proposição 51

4. Material e Métodos 55

4.1. Amostra 57

4.1.1 Grupo Experimental $\quad 57$

4.1.2 Grupo Controle $\quad 58$

4.2. Métodos 59

4.2.1 Obtenção das Radiografias Cefalométricas $\quad 59$

4.2.2 A Elaboração dos Cefalogramas 62

4.2.3 Delimitação do desenho anatômico 64

4.2.4 Delimitação dos pontos cefalométricos 65

4.2.5 Delimitação da linha de referência extracraniana $\quad 69$

4.2.6 Grandeza Cefalométrica $\quad 69$

4.3. Análise Estatística 78

5. Resultados 79

6. Discussão 87

7. Conclusão 99

ANEXOS 103

REFERÊNCIAS BIBLIOGRÁFICAS 107

$\begin{array}{ll}\text { ABSTRACT } & 121\end{array}$ 



\section{Lista de Figuras}

Marcadores metálicos posicionados para a realização da radiografia tele lateral. De cima para baixo os marcadores estão posicionados nos pontos cefalométricos da rima orbitária, ponto da maça, ponto da região subpupilar, base nasal e ponto da linha mento-pescoço.

Visualização dos marcadores metálicos na radiografia tele lateral. FIGURA 2 De cima para baixo os marcadores estão posicionados nos pontos cefalométricos da rima orbitária, ponto da maça, ponto da região subpupilar, base nasal e ponto da linha mento-pescoço.

FIGURA 3 Visualização da régua própria do Dolphin

FIGURA 4 Interface do software Dolphin Imaging, versão 9.0.

FIGURA 5

Interface do software Dolphin Imaging, versão 9.0 mostrando o cefalograma.

FIGURA 6 Delimitação do desenho anatômico.

FIGURA 7

Pontos de referência do traçado cefalométrico

FIGURA 8 Linha Vertical Verdadeira.

FIGURA 9

Altura posterior da maxila

FIGURA 10

Ângulo formado pelo incisivo superior e o plano oclusal da maxila.

FIGURA 11

Ângulo formado pelo incisivo inferior e o plano oclusal da mandíbula.

FIGURA 12 Overjet e overbite.

FIGURA 13 Espessura do lábio superior, inferior, pogônio e mento.

FIGURA 14 Ângulo Nasolabial.

FIGURA 15

Ângulo do Lábio Superior.

FIGURA 16

Comprimento facial.

FIGURA 17

Projeção dos pontos cefalométricos do tecido mole em relação à Linha Vertical Verdadeira.

Comparação do padrão brasileiro da análise cefalométrica do tecido mole com o padrão americano. Em vermelho observa-se o perfil do padrão americano, em azul o perfil do tecido mole do padrão brasileiro e em preto, a linha vertical verdadeira. 



\section{Lista de Tabela}

TABELA 1

TABELA 2.1

TABELA 2.2

TABELA 3.1

TABELA 3.2

TABELA 4.1

TABELA 4.2

TABELA 5.1

TABELA 5.2
Erro do método da análise cefalométrica do tecido mole utilizando o software Dolphin.

Comparação das medidas dentoesqueléticas brasileiras da análise cefalométrica do tecido mole com o padrão americano para o gênero feminino.

Comparação das medidas dentoesqueléticas brasileiras da análise cefalométrica do tecido mole com o padrão americano para o gênero masculino.

Comparação das medidas dos tecidos moles brasileiros da análise cefalométrica do tecido mole com o padrão americano para o gênero feminino.

Comparação das medidas dos tecidos moles brasileiros da análise cefalométrica do tecido mole com o padrão americano para o gênero masculino.

Comparação das medidas do comprimento facial dos brasileiros da análise cefalométrica do tecido mole com o padrão americano para o gênero feminino.

Comparação das medidas do comprimento facial dos brasileiros da análise cefalométrica do tecido mole com o padrão americano para o gênero masculino.

Comparação das medidas da projeção à LVV dos brasileiros da análise cefalométrica do tecido mole com o padrão americano para o gênero feminino.

Comparação das medidas da projeção à LVV dos brasileiros da análise cefalométrica do tecido mole com o padrão americano para o gênero masculino. 



\section{Resumo}

Com a grande procura da sociedade moderna pela estética perfeita a cirurgia ortognática para conseguir melhores resultados e mais precisos, começou a planejar e diagnosticar os casos clínicos utilizando medidas obtidas de grandezas do perfil tegumentar dos pacientes com o auxílio de imagens digitais empregadas em softwares de planejamento, Neste estudo foi proposto aferir as medidas de brasileiros leucodermas de descendência européia e compará-las com as medidas já padronizadas por ARNETT, com o intuito de criar novas medidas para serem seguidas por brasileiros utilizando-se o software Dolphin Imaging 9.0 de prediç̧ão cirúrgica.

Foi utilizado na metodologia radiografias cefalométricas de 60 pacientes com oclusão classe I de Angle e harmonia facial. Todas as radiografias foram digitalizadas e inseridas no software Dolphin 9.0 e um total de 16 pontos de tecido mole e 22 pontos do esqueleto facial foram marcados, seguindo exatamente as marcações da análise de Arnett \& McLaughlin presentes no programa. Os resultados obtidos foram avaliados estatisticamente e mostram que o perfil do brasileiro é quase totalmente diferente do perfil norte-americano, exceção feita a apenas quatro pontos para os homens e outros quatro, para as mulheres. Os brasileiros apresentam uma face menos protruída, um perfil mais convexo e menor proeminência do queixo do que o grupo controle. Os dados obtidos mostram a necessidade de realizar algumas mudanças nas grandezas numéricas para que um perfeito diagnóstico e planejamento possa ser realizado em brasileiros, criando assim o padrão do perfil facial do brasileiro leucoderma de descendência européia.

Palavras-chave: Cirurgia Bucal, Software, Face, Ortodontia. 

1- Introdução 



\section{Introdução}

A ortodontia tem como um dos seus mais importantes objetivos a estética facial. A busca por uma face harmoniosa, além de uma oclusão estética e funcional ideais, norteia de maneira marcante a conduta profissional do século passado até hoje. No decorrer da existência da ciência de Hartley Angle esta expandiu-se, ultrapassou os limites da cavidade bucal, alcançando a nobre tarefa de esculpir as formas faciais.

A face reflete tanto a posição das bases ósseas, maxila e mandíbula, quanto dos arcos dentários. Não é possível segregar a face da oclusão. A movimentação dentária em direção à oclusão normal pode repercutir positivamente no aspecto final somente quando o paciente não apresenta discrepâncias ósseas significantes. Estando estas presentes, temos que aceitar as limitações do tratamento ortodôntico puro. Nestes casos, a ortopedia, durante a fase de crescimento, ou a cirurgia ortognática, no adulto, constituem as únicas terapias que podem atingir o desejo de uma bela face.

Segundo ARNETT ${ }^{11}$, o conhecimento da beleza facial é uma característica nata aos olhos humanos. Entretanto, a definição objetiva dos componentes da beleza é extremamente difícil, pois esta objetividade é solapada pelas preferências pessoais, tendências culturais e pela crença de que a beleza se apresenta de formas diferentes e com características distintas. Para a maioria dos indivíduos isso não é relevante sob o ponto de vista da objetividade; porém, para os cirurgiões e ortodontistas, trata-se de um conceito da mais alta relevância.

PROFFIT $^{106}$ definiu as deformidades dentofaciais como desproporções faciais e dentárias suficientemente extensas a ponto de afetar de maneira significativa a qualidade de vida de um indivíduo e cujo tratamento pode requerer a atuação conjunta da ortodontia e cirurgia ortognática. Essa definição agrupa uma pequena porcentagem da população, que se encontra prejudicada, funcional e/ou socialmente, por componentes faciais ou dentários que se apresentam fora dos conceitos de normalidade.

A estética facial de um paciente pode ser alterada e melhorada pelos cirurgiões dentistas. Mas um diagnóstico incorreto pode significar uma vida inteira de dificuldades físicas e emocionais para o paciente, além de dificuldades potenciais 
na área profissional. Assim, é necessária uma extensa coletânea de informações para a elaboração de um correto plano de tratamento, baseando-se em informações apreendidas de três fontes: (1) na motivação do paciente para o tratamento, (2) no exame clínico facial e intrabucal e (3) na análise dos elementos da documentação inicial, sob a forma de radiografias e modelos.

Com o advento das radiografias cefalométricas, foram desenvolvidos vários tipos de análises cefalométricas na tentativa de definir mais objetivamente os rumos do planejamento ortodôntico.

$\mathrm{Na}$ análise da telerradiografia em norma lateral, as alterações na morfologia óssea e do posicionamento dentário podem induzir o profissional ao diagnóstico de deformidades das estruturas esqueléticas e de relacionamento dentário. A utilização de mensurações esqueléticas da face e do crânio permite a localização dessas deformidades e a quantificação das correções a serem efetuadas. A avaliação cefalométrica é um recurso amplamente utilizado, sendo muitas vezes uma ferramenta indispensável para o plano de tratamento e monitoramento dos procedimentos ortodôntico-cirúrgicos.

Tradicionalmente, os objetivos almejados no tratamento de pacientes com deformidades dentofaciais caracterizam-se por eficiência funcional, harmonia estética e estabilidade dos resultados ${ }^{131}$. Dentre estes, o relacionamento da estética facial com o tratamento ortodôntico foi o foco principal no final do século passado ${ }^{30}$.

Desde algumas décadas, a tendência ortodôntica sofreu nítida transposição de valores. A estética passou a ocupar uma posição de destaque, enfocando o perfil tegumentar inferior. A partir da década de 90, a opinião e a percepção dos pacientes passaram a ser consideradas, contribuindo de maneira significativa para essa mudança de valores, já que a modificação na aparência é considerada o principal motivo para que os indivíduos procurem o tratamento ortodôntico combinado à cirurgia ortognática ${ }^{111}$. Nesse estudo constatou-se que, dos que se dirigem ao consultório do cirurgião ortognático, 71\% são movidos por razões estéticas, enquanto a melhora funcional e dos problemas articulares representam $47 \%$ e $28 \%$, respectivamente.

Apesar da harmonia facial ter assumido um papel de destaque, as formas de avaliação radiográfica utilizadas pela ampla gama dos profissionais não 
acompanharam essa transformação. No tratamento ortodôntico, quando identificado o comprometimento facial, logo responsabilizavam o mau posicionamento das bases ósseas e dos incisivos para explicá-lo. O mesmo ocorrendo na cirurgia ortognática, quando empregadas análises cefalométricas mais tradicionais ${ }^{39,123,124,132}$.

A aplicação da radiografia cefalométrica para estudar o crescimento e o desenvolvimento dos tecidos esqueléticos e dentários despertou a atenção dos profissionais da área sobre o equilíbrio e harmonia dos mesmos ${ }^{20,109}$ A este respeito, $\mathrm{NANDA}^{95}$, em 1995, relata que “a introdução da radiografia cefalométrica no diagnóstico ortodôntico desviou inadvertidamente a atenção dos especialistas da área dos tecidos moles para as estruturas esqueléticas”. Como resultado, enfatizouse mais o equilíbrio dentoesquelético do que as características gerais da face. Pode-se conjeturar que a maioria dos ortodontistas segue a suposição de que, se as estruturas dentárias e esqueléticas estiverem em equilíbrio, as linhas faciais automaticamente fazem o mesmo ${ }^{50}$.

Apesar dos traçados cefalométricos demonstrarem a extensão das displasias esqueléticas, o resultado estético pós-tratamento não depende somente de sua quantificação. Devido à grande variação de espessura e tonicidade dos tecidos moles faciais e peribucais, nem sempre um resultado esqueleticamente favorável apresentase esteticamente aceitável ${ }^{81}$. Vários especialistas ${ }^{24,28,101,144}$ observaram que a espessura do tegumento facial varia, podendo não depender completamente das estruturas dento-esqueléticas. Em alguns casos, inicialmente indicados para cirurgias de redução mandibular, podem ser, na realidade, tratados com protrusão de maxila, ou uma combinação dos dois procedimentos. Apesar do prognatismo mandibular se caracterizar como o componente esquelético diretamente envolvido, seu reflexo no perfil tegumentar muitas vezes é satisfatório ${ }^{115}$, dificultando raciocínio para atribuir ao arcabouço esquelético o comprometimento estético.

Os conceitos do tratamento contemporâneo resultam de transformações recentes. As metas terapêuticas tornaram-se mais amplas, incitando o desenvolvimento de novos instrumentos de diagnóstico. Aos modelos de estudo e à cefalometria somou-se um terceiro método indispensável: a análise facial. É de conhecimento hoje, que os efeitos dos tecidos moles provenientes do tratamento dentofacial oferecem os maiores benefícios funcional e estetico ${ }^{106}$. Mas, somente há 
pouco tempo, o modelo de pensamento do tecido mole, direcionando o tratamento dos problemas dentoesqueléticos, emergiu na ortodontia e na cirurgia ortognática.

Na cirurgia ortognática, o resultado pós-operatório do perfil facial oferece uma predicção com notável precisão. A relação causa-efeito encontra-se bem esclarecida em relação às diferentes técnicas de manipulação dos tecidos. A ausência de sucesso verificada em alguns casos tratados pode ser explicada por enfocar objetivos terapêuticos que não levam em consideração a estrutura tegumentar ${ }^{9,138}$.

ARNETT, com o intuito de obter precisão e objetividade nos planejamentos dos tratamentos cirúrgicos, propôs em 1999 um novo tipo de análise cefalométrica dos tecidos moles ${ }^{9}$, baseada em uma linha vertical. A denominada Linha Vertical Verdadeira, ou True Vertical Line, é uma reta que localizada a frente do rosto do paciente, passa pelo ponto subnasal e por um segundo ponto, localizado $1 \mathrm{~cm}$ (um centímetro) anteriormente à glabela. Utilizando essa linha como referencial, conseguindo quantificar numericamente as grandezas de todo o perfil facial.

As grandezas cefalométricas de tecidos moles criadas por ARNETT $^{9}$ foram obtidas a partir de estudos realizados em pacientes brancos e californianos, estabelecendo os parâmetros normais para esses indivíduos. Contudo, fica claro que para instituir essas grandezas para brasileiros, o estudo deve ser realizado em indivíduos brasileiros. 
2-Revisão de Literatura 



\section{Revisão de Literatura}

A ortodontia teve sempre o papel de pioneira na análise dos tecidos moles, desenvolvendo normas e dados longitudinais importantes também para os cirurgiões bucomaxilofaciais e com o avanço da cirurgia ortognática, o perfil mole e a sua relação com a base óssea ganhou papel de destaque no plano de tratamento tanto do cirurgião como do ortodontista.

A beleza pode ser definida como um estado de harmonia e equilíbrio das emoções faciais, estabelecidas pelas estruturas esqueléticas, pelos dentes e tecidos moles $^{37}$, no entanto sempre sofrendo a influência do meio ambiente.

Em 1865, o britânico Woolnoth classificou o perfil facial em retos, côncavos, e convexos, baseando-se numa linha reta que interceptava os pontos mais protuberantes da glabela e do mento. Para ele, o perfil reto seria o mais agradável esteticamente; o côncavo, contrastando com o convexo, dava à pessoa um ar de maturidade precoce, envelhecendo-a mais rapidamente ${ }^{101,102}$.

ANGLE foi um dos primeiros a propor padrões de beleza na Ortodontia, tendo como modelos, o Apolo de Belvedere, representando a beleza masculina, e a Vênus do Milo, como modelo feminino ${ }^{102}$. Em 1889, quando os instrumentos para diagnóstico utilizados pelos ortodontistas limitavam-se aos modelos de gesso, ANGLE ${ }^{4}$ introduziu uma classificação de oclusão para estudá-los cuidadosamente. Alguns anos mais tarde, em $1907^{5}$, enfatizou a importância dos tecidos moles no tratamento: “A boca é o maior fator em potencial em construir ou relacionar a beleza e o caráter da face, e a forma e beleza da boca dependem amplamente das relações oclusais dos dentes”. Dentre suas observações, passou a advogar que “o melhor equilíbrio, a melhor harmonia e as melhores proporções da boca com outras características, requerem a presença de todos os dentes, e que cada dente ocupe a sua posição correta. Em síntese, uma oclusão normal ${ }^{61,111 ” . ~ D e s t a c a ~ a i n d a ~ q u e, ~}$ apesar do perfil do Apolo de Belvedere representar um ideal de estética e harmonia, é impossível adaptar um único modelo a todas as faces, pois o perfil grego patenteava uma raça pura enquanto que já naquela época a miscigenação era uma constante ${ }^{32,59}$. 
Durante muitos anos, pensava-se que a produção das relações satisfatórias dos dentes e maxilares fosse o único elemento necessário para se conseguir um bom resultado ortodôntico até que a chegada de um progressista ${ }^{32}$ despertou a conscientização de estética facial, que começou a crescer e a ser considerada por muitos ortodontistas um importante fator auxiliar no planejamento ortodôntico. Eminente ortodontista de Chicago e contemporâneo de Angle, Case propagava o pluralismo da estética facial. Em 1921, alegou que “o padrão de beleza não deveria ficar confinado a uma idéia fixa de perfil facial da arte clássica, e sim, deveria permitir ajustes com o tempo... para diferentes tipos de fisionomias que se apresentam para tratamento" 32 . A partir do início do século $\mathrm{XX}$, a cirurgia ortognática se aperfeiçoou e conquistou habilidades, passando a oferecer tratamento satisfatório para os pacientes com discrepâncias esqueléticas acentuadas, salientando que, até então, somente os pacientes com discrepâncias esqueléticas suaves poderiam obter um resultado ortodôntico satisfatório.

Juntamente com desenvolvimento da ortodontia também estava havendo um desenvolvimento das cirurgias bucomaxilofaciais. A cirurgia ortognática originou-se de um campo da cirurgia bucomaxilofacial. Muitas das técnicas existentes para o reposicionamento dos ossos da face tiveram sua origem na Europa, na época das duas Grandes Guerras Mundiais, onde era necessário realizar o tratamento de traumas faciais e ferimentos à bala. A experiência obtida com vítimas de armas de fogo e queimaduras forneceu base e racionalidade para a eleição dos procedimentos cirúrgicos praticados e ensinados na educação médica e odontológica atual.

Da traumatologia se originou o conceito da cirurgia de maxila. O pesquisador francês RENÉ LE FORT ${ }^{77}$ observou as fraturas que acometem a face média após um trauma, na região nasal e malar. Em 1901, descreveu uma linha de fratura horizontal partindo das aberturas piriformes em direção à sutura pterigopalatina. Essas linhas de fratura forneceram orientação para cortes nos procedimentos Le Fort I, II e III. Deste modo, o que era a descrição de uma fratura passou a se denominar osteotomia.

Na correção cirúrgica da discrepância basal antero-posterior, o primeiro procedimento caracterizou-se pela correção do prognatismo mandibular ${ }^{99}$. A terapia consistia em reposicionar cirurgicamente a base óssea envolvida até alcançar um relacionamento intermaxilar adequado, o que significava uma oclusão correta. 
Por muito tempo, a importância conferida ao relacionamento dentário como meta de tratamento permaneceu para um grande número de profissionais, e o critério na decisão do tratamento até anos recentes se baseava na oclusão dentária somente $^{138}$. A integração do aspecto estético no planejamento ortodôntico-cirúrgico das deformidades dentofaciais se desenvolveu gradativamente e de modo conjunto com o aprimoramento das técnicas cirúrgicas e do desenvolvimento de novos materiais.

A radiografia cefalométrica desde sua introdução em 1931 por BROADBENT $^{22}$ nos Estados Unidos, e HOFRATH ${ }^{62}$ na Alemanha, tornou-se uma das mais importantes ferramentas na clínica e pesquisa odontológica. Os ortodontistas encontraram na cefalometria os pontos craniométricos ocultos até então, que permitiram estabelecer as relações entre os dentes e as demais estruturas do complexo craniofacial. Utilizando diferentes pontos de referência, os pesquisadores obtinham medidas angulares e lineares que possibilitavam determinar padrões cefalométricos médios. Esses procedimentos receberam a denominação de análises cefalométricas.

A época em que o ortodontista utilizava apenas os modelos de gesso e as fotografias para seus diagnósticos e avaliações ficou definitivamente no passado. A análise cefalométrica se tornou de uso amplo, não somente em pesquisas, mas também na prática clínica diária. Caracterizou-se, muitas vezes, como uma ferramenta indispensável para o plano de tratamento e monitoramento tanto dos procedimentos cirúrgicos quanto das mudanças no crescimento em pacientes com deformidades dentofaciais. Análises cefalométricas diferentes se desenvolveram desde os primeiros estudos na década de 30 , formando um verdadeiro “mosaico" no diagnóstico cefalométrico ${ }^{54}$.

Depois dos trabalhos de BRODIE ${ }^{23}$, em 1941, muitos autores passaram a utilizar a cefalometria no diagnóstico, buscando analisar os problemas inerentes aos vários tipos encontrados nas três classes de Angle.

Por muitos anos, os trabalhos cefalométricos discorriam principalmente as alterações esqueléticas, decorrentes do tratamento ortodôntico, e pouco se enfatizava as alterações do tecido mole. Essa preferência pode ser explicada pela suposição da época: se os dentes fossem posicionados segundo padrões definidos, os tecidos moles 
faciais automaticamente se acomodariam de forma harmoniosa, e por isso a expressão "cortina de tecido mole" ${ }^{\text {58 }}$.

MARGOLIS $^{85}$, em 1941, preocupado também com o tecido mole da face, desenvolveu um método que conjugava fotografia do paciente com sua telerradiografia, obtendo assim o relacionamento do perfil mole e do perfil duro. Posteriormente, em um estudo sobre a inclinação dos incisivos inferiores ${ }^{86}$, verificou a existência de uma relação entre a inclinação destes dentes e o contorno do terço inferior da face.

A aplicação da radiografia para estudar as características faciais foi registrada pela primeira vez por CARREA ${ }^{31}$, em 1942, que adaptou fio de chumbo mole ao perfil facial e realizou tomadas radiográficas com o objetivo de estudar o prognatismo mandibular.

Estudante da Escola de Angle no final de 1920, TWEED ${ }^{131}$ abandonou o dogma rígido da não-extração, obtendo bons resultados quando exodontias foram utilizadas na terapia ortodôntica. O autor se engajou em desenvolver uma mecânica especializada em fechar espaços, inexistente até então, como protocolo de tratamento. Em 1944, modificou a equação diagnóstica de Angle, unindo a estética facial à necessidade de extração ${ }^{131}$. Seu discriminador diagnóstico, de origem dentoalveolar, era o novo instrumento da cefalometria. Devido tanto à falta de estabilidade das oclusões tratadas quanto às falhas na obtenção de linhas faciais estéticas, defendia que, para obter faces equilibradas, os limites anteriores dos dentes deviam ser determinados pela posição do incisivo inferior. Assim, os incisivos inferiores eram verticalizados sobre o osso basal. Em decorrência desse posicionamento dentário, a aparência se concentrava em torno de um perfil identificado como "tweediano" (dished-in face). TWEED ${ }^{131}$ manteve o ideal de Angle - do perfil abandejado da escultura de Apolo Belvedere - e desenhou seus novos padrões cefalométricos adaptando-os a esse restrito modelo estético.

As publicações de TWEED identificaram um período de desenvolvimento histórico: a Escola Tweediana caracterizou-se pela rigidez de movimentação dos dentes inferiores sobre o osso basal, condicionando-os a uma angulação quase invariável, relacionada ao plano de Frankfort ${ }^{70}$. 
A retração dos incisivos evidenciou a possibilidade de, além de corrigir apinhamentos dentários, ser utilizada para diminuir a protrusão labial e atenuar o perfil. No início dos seus estudos, o autor comenta: "Vocês têm a minha confissão: eu enxergo com um olhar apaixonado uma mandíbula proeminente. Ocasionalmente, embora a natureza tenha criado uma idéia de normal em alguns casos específicos, meu impulso é de sobrepujá-la - senti-la de tal maneira que eu não possa esquecê$l a{ } 131$.

Em 1948, DOWNS ${ }^{39}$ descreveu uma análise cefalométrica sistemática para avaliação dos padrões médios de normalidade dentoesquelético. A análise de Downs é o resultado de três anos de experiência com o método em prática, nos departamentos da Universidade de Illinois, Universidade da Califórnia, Universidade de Northwestern, e Universidade de Indiana. DOWNS previne que seu estudo representa uma média. A variação é inerente. Encontrou desvios marcantes de ambos os lados da média, dizendo serem variações, que precisam ser consideradas ao apreciar o equilíbrio e a harmonia da face. Disse o autor que, "embora haja grande variação entre indivíduos, os possuidores de saúde bucal ótima, equilíbrio funcional e estético, exibem certas características do padrão esquelético em comum”. No entanto, não fez qualquer referência quanto ao perfil tegumentar. Posteriormente, em $1956^{40}$, referiu-se ao tecido mole como "um importante fator para a consideração do perfil” por influir sobre a estética e sobre a dentadura. A seguir, descreveu um método para a obtenção eficiente de imagens dos tecidos duros e moles, simultaneamente, em radiografias cefalométricas.

A introdução da análise de DOWNS estimulou um grande número de pesquisadores e clínicos a desenvolver suas próprias análises. Nesta época houve uma busca febril por métodos de avaliação da arquitetura craniofacial por meio de radiografias. As muitas análises que se seguiram forneciam pontos de referência e medições excessivos, tornando confusas as suas interpretações. Como resultado, informações importantes se perdiam em meio a detalhes minuciosos.

Caminhando em direção oposta, STEINER ${ }^{123,124,125}$ desenvolveu uma análise de utilização eminentemente prática. Para isso, selecionou o que considerou os parâmetros mais significativos e que eram de fácil localização. Elaborou uma análise composta e acreditava que oferecia o máximo de informações clínicas com a menor 
quantidade de medições. A análise de Steiner, desenvolvida na década de 50, pode ser considerada a primeira das análises cefalométricas modernas por dois motivos: 1) exibe as medições de modo a enfatizar não apenas o padrão facial do paciente, mas a sua inter-relação com o padrão de normalidade; 2) e oferece guias específicos para uso das medidas cefalométricas no planejamento do tratamento. $\mathrm{O}$ autor desenvolveu uma técnica que logo se tornou conhecida e utilizada. Para elaborar sua análise, baseou-se em sua grande experiência clínica e também nos trabalhos realizados anteriormente por DOWNS ${ }^{39}$, RIEDEL ${ }^{112}$, HOLDAWAY ${ }^{67}$, WYLIE ${ }^{141}$ e MARGOLIS $^{86}$ entre outros. Utilizando parâmetros sugeridos por HOLDAWAY ${ }^{67}$, nos quais a condição ideal para a localização do incisivo central inferior é que sua coroa estivesse à frente da linha NB e a uma distância igual a do pogônio àquela mesma linha, Steiner obteve planejamentos de correção ortodôntica de grande alcance clínico, que continuam reconhecidos nos dias atuais, mesmo com o amplo desenvolvimento da ortodontia mundial.

Ressaltada a importância estética no diagnóstico ortodôntico do perfil e sua relação com o padrão dento-esquelético, RIEDEL, em 1950, constatou que a relação entre as bases apicais, o grau de convexidade do perfil facial ósseo e a relação dos incisivos com suas respectivas bases ósseas constituem elementos importantes na determinação da estética facial ${ }^{111}$.

Contudo, Tweed sabia que, na prática clínica, a grande maioria dos pacientes apresentava alterações nestes valores estabelecidos pelas análises cefalométricas, cabendo ao ortodontista harmonizar da melhor forma possível o posicionamento dentário à arquitetura craniofacial. Desenvolveu então uma série de diagramas, denominada "tabela de compromissos", nos quais uma modificação na relação maxilomandibular é acompanhada de alterações nos demais ângulos e distâncias dos incisivos, conduzindo o paciente ao equilíbrio.

Como muito de seus alunos alegavam encontrar dificuldades para alcançar os resultados estéticos por ele propostos, TWEED ${ }^{134}$, em 1954, estudando os seus melhores casos, aperfeiçoou sua análise, construindo seu famoso triângulo. Formado pelo plano horizontal de Frankfort, pelo plano mandibular e pelo longo eixo do incisivo inferior, a estética facial seria obtida, seguindo-se os valores normativos preconizados pelo autor. Concluiu afirmando que sua análise pode ser utilizada para 
a elaboração do plano de tratamento da maioria dos pacientes, mas que existem casos em que o exame clínico do perfil do paciente é que deve determinar o tratamento a ser instituído.

Em contraposição à forma simplista de TWEED $^{133}$ de basear seu plano de tratamento na posição do incisivo inferior, WYLIE ${ }^{142}$, em 1955, pesquisou a correlação entre a inclinação dos incisivos inferiores e a alteração decorrente de sua movimentação no perfil tegumentar. O estudo utilizou o material clínico e radiográfico fornecido pelo próprio Tweed, o mesmo no qual sua análise foi baseada. Concluiu que as modificações do perfil por meio ortodôntico dependem não só dos dentes anteriores, mas principalmente do crescimento da mandíbula durante o tratamento. A posição do incisivo era, na verdade, uma conseqüência do tratamento, não determinando o resultado estético final.

Seguindo o mesmo parâmetro de avaliação de Tweed, ou seja, a obtenção da estética facial de acordo com o posicionamento do incisivo inferior, HOLDAWAY ${ }^{63}$, em 1955, estabeleceu o relacionamento de 1:1 entre as distâncias do pogônio e do incisivo inferior em relação à linha NB (P-NB igual a 1-NB). Essa relação, adotada também por Steiner, pode auxiliar na obtenção de um perfil facial harmonioso ao final do tratamento ortodôntico.

HOLDAWAY $^{64}$, em 1956, estudou os ângulos SNA e SNB, introduzidos por Riedel, e as suas diferenças. Entre suas conclusões, declarou que os casos de faces “normais” apresentavam variações na orientação das bases apicais, acompanhadas de variações compensatórias na inclinação dos dentes. Em $1957^{67}$, usando um grupo faces “normais” casos esses originais de Tweed, propôs um método de avaliação simples e objetivo do perfil facial tegumentar. Sugeriu uma linha traçada tangente ao mento mole e ao ponto mais proeminente do lábio superior, e denominou-a de "linha H”. Afirmou que, nos indivíduos com bom perfil facial, essa linha formava um ângulo de $7^{\circ}$ a $9^{\circ}$ com a linha NB dos tecidos duros, quando a relação das bases ósseas fornecida pelo ângulo ANB fosse normal, isto é, em torno de $2^{\circ}$.

Demonstrando interesse pela avaliação do perfil facial tegumentar, MUZJ ${ }^{94}$, em 1956, fez uma análise crítica dos métodos em uso para analisar as variações do perfil e considerou como valores normais os que se aproximam do perfil reto e valores anormais, os que mostravam faces excessivamente côncavas ou convexas. 
STONER \& LINDQUIST ${ }^{126}$, em 1956, realizaram um estudo de radiografias cefalométricas de 57 pacientes tratados por Tweed. Verificaram certas modificações do tecido mole ocorridas durante o tratamento ortodôntico e assinalaram que os incisivos inferiores têm relação fixa com a estética facial, embora possa ser indireta. Os autores concluíram que quatro modificações principais teriam sido responsáveis pela melhoria na aparência dos tecidos moles: 1) uma redução na proeminência dos lábios; 2) uma redução na curvatura do lábio inferior; 3) um aumento da dimensão vertical e 4) certo grau de projeção do mento, para anterior.

De modo similar a Holdaway, RICKETTS ${ }^{108}$, em 1957, considerou que entre os principais objetivos do tratamento ortodôntico estão o equilíbrio e a harmonia da estética facial. O autor preconizou uma linha para análise quantitativa da beleza facial, denominando-a de "plano estético" ou "linha E”, que tangenciando a ponta do nariz e do mento tegumentar, avalia a posição dos lábios. Para sua determinação analisou fotografias de artistas com excelentes perfis, constatando-se que o lábio superior e o inferior situam-se, respectivamente, 4 e $2 \mathrm{~mm}$ posteriormente ao "plano estético”. Observou que os lábios dos jovens do sexo masculino apresentam-se um pouco mais retruídos em relação a essa linha, resultado de uma maior proeminência nasal e mentoniana. Destacou que essas medidas-padrão correspondem a pessoas adultas e que se deve considerar as mudanças durante o crescimento ao se planejar o tratamento ortodôntico.

RIEDEL $^{112}$, em 1957,em seus estudos sobre estética facial afirmou que existem quatro fontes primárias, das quais aceitamos ou obtemos nossos ideais estéticos: 1) o idealismo estético derivado de desenhos, pintura e esculturas antigas ${ }^{5}$ 2) pela influência de homens, tais como Tweed ${ }^{132,133}$, que desenvolveram conceitos de estética baseados na aceitação de agradável ou satisfatório de um rosto no qual a dentadura é estável, com os incisivos em posição ereta, não apinhados; 3) normas cefalométricas angulares e lineares sobre telerradiografias laterais que se baseiam em pessoas de excelente oclusão ${ }^{40,86}$; 4) outra fonte possível baseado nos perfis admirados e desejados como os vistos em astros de cinema, modelos e rainhas de beleza.

Em 1957, um grupo de pesquisadores reuniu-se nos Estados Unidos, em Cleveland, na Fundação Bolton, para discutir o estado atual das radiografias 
cefalométricas. Realizou-se, então, o "Primeiro Simpósio de Cefalometria Radiográfica” cujos principais objetivos foram: (1) estabelecer zonas comuns de crescimento craniofacial, (2) organizar um glossário sobre pontos e planos de referência, diversas medidas e seus valores, (3) estudar o significado de várias medidas obtidas para a interpretação do crescimento craniofacial e (4) discutir a realidade dos padrões de normalidade em uso na técnica das análises cefalométricas. Os resultados deste simpósio foram compilados por KROGMAN \& SASSOUNI ${ }^{73}$, na obra "Syllabus in roentgenographic cephalometry".

Foi posto em destaque, por vários autores entre os quais SASSOUNI ${ }^{117}$, em 1958, que "o clínico pode obter, com a radiografia cefalométrica, o que não obteria tão fácil e precisamente com os outros elementos de diagnóstico. Todavia, ela não poderá orientar exatamente o que fazer, mas, pelo menos, nos acautelará contra o uso de certos tipos de tratamento e, por eliminação, sugere o mais apropriado”.

Nesta mesma fase em que a ortodontia obteve um grande avanço através desta compilação, a área cirúrgica também obteve um grande avanço com a introdução da osteotomia sagital da mandíbula por OBWEGESER ${ }^{99}$ em 1955, que marcou o início da era moderna na cirurgia ortognática. A técnica de divisão do ramo mandibular tornou-se certamente o procedimento cirúrgico mais utilizado em cirurgia ortognática. Várias modificações foram sugeridas no decorrer dos anos, até os dias de hoje, na tentativa de facilitar o procedimento e reduzir suas complicações $^{35,44,68}$, mas os fundamentos técnicos continuam os mesmos. As mudanças incorporadas no protocolo intentavam aumentar a área de contato ósseo, reduzir a quantidade de dissecção dos tecidos e alcançar estabilidade.

Hugo Obwegeser introduziu a abordagem intra-oral, que eliminava as seqüelas causadas por cicatrizes faciais. Destacou-se o desenho da divisão sagital e o método de separação digital do ramo, que representavam um método biologicamente seguro, permitindo, assim, o tratamento da deficiência ou do excesso mandibular. No entanto, a técnica da osteotomia sagital mandibular somente ganhou popularidade no meio científico após sua publicação na literatura americana em 1957, por TRAUNER e OBWEGESER ${ }^{129}$. A indicação da técnica se aplicava aos casos de má oclusão de Classe III e aos pacientes com retrognatismo mandibular severo, merecedores da alcunha "birdface". 
Até 1960, o tratamento das deformidades dentofaciais se concentrava na oclusão dentária. Os ortodontistas dispensavam pouca atenção para a cirurgia e os cirurgiões pouco se interessavam na ortodontia. Com uma base empírica para as técnicas cirúrgicas, realizadas sem o auxílio da ortodontia e praticamente sem intervenção na maxila, não era surpresa que a maioria dos pacientes recebia tratamento comprometido ou sem sucesso ${ }^{17}$.

Historicamente, a oclusão ditava o resultado final da cirurgia. Uma das limitações dessa forma de abordagem era que a posição dos dentes determinava o relacionamento das bases ósseas no momento da cirurgia ${ }^{138}$. Como as compensações dentoalveolares geralmente acompanham as deformidades esqueléticas nos três planos do espaço, o procedimento cirúrgico se tornava limitado. Se somente os dentes forem considerados como critério no plano de tratamento, as suas posições compensadas serão os determinantes do relacionamento das bases ósseas. Como resultado, o perfil facial final não será o desejado. A oclusão dentária não seria uma restrição caso os dentes se relacionassem corretamente às bases ósseas.

Quando o tratamento ortodôntico era combinado com a correção cirúrgica, a intervenção comum era instalar o aparelho, alinhar os dentes em suas respectivas bases ósseas, remover o aparelho ortodôntico, realizar o procedimento cirúrgico e dispensar o paciente. Parte da razão para esse protocolo se explicava pelo desinteresse na melhora que poderia ser obtida com a coordenação mais cuidadosa dos dois tipos de tratamento.

Antes dos anos 60, a correção cirúrgica das deformidades dentofaciais reservava-se quase que exclusivamente aos pacientes com prognatismo mandibular. Devido à anatomia complexa e à possibilidade de insuficiência na vascularização no terço médio, os cirurgiões receavam abordar a maxila mesmo quando o problema maior se localizava nesta região da face.

Nos estudos cefalométricos, LINDQUIST ${ }^{80}$, em 1958, estudou a influência do incisivo inferior no tratamento ortodôntico e na estética facial por meio de fotografias e telerradiografias de perfil, pré e pós-tratamento, sendo as telerradiografias traçadas e sobrepostas. Segundo o autor, para que um método possa efetivamente avaliar o posicionamento dos incisivos inferiores, deve-se considerar a discrepância das bases apicais e a posição do mento ósseo. Ainda contra-indica a 
utilização de medidas angulares, pois estas, principalmente quando consideram o longo eixo dos incisivos, estão sujeitas a grandes alterações, devido à facilidade com que as raízes podem se inclinar para vestibular ou para lingual durante o tratamento ortodôntico. Na opinião do autor, o incisivo inferior tem uma relação definida com a estética facial, talvez indireta, mas muito importante.

Em discussão ao trabalho de Lindquist ${ }^{80}$, WYLIE ${ }^{143}$, em 1959, concordou com a proposição de que o mento deve ser analisado em conjunto com o posicionamento do incisivo inferior, ao avaliar o seu efeito no perfil facial. Pôs-se de acordo também que não se deve basear em apenas um ângulo, extremamente sujeito a alterações no decorrer do tratamento, para planejá-lo integralmente. Entretanto, contestou a idéia de se criar uma fórmula para orientar o posicionamento do incisivo, na determinação da estética facial. Considerando que a preferência estética constitui uma questão pessoal e não contando com meios científicos para afirmar que uma face seja mais bela do que a outra, declarou que, como o julgamento dos artistas e dos ortodontistas é geralmente arbitrário, deve-se considerar também a preferência estética do público.

BURSTONE $^{25}$, em 1959, analisando a relação entre as más oclusões e a desarmonia facial, observou a importância das variações de espessura dos tecidos moles na determinação da harmonia facial; mas advertiu que o tecido mole também pode mascarar uma discrepância dentoesquelética. Baseado numa amostra de adolescentes e adultos jovens, selecionada por artistas, apresentou um método para avaliar a espessura dos tecidos moles radiograficamente. Concluiu que o perfil padrão não pode ser determinado, pois varia de pessoa para pessoa e de um grupo étnico ou raça social para outro.

Existem muitas possíveis explicações para a inadequação da cefalometria. A suposição que a correção da oclusão, baseada em padrões cefalométricos, conduz à correção da estética facial nem sempre é verdadeira e pode, em alguns casos, conduzir a menos do que o desejável do resultado estético ${ }^{65,66,128,139,144}$. O tecido mole que recobre os dentes e osso pode variar tão grandemente que o padrão dentoesquelético pode ser inadequado em avaliar a desarmonia facial ${ }^{24,26,78}$.

RICKETTS $^{109}$, em 1960, submeteu à análise do seu “plano estético” em mil casos antes do tratamento ortodôntico. A maioria dos cirurgiões-dentistas 
consultados considerou que os lábios não devem ultrapassar esta linha para uma boa estética facial. Afirmou que a cefalometria, entre as técnicas disponíveis, é o melhor método para auxiliar o diagnóstico e o plano de tratamento ortodôntico. Não obstante, referindo-se ao uso abusivo da análise cefalométrica, afirmou que " $a$ análise quantitativa da radiografia constitui apenas uma parte de toda sua aplicação clínica; a análise cefalométrica não é uma fórmula para o tratamento, mas sim um método que descreve as condições existentes".

Aperfeiçoando sua análise cefalométrica, STEINER ${ }^{125}$, em 1962, oferece maiores detalhes de sua utilização e explica que considera a distância P-NB muito variável entre os indivíduos e, portanto, uma medida padrão apresentaria um pequeno valor de diagnóstico. O autor preveniu que uma atenção aos tecidos moles da face seria de vital importância para uma avaliação dos problemas ortodônticos. Após considerar os diferentes métodos de análise dos tecidos moles, lembrou da necessidade dos mesmos serem testados, a fim de que um deles fosse adotado. Sugeriu uma linha que, partindo do pogônio mole, tangencia ambos os lábios, passando pelo ponto "S" do nariz, denominando-a "linha S". Essa linha ofereceria uma rápida avaliação visual dos tecidos moles da face e em jovens leucodermas com faces harmoniosas, ambos os lábios deveriam tocar essa linha.

A população melanoderma não tinha uma literatura ortodôntica pródiga sobre os estudos de estética facial. O tratamento dessa raça limitava-se à utilização de padrões de leucodermas, ou ao conceito pessoal de beleza do ortodontista. Mas ainda em 1937, WUERPEL ${ }^{140}$ recomendava tratar a má oclusão respeitando o tipo facial do grupo racial do paciente.

Realizando um estudo retrospectivo da arte e das formas faciais, desde a cultura egípcia, passando pelos gregos e romanos, até sua época, HAMBLETON ${ }^{59}$, em 1964, verificou que o conceito de beleza varia de acordo com a época. Comprovou que havia uma predileção pelo perfil facial reto, aceito pela mídia jornais, revistas e filmes. Contudo, afirmou que esse tipo de perfil não se adapta a todos os indivíduos e, portanto, as faces não podem ser estereotipadas. Estabeleceu que qualquer análise prévia ao tratamento deve considerar a idade e os fatores de crescimento inerentes a cada pessoa. 
BURSTONE ${ }^{24,25}$, em 1958 e 1959, apresentou idéias de que corrigir a discrepância dentária não necessariamente tratará o desequilíbrio facial e pode mesmo causar desarmonias faciais. DROBOCHY, SMITH ${ }^{41}$, em 1989 relacionaram os dados de 160 pacientes ortodônticos submetidos a extrações de quatro pré-molares e concluíram que as principais mudanças foram um aumento do ângulo nasolabial e retração dos lábios superior e inferior à linha E. Ao se comparar as mudanças do perfil com valores representativos normalidade, constatou-se que as extrações não resultaram perfil achatado pois apenas $10 \%$ a $15 \%$ dos casos poderiam ser definidos como excessivamente achatados (dished-in) após o tratamento.

Essa tendência teve o seu início após a introdução da cefalometria radiológica em 1937, quando BROADBENT ${ }^{22}$ deu ênfase à nova técnica, assinalando que uma de suas vantagens sobre a antropometria era o fato de não atuar sobre a superfície dos tecidos moles, de espessura desconhecida.

Seguindo o pensamento de Broadbent, GRABER ${ }^{55}$, em 1956, afirmou que há uma tendência de simplificação da interpretação dos dados cefalométricos, comparando-os a um grupo conhecido por "valores normais". No entanto um paciente pode apresentar valores que não estão dentro destes valores normais e ainda assim apresenta harmonia facial ou um discreto problema facial, apesar de não estar dentro da "norma".

HAUSSER $^{60}$, no mesmo ano, durante uma investigação das relações entre a parte mole da face e o perfil duro, examinou radiograficamente, 50 crianças com “oclusão normal”. Constatou que o lábio inferior não era tão proeminente como o superior, sendo que a média de inclinação dos meninos era mais acentuada que nas meninas. Concluiu que o contorno dos tecidos moles depende da consistência dos mesmos e da estrutura do perfil duro.

Em 1957, numa tentativa de associar medidas cefalométricas utilizadas até então com a estética, POULTON ${ }^{105}$ testou algumas medidas propostas por Steiner e Downs em pacientes jovens, de ambos os sexos, portadores de oclusão normal e bom perfil facial. Para isso, utilizou fotografias laterais da face, que foram oferecidas a dez membros do corpo ortodôntico da Universidade da Califórnia, para apreciação de ordem estética. Cada um deles colocou as fotografias em ordem decrescente, segundo a sua preferência. Contudo, somente as oito primeiras fotografias e as oito 
últimas de cada sexo, foram aproveitadas na pesquisa, e nas radiografias cefalométricas correspondentes foram medidos ângulos recomendados por diversas análises. Os ângulos preferidos pelo autor, para estudos de correlação em estética facial de acordo com os resultados deste estudo são SNA, o ângulo de convexidade NAP, a relação incisivo inferior com o plano mandibular.

No mesmo ano, DAUGAARD-JENSEN ${ }^{36}$ narrou a grande controvérsia que sempre houve entre os ortodontistas, para a escolha de um perfil agradável, pois gosto não se discute. Expressando seu conceito de beleza, apresentou um grupo de faces que, sob seu ponto de vista, revelavam algo em comum: uma área suave e uniforme ao redor do canto da boca e do lábio inferior; quanto mais suave for esta parte mais os olhos dominarão a face e mais refinada ela parecerá. Para a autora, as evidências clínicas demonstram que Tweed tem razão ao mencionar que a posição do incisivo inferior influi decisivamente na estética facial, porém, acredita que não deveríamos determinar ângulos ou dimensões médias para a inclinação dos incisivos inferiores, pois a variação do padrão esquelético é grande. Relatou que, devido ao desconhecimento da relação entre os tecidos moles e duros, muitas vezes o resultado ortodôntico, com respeito à aparência facial, não foi o previsto. Afirmou que o progresso na técnica de tratamento deveria ser acompanhado de igual progresso no setor do estudo da estética facial.

Em 1959, NEGER ${ }^{96}$ realizou estudos em 48 indivíduos de nove a dezesseis anos com oclusão normal, e introduziu um método de avaliar o perfil mole de uma maneira quantitativa, sobre uma fotografia de perfil ou radiografia cefalométrica. Os lábios superior e inferior e o mento foram relacionados com o ponto násio do perfil mole e também com o plano horizontal de Frankfort através de seis ângulos diferentes. Concluiu que o perfil reto não é necessariamente acompanhado de oclusão normal, devido à grande miscigenação existente na população americana; ainda, as informações obtidas por análises exclusivamente dentoesqueléticas não asseguram uma avaliação precisa das possíveis alterações do tecido tegumentar provocadas pelo crescimento ou tratamento ortodôntico, pois a mudança do perfil mole nem sempre se relaciona com a dos dentes. Este trabalho mostrou uma maneira simples e prática de avaliar o perfil dos pacientes e sugeriu ainda, que o diagnóstico 
deve ser muito bem elaborado e explanado ao paciente, pois mesmo os portadores de oclusão normal podem apresentar deficiência na região do mento.

BOWKER; MEREDITH ${ }^{21}$, em 1959, fizeram um estudo comparativo de medidas lineares a partir de cinco pontos do perfil mole em relação com a linha násio pogônio do perfil ósseo. O objetivo principal deste estudo foi o de estabelecer um método métrico para descrever o perfil mole da face.

Em 1960, SALZMANN"116, em um artigo após a realização do "Second Cephalometric Workshop”, repetiu os três componentes necessários para a análise cefalométrica propostos por DOWNS ${ }^{39}$, e, ao referir-se à análise do perfil, considerou-a principalmente, um cálculo de adaptação dos tecidos moles ao perfil ósseo. Indicou que certas medidas do esqueleto podiam ser influenciadas pelos tecidos moles e reconheceu que a análise do perfil estaria distante de ser estabelecida.

LUSTERMAN $^{82}$, em 1963, analisou diferentes tipos raciais, empregando medidas dentoesqueléticas, e medidas referentes à espessura, altura e inclinação do perfil mole. Em uma de suas conclusões, assinalou que a mais importante característica dizia respeito aos tecidos moles, nos quais foram considerados o volume e a inclinação dos lábios. Salientou, ainda, que se deve ter em mente as diferenças entre as raças para individualizar cada caso a ser tratado.

Devido à grande quantidade de estudos demonstrando as dificuldades que os ortodontistas principalmente os mais inexperientes possuíam em visualizar a estética facial, MERRIFIELD ${ }^{92}$ descreveu, em 1966, uma técnica para avaliar o perfil facial do terço inferior da face. Para tanto, realizou um estudo no qual recorreu a métodos peculiares para medidas de espessura do lábio superior, do lábio inferior e do mento. Traçou uma linha tangenciando o mento tegumentar e o lábio com maior protrusão, estendendo-a até o plano horizontal de Frankfort para formar o ângulo "Z” ou "linha do perfil”, que expressa a quantidade de protrusão labial. Valeu-se de 120 telerradiografias divididas em três grupos: 40 de oclusão normal, 40 de casos ortodônticos tratados por TWEED e 40 de casos ortodônticos tratados por ele próprio. Como resultado, observou que o ângulo “Z” situa-se em torno de $80^{\circ}$ para os adultos com oclusão normal. Entre suas afirmações, destacam-se: 1) a espessura total do mento é de máxima importância na avaliação do perfil e deve ser igual ao pouco 
maior que a espessura do lábio superior; 2) a posição dos lábios pode ser julgada com precisão pela sua relação com a linha do perfil, devendo o lábio superior estar tangente a esta linha e o inferior, tangente ou ligeiramente posterior. Estabeleceu ainda que, durante a análise facial, o mento deve ser avaliado tanto em seu componente esquelético quanto à espessura de seus tecidos moles, pois ambos apresentam grande variabilidade. Assim, por exemplo, seria possível detectar uma proporção inadequada de cada um desses elementos isoladamente, porém, desde que ocorram compensações entre eles, o perfil facial não sofrerá prejuízos.

Reconhecendo a grande importância da análise dos lábios com relação ao planejamento da terapia ortodôntica, BURSTONE ${ }^{26}$, em 1967, propôs uma linha unindo o ponto subnasal ao pogônio tegumentar, denominada "linha B", para a avaliação estética da face, permitindo a mensuração da protrusão ou retrusão dos lábios em relação a essa linha. Até então o assunto era mais difundido na literatura britânica, mostrando a importância da avaliação dos lábios, em repouso, ao analisar os casos. Essa linha foi selecionada por apresentar uma variação muito pequena no contexto geral da face e os lábios superior e inferior encontram-se anteriormente a ela, respectivamente, $3,5 \mathrm{~mm}$ e $2,2 \mathrm{~mm}$. Acrescentou ainda que algumas desarmonias faciais podem ser observadas mesmo na ausência de discrepâncias dentoesqueléticas e, nesses casos, talvez se encontrem associadas às características labiais. Com o auxílio dos parâmetros preconizados nesse estudo essas desarmonias poderiam ser mais facilmente detectadas. Acrescentou ainda, que as diversas morfologias faciais originam-se pelas diferentes posturas, espessuras e comprimentos labiais, além da amplitude dos padrões esqueléticos. Consequentemente, os padrões ideais preconizados devem ser utilizados com cautela.

Ao aplicar o seu plano estético, RICKETTS ${ }^{110}$, em 1968, citou nove fatores que deveriam ser considerados na análise do perfil. Um deles afirmava que os lábios poderiam ser influenciados pelos dentes, ou que, inversamente, os dentes poderiam ser influenciados pelos lábios. A partir de dados obtidos de outras publicações e experiências comuns com o público, leigos e alguns artistas, observou que os adultos faziam objeção quanto aos lábios que passavam além do plano "E”; entretanto a proeminência da boca ou lábios cheios marca a juventude, enquanto que bocas com lábios planos sugerem mais idade. 
Utilizando as análises de Downs, Steiner e Ricketts, ALTEMUS² , em 1968 estudou as variações existentes entre indivíduos leucodermas, melanodermas, xantodermas, índios navajos e aborígines australianos. Concluiu afirmando que a utilização de normas e padrões concebidos e desenvolvidos a partir do conceito de beleza de uma raça é imprópria para o tratamento de um paciente de uma raça diferente.

WILLIAMS $^{137}$, em 1969, diz que o que tornou tão valiosa a contribuição de TWEED para a análise cefalométrica foi a sugestão de que existia uma correlação entre o ângulo do incisivo inferior e tecido mole. Defendeu o valor da linha AP como critério para avaliação do equilíbrio dos lábios. De acordo com este autor, quando a borda incisal do incisivo inferior coincidir ou se posicionar levemente para trás da linha AP, esta posição estaria correlacionada com um contorno labial harmonioso.

Considerando que no Brasil coexistem diversas raças, MACHADO FILHO ${ }^{83}$, em 1969, examinou 69 brasileiros do sexo masculino, de diversas origens, com o intuito de relacionar os tecidos moles com os duros. Conclui que não se pode padronizar as relações dentoesqueléticas com perfil tegumentar quando não se associa cada paciente com sua origem racial.

PECK; PECK ${ }^{102}$, em 1970, comentam que termos puramente estéticos, como “harmonia, equilíbrio e proporção”, são usados muitas vezes para descrever padrões esqueléticos em estudos cefalométricos, existe uma tendência prevalente entre ortodontistas, de desenvolver em nossas mentes um conceito de estética facial “interna”, quer dizer, com deficiência em consideração direta das relações de tecidos moles.

Apesar de não serem os primeiros autores a indagar sobre a relevância da estética facial para a ortodontia, mas sim uns dos mais citados para fundamentar afirmações a respeito, são HARVEY e SHELDON PECK ${ }^{102}$. Baseando-se em investigações realizadas no campo da sociologia e psicologia, procuraram demonstrar a semelhança do gosto popular na área da preferência estética. Estudaram os padrões faciais de 52 adultos jovens considerados por um segmento da população como tendo estética facial agradável. A amostra consistia inteiramente de modelos profissionais, vencedores de concursos de beleza e artistas, notáveis pela atratividade facial. A rara natureza da amostra tornou esse estudo diferenciado. As radiografias 
cefalométricas dos indivíduos foram analisadas de acordo com as análises de Steiner, Downs e Margolis. Os resultados indicaram que "o público em geral apresenta admiração maior pelo padrão dentofacial mais protrusivo e mais cheio do que permitiriam os padrões cefalométricos rotineiros”. Observaram ainda que a noção de estética varia de uma cultura para outra e sofre influência dos meios de comunicação, como a televisão, o cinema, os jornais e as revistas, que mostram faces estereotipadas. Portanto, seria muito difícil que alguns membros da sociedade, inclusive os próprios ortodontistas, pudessem isolar-se completamente dessas influências onipresentes. As fotografias de perfil facial dos indivíduos confirmaram que a diversidade da forma facial se encaixa nos conceitos de estética agradável das pessoas em geral. Esse estudo revelador, acoplado a outros, ajudou a levar a ortodontia para a gama ampliada e realista da estética facial aceitável de hoje, e para um equilíbrio mais racional entre os tratamentos com e sem extração.

Até esse momento, todas as pesquisas se desenvolveram com amostras de indivíduos com “oclusão normal” e perfil facial agradável. Em abordagem diferente, COX; VAN DER LINDEN ${ }^{33}$, em 1971, selecionaram aleatoriamente indivíduos de ambos os gêneros, tanto com oclusão normal como associados à má oclusão. Estudaram a harmonia facial por meio de fotografias, para diferenciar entre aparências faciais boas e desagradáveis, em jovens de 18 a 20 anos de idade. As fotografias da silhueta foram avaliadas por dez ortodontistas e dez leigos. Verificouse grande concordância de opinião entre os examinadores. As análises de tecidos moles e medidas esqueléticas pela cefalometria radiográfica mostraram que, em ambos os gêneros, as pessoas com equilíbrio pobre possuem face mais convexa que as com equilíbrio facial bom. Os grupos de homens com equilíbrio pobre mostram posição mais anterior dos incisivos superiores e inferiores. Em destaque, verificou-se que numerosas faces com boa aparência ou equilíbrio facial se encontravam associadas com más oclusões. Este estudo mostrou que a boa estética facial pode ser associada com más oclusões, assim como às oclusões normais.

Ao avaliar alguns pacientes tratados ortodonticamente apresentando um perfil facial harmonioso e uma oclusão dentária aceitável, SERVOSS ${ }^{120}$, em 1973, verificou que os resultados obtidos não coincidiam com os padrões cefalométricos 
propostos por Steiner. No entanto, ressaltou que a análise de Steiner é um bom guia para direcionar o tratamento.

WORMS et al. ${ }^{138}$, em 1976, afirmaram que os indivíduos com um relacionamento ântero-posterior esquelético inadequado e/ou dentário podem apresentar contornos do tecido mole normais ou próximos da normalidade. Por outro lado, pacientes com relação dentária e esquelética normais podem apresentar os contornos dos tecidos moles da face anormais. Eles concluíram que os contornos de tecido mole podem ser melhorados corrigindo as relações esqueléticas e/ou dentárias. Reconheceram, ainda, a importância dos tecidos moles para as análises das deformidades dento-faciais.

Para BURSTONE ${ }^{27}$, em 1978, a avaliação cefalométrica é somente um passo no diagnóstico e plano do tratamento. Ela fornece ao clínico discernimento da natureza quantitativa da displasia dentoesqueléticas. Se a cirurgia é planejada para produzir mudanças cefalométricas que fazem a face se aproximar dos valores normativos, usualmente uma face mais típica e desejável é produzida. É um equívoco, entretanto, tratar em direção a um padrão que evita outras considerações. Os tecidos moles podem e fazem "mascarar” os ossos e dentes adjacentes; desse modo o clínico deve compensar para essa variação ${ }^{25,26,52}$

Baseando-se nas afirmações de Burstone, Downs e Peck \& Peck de que o perfil facial varia entre os diferentes grupos étnicos, FREITAS ${ }^{50}$, em 1978, desenvolveu um estudo cefalométrico em jovens leucodermas brasileiros. Comparou os perfis com as linhas preconizadas por Ricketts, Steiner, Holdaway, Burstone e Merrifield, avaliando qual ou quais destes métodos seriam mais eficientes na análise estética de brasileiros. Concluiu que as análises de Burstone e de Steiner foram as que melhor se relacionaram com os perfis faciais da amostra brasileira sob investigação. O sexo masculino, na faixa etária analisada, ainda apresentava bom potencial de crescimento. Ao comparar as medidas obtidas em sua amostra às propostas por Holdaway, constatou que o perfil facial tegumentar de adolescentes brasileiros do sexo masculino denota maior convexidade em relação ao dos norteamericanos. Quanto à análise de Ricketts, observou que seus valores podem ser aplicados apenas para as jovens do sexo feminino. 
Para verificar a aplicabilidade dos valores cefalométricos das análises de Downs, Tweed, Steiner e Alabama para os adolescentes brasileiros, MARTINS ${ }^{88}$, em 1979, utilizou uma amostra de 85 telerradiografias em norma lateral. Ao analisar as medidas pelo padrão esquelético de Steiner, o autor verificou que, surpreendentemente, as medidas do padrão esquelético da amostra de Bauru apresentaram médias similares às de Steiner e, quando submetidas ao teste " $\mathrm{t}$ " de Student, apresentaram-se não significantes, isto é, dignos de confiança e utilizáveis para a amostra paulista. Concluiu que os leucodermas brasileiros de origem mediterrânea podem apresentar o mesmo padrão esquelético dos leucodermas americanos de origem nórdica. Conseqüentemente, as medidas esqueléticas preconizadas por Steiner podem ser utilizadas para o diagnóstico e planejamento de tratamento dos jovens brasileiros com a mesma ascendência da amostra paulista. Quanto ao padrão dentário, o estudo demonstrou, sem muita surpresa, resultados díspares. O posicionamento dos incisivos superiores e inferiores, quando medidos angular e linearmente, evidenciaram que os jovens brasileiros apresentam uma protrusão mais acentuada quando comparada aos valores preconizados para os americanos.

A década de 70 para a cirurgia como na ortodontia também foi de grandes avanços, graças ao progresso muito rápido promovido por BELL ${ }^{14}$ e EPKER \& WOLFORD $^{43}$ da técnica de osteotomia Le Fort I, que permitia reposicionar a maxila nos três planos do espaço. Apesar não serem os introdutores do procedimento, seus trabalhos se destacaram por apresentar evidências científicas por meio de pesquisas clínicas, que demonstraram resultados positivos no emprego da cirurgia maxilar.

Em sua introdução, o trabalho de BELL ${ }^{14}$ menciona as dificuldades e as incertezas vivenciadas pelos cirurgiões até o momento. O pesquisador relatou que os inovadores da operação experimentaram a inabilidade operacional em reposicionar a maxila e o receio em imobilizá-la por completo, ou a recomendação da cirurgia realizada em duas fases devido à precaução em comprometer a vascularização dos tecidos. A apreensão diante da incerteza em traumatizar as estruturas vasculares, com possível desvitalização óssea e dos dentes, foi a principal objeção da técnica.

Neste mesmo ano, um estudo de microcirculação óssea em macacos Rhesus ${ }^{15}$ demonstrou a possibilidade de imobilizar a maxila sem comprometer a 
vascularização e a reparação óssea, e desse modo, estabeleceram-se as bases biológicas para o procedimento. Também, os princípios cirúrgicos divulgados por BELL $^{14}$ e EPKER \& WOLFORD ${ }^{43}$ deram grande impulso à osteotomia Le Fort I, até então praticada por poucos, desmistificando a técnica e tornando-a tão conhecida quanto a osteotomia de mandíbula.

Destacam-se nos artigos as ferramentas para o diagnóstico do comprometimento maxilar e a indicação da cirurgia Le Fort I. Os autores enfatizaram o exame facial clínico do paciente. “Um ângulo nasolabial obtuso é provavelmente o critério de diagnóstico mais importante para o avanço da maxila”, disse BELL ${ }^{14}$. Para EPKER \& WOLFORD ${ }^{43}$ : “Nós devemos confiar mais na avaliação clínica da face do que na avaliação cefalométrica para diagnosticar muitas deformidades no terço médio”, e explicam: "Muitos indivíduos com deformidades no terço médio da face possuem bases cranianas alteradas. Desse modo, o diagnóstico cefalométrico pode não oferecer confiança”.

Pela primeira vez, o ortodontista e o cirurgião bucomaxilofacial têm a possibilidade de planejar o tratamento onde o problema se localiza. Uma deformidade esquelética no terço médio da face pode agora ser corrigida com o alinhamento cirúrgico da maxila e uma deformidade mandibular, pela cirurgia na mandíbula. Previamente ao desenvolvimento da osteotomia na maxila, o tratamento disponível para as deformidades dentoesqueléticas era de alguma forma restrito aos limitados procedimentos cirúrgicos da época. Apesar de ter a possibilidade de se identificar a região afetada da face, pouco poderia ser feito para corrigir o problema. Com a evolução da osteotomia Le Fort I, as habilidades cirúrgicas se aperfeiçoaram e os locais específicos afetados pela deformidade tornaram-se passíveis de serem tratados, como ocorre nos casos de má oclusão de Classe III.

Em 1995 foram publicados os resultados de um estudo mostrando as tendências no tratamento cirúrgico da Classe III. Conduzida por BAILEY et al. ${ }^{13}$, a pesquisa revisou as abordagens de tratamento realizadas de 1978 a 1992, na Universidade da Carolina do Norte. Até 1985, aproximadamente metade dos pacientes se submetia a redução isolada de mandíbula e somente $15 \%$, ao avanço de maxila. A explicação residia no fato de que, até essa época, a má oclusão de Classe III de Angle e o prognatismo mandibular eram considerados sinônimos, o que 
caracterizava a mandíbula como o componente esquelético diretamente envolvido na anomalia craniofacial ${ }^{136}$. Essa constatação, associada à técnica da osteotomia de mandíbula ter sido primeiramente introduzida, fez com que a redução mandibular fosse o tratamento de eleição para a Classe III. No entanto, o surgimento de pesquisas que sugeriam vários tipos de padrões de combinação esquelética desta má oclusão $^{72}$ e o desenvolvimento da osteotomia Le Fort I tornaram possível o tratamento combinado de maxila e mandíbula. De 1985 a 1990, a quantidade de avanço isolado de maxila praticamente dobrou, e a cirurgia combinada foi o procedimento realizado em $50 \%$ do total da amostra. Nos dois últimos anos da pesquisa, a diminuição da aplicação da redução isolada de mandíbula continuou, a ponto de somente $9 \%$ dos pacientes Classe III serem submetidos a esse procedimento.

A adição do exame facial teve papel fundamental nessa mudança no plano de tratamento. Em algumas situações clínicas, nas quais o paciente apresenta uma linha mento-pescoço satisfatória, evidenciando uma mandíbula de tamanho normal ou até mesmo revelando-se grande na cefalometria para as normas populacionais, o avanço de maxila oferece uma opção de tratamento bastante atraente. O recuo de mandíbula, muitas vezes, pode originar mudanças nem sempre desejáveis como o acúmulo de tecido mole na região do pescoço ${ }^{13,38}$. Como demonstrado por WORMS ${ }^{138}$, pacientes com padrão facial Classe III que possuem a linha mento-pescoço pequena e ângulo terço inferior-pescoço obtuso ${ }^{78}$, comumente não devem ser submetidos à redução de mandíbula. Na atualidade, a osteotomia para redução de mandíbula oferece grande vantagem no tratamento da assimetria mandibular, sendo esta a sua principal indicação, e para os casos não tão freqüentes de prognatismo verdadeiro ${ }^{115}$.

Até mesmo em pacientes com má oclusão de Classe III, cujas informações obtidas pela cefalometria sugerem prognatismo mandibular verdadeiro, o avanço isolado de maxila pode oferecer resultados satisfatórios ${ }^{115}$. A explicação para o bom resultado estético pode residir na harmonia sagital e vertical maxilomandibular, e seu reflexo no tecido mole. Para alguns autores ${ }^{11,13,34,115}$, obter a proporção entre as estruturas torna-se fundamental para atingir bons resultados.

Ainda nos anos 70, a maior porcentagem de correção cirúrgica dos problemas que envolviam a maxila e a mandíbula no mesmo paciente se realizava em estágios 
distintos $^{57}$. Essa forma de atuação se explica pela complexidade do planejamento pré-cirúrgico da época, pelas dificuldades técnicas dos procedimentos e pelo tempo despedido para completar cada procedimento. O conhecimento prático e o refinamento das técnicas cirúrgicas permitiram maior benefício aos pacientes e à especialidade de cirurgia bucomaxilofacial. Tornou-se comum a associação de diferentes procedimentos executados de maneira simultânea. Na década seguinte, o progresso do conhecimento prático tornou possível reposicionar um ou ambos maxilares, movimentar o mento nos três planos do espaço e reposicionar os segmentos dentoalveolares cirurgicamente, como desejado.

No entanto, apesar dos benefícios oferecidos com o tratamento ortodônticocirúrgico, a resistência por parte do paciente era grande. Uma das principais causas da não aceitação do tratamento era a necessidade do paciente de se submeter a um período pós-cirúrgico de imobilização maxilomandibular com duração de seis a oito semanas. Este período se destinava à consolidação das áreas de osteotomia e se justificava pela precariedade das osteossínteses feitas com fios de aço inoxidável. Além disso, o período de internação era longo, entre uma e duas semanas, dependendo se a intervenção cirúrgica fosse isolada - em apenas uma das bases ósseas, ou maxilomandibular ${ }^{56}$.

A imobilização maxilomandibular era associada a uma grande perda de peso com debilidade física prolongada e um longo período de convalescença, que implicava em faltas ao trabalho por um período de tempo considerável.

Com sua introdução por SPIESSL ${ }^{122}$, em 1974, para a osteotomia sagital de mandíbula e utilizada com maior freqüência em nosso meio a partir de 1990, a fixação interna rígida com placas e parafusos de titânio substituiu em grande extensão o bloqueio intermaxilar e a fixação com fios de aço inoxidável.

Com a possibilidade da fixação interna rígida, o paciente desobrigou-se da necessidade de imobilização intermaxilar pós-operatória ou passou a executá-la por período curto de tempo. As miniplacas e parafusos de titânio asseguram um adequado contato ósseo e permitem a abertura bucal após a cirurgia. No caso do bloqueio intermaxilar, o risco pós-operatório imediato de bronco-aspiração por refluxo gástrico era o maior fator complicador, além das dificuldades na dieta e de higiene bucal. O tempo médio de internação pós-operatória tornou-se 
significativamente reduzido, além de possibilitar redução mais rápida do edema pósoperatório e melhor estabilidade dos segmentos ${ }^{106}$.

Algumas desvantagens podem ser relacionadas com a utilização da fixação interna rígida: exigência de maior habilidade técnica - as miniplacas devem se adaptar passivamente nas áreas de contato ósseo-, aumento dos custos - devido à tecnologia necessária para a confecção das miniplacas e parafusos-, e possível distúrbio neurosensorial com a compressão dos segmentos ósseos. Entretanto, as vantagens oferecidas ao paciente mostraram-se tão importantes a ponto da fixação interna rígida tornar-se o procedimento padrão nos centros cirúrgicos. A evolução da cirurgia ortognática como especialidade e a sua difusão tiveram como principal fator a adoção da fixação interna rígida nos procedimentos.

O plano de tratamento cirúrgico assumiu uma nova hierarquia. A promoção de melhor cicatrização óssea, menor índice de recidiva e associação de um melhor entendimento dos padrões típicos das mudanças pós-cirúrgicas tornaram o resultado cirúrgico mais estável e previsível. O tratamento cirúrgico e ortodôntico combinado pode agora ser planejado em problemas dentofaciais severos de qualquer tipo. A especialidade se desenvolveu amplamente nas últimas três décadas do século XX. Até este período, havia meios limitados para avaliar o problema e, portanto, de ajudar a solucionar a situação.

Em artigo intitulado “Cefalometria para cirurgia ortognática”, BURSTONE; JAMES; LEGAN ${ }^{27}$, em 1978, desenvolveram uma análise cefalométrica especialmente projetada para o paciente que apresenta necessidades de tratamento ortodôntico-cirúrgicos. Devido ao seu caráter linear, as mensurações podem ser facilmente aplicadas em traçados predictivos e estudo dos modelos montados em articulador e podem ser utilizadas como uma base para o diagnóstico inicial e para a avaliação da estabilidade pós-tratamento. No entanto, neste artigo, os autores não fizeram referência à avaliação dos tecidos moles no planejamento cirúrgico.

Então, em 1980, LEGAN \& BURSTONE ${ }^{78}$ publicaram um artigo complementando o anterior, mas enfatizando a análise do tecido mole. Deixam claro que a análise de tecidos esqueléticos, apesar de indicar a natureza da discrepância intermaxilar, mostra-se incompleta quanto ao fornecimento de dados sobre a forma e proporções faciais do paciente. BURSTONE ${ }^{24}$ já havia desenvolvido, em 1858, uma análise dos 
tecidos moles direcionada ao plano de tratamento ortodôntico. Com o desenvolvimento e maior interesse dos clínicos por cirurgia ortognática, a análise foi reduzida às medições mais relevantes e acrescida de outras consideradas importantes para o tratamento dos pacientes cirúrgicos. Então, uma análise cefalométrica dos tecidos moles designada para pacientes que requerem tratamento ortodônticocirúrgico foi desenvolvida para complementar a análise dentoesquelética previamente relatada. Para isso, estudaram a proporcionalidade facial analisando telerradiografias de 40 adultos jovens, sendo 20 do sexo masculino e 20 do feminino. Em conclusão, os autores afirmaram que se o objetivo principal da cirurgia ortognática é a melhora da estética facial, a análise do tecido mole torna-se soberana no plano de tratamento.

Com uma amostra de 56 telerradiografias de adultos jovens, leucodermas de ambos os sexos, portadores relacionamento ósseo e dentário harmônicos, sem tratamento ortodôntico prévio e proporções faciais equilibradas, SCHEIDEMAN et $\mathrm{al}^{118}$ propuseram estabelecer valores considerados normais para os tecidos tegumentar, ósseo e dentário em uma população adulta e determinaram uma série de valores cefalométricos para utilização no diagnóstico e planejamento de cirurgias de pacientes portadores de desarmonias dentoesqueléticas.

HOLDAWAY ${ }^{65}$, em 1983, demonstrou a inadequação do uso exclusivo de análises do tecido esquelético no planejamento ortodôntico sem a merecida consideração ao tecido mole. Reafirmou a utilização da sua linha de referência facial, a linha "H”, ao propor uma análise cefalométrica do tecido mole. A análise resultou da experiência clínica do mesmo, que a aplicou durante muitos anos em sua prática diária antes de publicá-la. Como em outras análises pré-existentes, ângulos e medidas lineares foram estudados e relacionados com medidas do esqueleto facial, com o intuito de correlacionar, mas não excluir, a análise dos tecidos duros. Dentre as medições, destacam-se o posicionamento do mento tegumentar e a projeção do lábio superior no perfil facial. Torna-se possível, ainda, avaliar a proeminência do nariz, envolvendo todas as partes que compõem a face do indivíduo. Demonstrou que a utilização de análises baseadas nos tecidos duros leva ao insucesso do tratamento quanto à estética por não contemplarem as mudanças do crescimento e da espessura dos tecidos moles que recobrem a face. 
No ano seguinte, HOLDAWAY ${ }^{66}$ descreveu o método OVT, ou “Objetivo Visualizado de Tratamento”. Em essência, o método consiste na predição do crescimento do complexo craniofacial. O autor destaca a importância primária da estética facial no planejamento. Inicialmente deve-se estabelecer o perfil do tecido mole ideal do paciente para, só em seguida, computar-se os movimentos dentários necessários para atingir as relações ideais de equilíbrio e harmonia faciais visualizadas no início.

A avaliação cefalométrica não é a ferramenta primária de diagnóstico. Consequentemente, o objetivo primário do tratamento não é fazer as medidas cefalométricas do paciente "normais”, mas sim fazer a aparência facial mais normal. Certamente na maioria dos casos isso faz as medidas cefalométricas mais normais, mas em algumas ocasiões isso não será verdadeiro ${ }^{45}$

As análises cefalométricas entre os anos de 1940 e 1970 não admitiam grandes alterações craniofaciais por meio do tratamento ortodôntico. A maior parte delas se direcionou ao estudo do crescimento e das alterações dentoalveolares das más oclusões. O desenvolvimento da ortodontia nas décadas de 70 e 80, as novas técnicas de cirurgia ortognática e os modernos conceitos sobre os procedimentos ortopédicos fizeram com que as radiografias cefalométricas sofressem uma nova leitura e fossem estudadas de maneira diferente.

Com essa justificativa, MCNAMARA $\mathrm{Jr}^{90}{ }^{90}$, em 1984, elaborou sua análise, direcionando-a melhor aos modernos métodos de cirurgia ortognática e terapia funcional. Sua análise possibilitou tanto alterações dentárias como no osso basal subjacente. Segundo suas palavras elaborou “uma análise precisa, moderna $e$ principalmente de fácil entendimento, tanto pelo clínico geral como pelos pais do paciente”. Esta metodologia desenvolvida na Universidade de Michigan, EUA, deriva em grande parte das análises de Ricketts e Harvold e, além disso, introduz alguns aspectos originais. Este método relaciona as bases ósseas a uma linha que, partindo do násio, é perpendicular ao plano de Frankfort. Os dados publicados por McNamara são baseados sobre o plano de Frankfort e não sobre a linha horizontal verdadeira. A principal razão para não se proceder assim na construção da análise é que as cefalometrias das quais se originam os dados normativos não foram tomadas em "posição natural da cabeça”. Baseou-se em telerradiografias de três amostras 
diferentes, com boa harmonia entre dentes, ossos e perfil mole. Os grupos estudados foram: crianças compreendidas das amostras dos padrões de Bolton; crianças do Centro Ortodôntico de Burlington e um grupo formado por 111 adultos jovens tratados na Universidade de Michigan. A comparação dos valores obtidos no paciente em questão com as normas fornecidas nesses estudos permitem detectar onde se encontra a discrepância esquelética. Segundo o autor, este método fornece um diagnóstico mais preciso quanto ao procedimento cirúrgico a ser realizado ou à utilização de aparelhos funcionais. A análise permite investigação a fundo no estudo das relações das bases ósseas e das estruturas cranianas. Em resumo, relaciona dentes com dentes, dentes com as bases ósseas, as bases ósseas entre si e ambas com a base craniana. Sugeriu também a utilização do ângulo nasolabial proposto por Sheideman em $1980^{116}$ como guia principal na definição da posição sagital da maxila.

A avaliação do ângulo nasolabial foi discutida em 1992 por FITZGERALD; NANDA; CURRIER ${ }^{47}$ com o objetivo de desenvolver um método confiável e reproduzível para a mensuração desse ângulo e da relação entre o nariz e o lábio superior. Para tanto, os autores propuseram a avaliação dos componentes do ângulo nasolabial em referência ao plano horizontal de Frankfort em 104 indivíduos de oclusão normal e boa estética facial. A comparação da reprodutibilidade pelos ortodontistas revelou que o método proposto para a construção do ângulo nasolabial mostrou-se consistente e de facial reprodução. Enfatizaram que mesmo sendo um recurso para o diagnóstico ortodôntico, o ângulo nasolabial não deve ser utilizado radicalmente, pois não descreve com precisão as alterações do perfil tegumentar. Há casos em que esse ângulo encontra-se dentro de valores normais, mesmo o paciente possuindo protrusão labial e dentária.

OBWEGESER; MARENTETTE ${ }^{100}$ destacaram em 1986 a existência da linha do perfil e o tipo de perfil. A linha do perfil considera estruturas como o nariz e o mento, ao passo que o tipo de perfil é determinado pelas posições espaciais da base anterior do crânio, da maxila e da mandíbula, sugerindo uma classificação concordante com o posicionamento e o tamanho de cada uma destas estruturas. Um perfil esquelético foi construído de acordo com valores cefalométricos médios e sobre este perfil determinou-se um perfil tegumentar. Alterações esqueléticas foram introduzidas em uma ou mais estruturas, tanto no sentido horizontal como no sentido 
vertical, e as alterações tegumentares foram avaliadas, com o intuito de entender como os terços faciais influem no tipo de perfil. O plano de referência horizontal adotado foi o plano de Frankfort, além de utilizarem-se a linha SN, o plano palatino, o plano oclusal e o plano mandibular. Os resultados mostraram a importância de se determinar exatamente o foco da deformidade no planejamento de cirurgias que envolvam a alteração de características faciais, como nos casos de trauma, reconstrução e cirurgias ortognáticas ou cosméticas.

Estudando o relacionamento do perfil facial esquelético com a forma do nariz, ROBISON; RINCHUSE; ZULLO ${ }^{114}$, em 1986, utilizaram uma amostra de 123 jovens do sexo feminino, com idades entre 11 e 20 anos, sem história prévia de patologia, trauma, intervenção cirúrgica ou tratamento ortodôntico. A classificação do perfil esquelético facial baseou-se na relação entre a maxila e a mandíbula, dividindo-se em perfil reto, côncavo ou convexo. Pôde-se observar que mais que 86\% da amostra evidenciou uma alta correlação entre a forma nasal e o perfil esquelético, ou seja, as jovens com perfil reto exibiram um contorno nasal reto, um perfil convexo denotou um nariz convexo e um perfil côncavo foi observado com uma forma nasal igualmente côncava. Os autores enfatizaram a importância do equilíbrio facial total, especialmente da forma nasal, durante o diagnóstico e o planejamento ortodôntico e, ainda, que os ortodontistas deveriam considerar algumas combinações em seus diagnósticos e planos de tratamento, pois a mudança de um aspecto do complexo facial pode alterar toda a harmonia.

Fundamental para cirurgia ortognática é a necessidade de determinar a extensão da displasia e verificar se a maxila ou mandíbula, ou ambas, estão envolvidas. Abundantes formas de análises são atualmente utilizadas no plano de tratamento das deformidades dentofaciais e cada uma examina diferentes medições como sendo a chave para o diagnóstico. Desse modo, quando diferentes análises cefalométricas são utilizadas para examinar o mesmo paciente, diferentes diagnósticos, planos de tratamento e resultados podem ser gerados. Essa disparidade faz o plano de tratamento baseado totalmente na análise cefalométrica malaconselhado.

WYLIE; FISH; EPKER ${ }^{144}$, em 1987, avaliaram a efetividade de cinco análises cefalométricas (Mcnamara; Epker \& Fish; Burstone; Di Paolo e Bütow) No 
diagnóstico das deformidades dentofaciais. Radiografias cefalométricas de dez pacientes foram especificamente selecionadas para ilustrar as diferentes anomalias dentofaciais, em que cada qual foi corrigido por meio de um diferente tipo de procedimento cirúrgico. Os resultados dos “diagnósticos” das análises foram então comparados entre si e entre eles e a forma de tratamento efetuada. Ao se comparar uma análise à outra considerando a especificidade do diagnóstico para cada paciente, as análises mostraram-se inconsistentes. Quando os diagnósticos das várias análises foram então relacionados com o das cirurgias efetuadas, nenhuma análise foi coincidente com o tratamento cirúrgico realizado em mais que $60 \%$ dos casos. Concluíram que a cefalometria não pode ser considerada como um meio primário de diagnóstico na correção das deformidades dentofaciais. Deve-se incluir ao plano de tratamento a avaliação de fotografias faciais, modelos de estudo e, principalmente, o desejo do paciente.

Em 1987, $\mathrm{LEHMAN}^{79}$, ao se referir às análises das deformidades dentofaciais empregadas no passado, relata que a cefalometria tradicional tende a utilizar planos arbitrários, ângulos e distâncias que somente levam em consideração o relacionamento do esqueleto facial a suas várias partes do crânio. As áreas de tecido mole como os lábios, nariz e pescoço também devem ser avaliadas na determinação da cirurgia esquelética se o melhor resultado no perfil quer ser alcançado.

Muitos padrões cefalométricos ${ }^{40,87,123,134}$ sugerem que boa forma facial será obtida se as suas análises forem utilizadas como objetivo de tratamento. Esses padrões basicamente ignoram a análise de tecido mole no plano de tratamento e falham em levar em consideração que o público geral admira um padrão dentofacial mais cheio, protruído, do que os seus padrões cefalométricos permitem ${ }^{102}$.

“Um padrão esquelético desejável, entretanto, não implica em estética facial desejável, nem um padrão esquelético indesejável implica em estética facial indesejável. O último fator compensatório no relacionamento do contorno facial é o tecido mole”, diz o autor ${ }^{102}$.

McNAMARA JR, ELLIS ${ }^{91}$ estudaram em 1988, diversas medidas cefalométricas propostas anteriormente por diversos autores, utilizando uma amostra de indivíduos adultos portadores de oclusão normal e boa estética facial. Observaram-se diferenças estatisticamente significantes entre os sexos em algumas 
medidas lineares e praticamente nenhuma diferença entre as medidas angulares e as proporções, que de maneira geral, são um pouco maiores no sexo masculino, sem apresentar diferença estatisticamente significante. Concluíram dizendo: “ $A$ determinação de valores médios para uma população é de grande utilidade quando os valores orientam o plano de tratamento, não quando estes valores são utilizados como meta do tratamento".

ELLIS; McNAMARA JR. ${ }^{42}$ investigaram, em 1988, a relação entre medidas de posicionamento das bases ósseas que utilizam a linha sela-násion e o plano de Frankfort como referência. Verificaram que as medidas baseadas no plano horizontal de Frankfort são mais precisas na determinação do posicionamento antero-posterior das bases ósseas. O trabalho objetiva alertar os ortodontistas que, quando observarem que os dados cefalométricos não traduzem fielmente a análise clínica facial de um indivíduo, façam uma individualização do caso, pesquisando a variação da inclinação da base do crânio.

Em 1989, CAPELOZZA FILHO et al. $^{28}$ testaram a validade da análise de McNAMARA no diagnóstico das desarmonias dentofaciais. É um artigo composto por 3 grupos de pacientes: um com deficiência mandibular, um com excesso mandibular e um com face longa. Foram analisados com e sem a adoção do ângulo nasolabial como parâmetro de diagnóstico. O índice de concordância deste diagnóstico com o tratamento adotado foi muito maior com o uso do ângulo nasolabial como parâmetro para determinar a posição da maxila. No entanto, apresentou uma forte tendência em aumentar os valores da discrepância mais do que aqueles que seriam inferidos pelo cirurgião, exceto para o avanço mandibular nos casos de Classe II com retrusão mandibular. A adoção do ângulo nasolabial como parâmetro torna-se compreensível, uma vez que atualmente os cirurgiões ortognáticos adotam a cefalometria como coadjuvante no diagnóstico, dando papel principal à análise facial. Verificaram também que os casos de discrepâncias dentoesqueléticas necessitam de avaliação facial, além da análise cefalométrica convencional. A avaliação baseada nos ângulos SNA, SNB e ANB não é confiável quando há alteração na altura do 1/3 inferior da face, e apesar da avaliação de Wits apresentar boa capacidade de leitura, deve ser complementada por análises adicionais, exatamente por não localizar a origem exata das deformidades. 
Em 1990, JACOBSON" ${ }^{71}$, em seu artigo intitulado "Planejamento para cirurgia ortognática - arte ou ciência?”, teceu comentários sobre as análises cefalométricas que teriam como objetivo quantificar o desvio estético dos indivíduos, porém salientou que a cefalometria não deveria ser usada como ferramenta decisiva na correção das deformidades faciais, uma vez que valores lineares e angulares freqüentemente não condizem com descobertas clínicas. Um filme bidimensional cefalométrico de cabeça não retrata a impressão tridimensional obtida pela observação direta. Concluiu seu raciocínio afirmando que, mesmo diante de sofisticadas tecnologias cefalométricas computadorizadas, as decisões finais de uma cirurgia ortognática são desenhadas com impressões clínicas faciais, e por isso a modalidade deve ser estimada mais como arte do que propriamente como ciência.

Em 1990, BITTNER; PANCHERZ ${ }^{19}$ procuraram determinar se as anormalidades sagitais e verticais no relacionamento intermaxilar, interincisivos superiores e inferiores se refletem na morfologia facial. Cento e setenta e duas crianças entre 12 e 14 anos de idade foram selecionadas do departamento de ortodontia, da Universidade de Giessen. Fotografias faciais de frente e de perfil e de radiografias laterais do crânio foram realizadas e, em seguida, efetuaram uma avaliação pessoal da relação interincisivos e intermaxilar por meio do exame visual de fotografias faciais, e também comparações entre as medidas angulares e lineares sobre fotografias e radiografias. Os resultados revelaram que apenas os grandes trespasses horizontais foram reconhecidos de modo confiável nas fotografias faciais, e condições de sobremordida não puderam ser verificadas. As más oclusões de Classe II divisão 2 refletem-se mais freqüentemente na face do que as más oclusões de Classe III. Os autores comentaram ainda que parece não ser apropriado corrigir a má oclusão lutando contra parâmetros cefalométricos esqueléticos. Do ponto de vista estético, por exemplo, nas más oclusões Classe II, $1^{\text {a }}$ divisão, com maxilas prognatas, o tratamento às custas do avanço mandibular parece ser apropriado, uma vez que de fato o prognatismo maxilar geralmente não se reflete na aparência facial.

No prefácio do seu livro texto, BELL ${ }^{17}$ não se furtou a expressar de maneira clara sua opinião ao comparar a cirurgia atual e realizada anteriormente: "Uma revisão de nossos pacientes previamente tratados e publicações passadas revela que muitos de nossos procedimentos cirúrgicos ortognáticos alcançaram proporções 
faciais estéticas, melhora das funções maxilares, e estabilidade oclusal. Em alguns casos selecionados, entretanto, o resultado foi comprometido porque os componentes independentes do tecido mole não foram sistematicamente analisados e tratados”.

VIAZIS $^{135}$, em 1993, verificou a íntima relação existente entre o estabelecimento do perfil facial tegumentar estético e a obtenção de uma oclusão normal. Salientou a importância que a beleza e a atratividade facial desempenham na sociedade. Preconizou também a utilização do plano horizontal verdadeiro como o parâmetro mais indicado para a realização das tomadas radiográficas e fotográficas nas pesquisas sobre as alterações craniofaciais e tegumentares. $\mathrm{O}$ autor afirmou que uma avaliação completa do tecido facial tegumentar permite ao profissional um melhor discernimento a respeito dos problemas dentoesqueléticos que cada paciente possa apresentar.

Segundo CZARNECK ${ }^{34}$, os conceitos tradicionais no diagnóstico ortodôntico não foram corretos ao focalizar excessivamente o uso de estruturas dentárias e esqueléticas do complexo craniofacial. As más oclusões corrigidas com estabilidade aceitável em longo prazo podem não necessariamente atingir o equilíbrio e a harmonia totais da face. Defende que o objetivo primário do tratamento deve ser a harmonia das estruturas faciais.

ARNETT \& BERGMAN ${ }^{6,7}$, em 1993, apresentaram um artigo dividido em duas partes, com o título: "Chaves faciais para o diagnóstico ortodôntico e plano de tratamento”, provavelmente o artigo de revisão mais completo sobre análise facial. Os autores apresentam 19 chaves faciais para funcionarem como ferramentas auxiliares, com o objetivo de aprimorar os resultados facial e dentário. A primeira parte se direcionou para a forma de registro das informações do paciente, fundamental para se saber a extensão correta da deformidade. Os autores enfatizaram o exame do paciente em posição natural da cabeça, com a oclusão em relação cêntrica e os lábios passivos. Os critérios estabelecidos pelos autores podem se aplicar para o exame facial clínico, para a tomada fotográfica e da telerradiografia em norma lateral. A segunda parte do artigo discutiu as diferentes relações entre os componentes faciais, em vista frontal e de perfil, correlacionando-os com o diagnóstico e plano de tratamento. Fizeram referência às desarmonias dentoesqueléticas comumente verificadas na clínica e como estas podem refletir no 
equilíbrio da face. Para os autores, a utilização de guias cefalométricos e de modelos isolados pode resultar em insatisfação do paciente, por entenderem que esses parâmetros não são sinônimos de privilégio estético. A correta compreensão dos traços faciais pode melhorar o diagnóstico, o plano de tratamento e a qualidade dos resultados, tanto dos pacientes cirúrgicos quanto dos não-cirúrgicos.

Pela lógica, a maturação do tratamento ortodôntico-cirúrgico se direcionou para áreas relacionadas à estética facial. O desenvolvimento da especialidade não se limitou ao refinamento dos métodos de fixação e melhora da estabilidade em longo prazo, mas também recebeu aprimoramento na previsibilidade de seus procedimentos $^{74}$. Tornou-se possível um maior esclarecimento na comunicação com o paciente sobre os efeitos da cirurgia ortognática sobre o tecido mole. Programas de computador, com técnicas de manipulação de imagem específicas para os diferentes movimentos cirúrgicos, apresentaram-se como ferramentas fiéis no plano de tratamento. Essa nova tecnologia, indispensável nos dias atuais, permitiu ao clínico verificar o grau de satisfação dos pacientes com o resultado final antes mesmo de se submeterem ao tratamento. O termo “indispensável”, embora de valor ousado, oferece emprego oportuno, visto que $71 \%$ dos pacientes que procuram tratamento ortodôntico-cirúrgico citam a estética como fator motivador ${ }^{113}$.

Em direção oposta ao modelo contemporâneo de tratamento seguiu o estudo de FLYNN; AMBROGIO; ZEICHNER ${ }^{49}$ em 1989. Devido às variações entre os diferentes grupos étnicos, os autores estabeleceram os valores cefalométricos normais para negros norte-americanos adultos. O objetivo desse estudo foi desenvolver valores normativos adaptados a essa etnia segundo a "Análise Cefalométrica para Cirurgia Ortognática”27,78. Os critérios de seleção da amostra consistiram na presença de oclusão normal e ausência de assimetria facial. Os resultados obtidos forneceriam informações proveitosas para o diagnóstico e plano de tratamento cirúrgico. Os autores destacam que a questão da estética facial ideal não foi a intenção da pesquisa. Desse modo, ao contrário de Burstone ${ }^{25}$ que estabeleceu valores cefalométricos a partir do princípio da estética facial, o principal critério de seleção do estudo foi a relação dentária.

A hipótese de que a média é atraente foi testada e confirmada por LANGLOIS \& ROGGMAN ${ }^{76}$, em 1990, com uma técnica que sobrepunha 
fotografias de faces umas sobre as outras para produzir uma composição. Concluíram que as pessoas têm inclinação a preferir o visual neutro, as faces típicas, as que apresentam medidas “que representam a média aritmética das faces” dentro da população estudada. Os biólogos identificaram dois tipos de beleza: a média da população e a composta de pelo menos algumas características dos extremos dessa população.

Para testar essa hipótese, PERRETT; MAY \& YOSHIKAWA ${ }^{103}$, em 1994, utilizaram composições de faces da raça branca e da amarela. Os pesquisadores britânicos e japoneses encontraram coincidências transculturais no julgamento da atratividade da face feminina. Comprovaram que a média não é o único determinante da atratividade, rejeitando o conceito de que a "atratividade é uma média”. Seus estudos mostram que as faces muito atrativas são sistematicamente distintas da média. A similaridade das características faciais atraentes entre as duas culturas foi coerente com as afirmações de que essas características são significantes.

Em 1992, ROTH expressa a sua opinião durante entrevista: “...os objetivos na estética facial para um paciente japonês são suavemente diferentes se ele morar no Japão ou nos Estados Unidos. Também, o objetivo para um paciente japonês diferirá de um paciente leucoderma ou melanoderma. Entretanto, nos Estados Unidos, os padrões para a estética facial são associados ao perfil leucoderma 'norte-americano ideal', ou como é referido, 'perfil hollywoodiano’”.

Reconhecendo a confusão que parece haver quanto aos padrões e normas para a face humana, realizou-se um estudo no departamento de ortodontia da Universidade de Oklahoma, no qual o esforço foi direcionado para desenvolver um perfil facial para a raça branca. CZARNECKI; NANDA; CURRIER ${ }^{34}$, em 1993, desenvolveram uma série de perfis faciais baseados em um perfil ideal, que foi avaliada por 575 profissionais da odontologia. Variando o tamanho dos lábios, do nariz e do mento, o ângulo de convexidade facial e o ângulo facial, esperavam avaliar as combinações mais aceitáveis, assim como as menos desejáveis. Com base nos dados disponíveis na literatura sobre a espessura média do tecido tegumentar e sua relação com o esqueleto subjacente, construiu-se um perfil facial esquelético e de tecidos moles ideal. Este estudo mostrou que o julgamento da protrusão e da retrusão labial dependeu das posições do mento e do nariz. A protrusão labial maior foi 
aceitável quando o nariz e/ou o mento eram maiores. No entanto, foi permitida três vezes mais protrusão labial com o mento grande do que com o nariz grande. Esse achado é altamente significante porque tem maior impacto sobre a consideração dos planos de tratamento. Com nariz e mento relativamente maiores, a dentição mais protruída e os lábios mais cheios são mais aceitáveis para harmonizar a face. Nos “casos limítrofes”, o clínico deve favorecer o tratamento ortodôntico sem extrações. Em qualquer tipo de filosofia de tratamento, a harmonia das características faciais e estéticas é primordial. Ainda que subjetivamente, o clínico deve ser capaz de diferenciar o “normal” (aceitável) do “anormal” (inaceitável).

Embora exista uma tendência crescente para o tratamento de pacientes leucodermas sem extração de pré-molares ${ }^{106}$, segue em outra direção a preferência dos ortodontistas no tratamento de pacientes de origem negra. Em 1999, SCOTT; JOHNSTON Jr. ${ }^{119}$ analisaram o impacto estético no perfil facial da terapia com e sem extração em pacientes afro-americanos. A discriminação para a decisão de extrações se baseou em três variáveis: discrepância dentária, sobressaliência e protrusão do perfil. Analisando dois grupos de observadores, formados por clínicos leucodermas e melanodermas respectivamente, concluíram que o perfil facial melhorou com a terapia extracionista. "Como a protrusão do perfil é uma queixa comum para grande parte desses pacientes e como as extrações dentárias podem oferecer ao menos uma redução modesta da protrusão, pode-se esperar que essa opção de tratamento torne-se potencialmente benéfica”, dizem os autores.

As pesquisas tornam-se necessárias para definir as características faciais objetivadas com o tratamento. Dentro de uma gama enorme de variáveis, como preferências do profissional, influências culturais, nível educacional e subjetividade, deve-se incluir as mudanças que esses conceitos apresentam com o tempo. A história da arte mostra claramente a variabilidade do conceito de beleza através da época analisada e, especificamente, em relação à face. Os trabalhos de NGUYEN, TURLEY ${ }^{97}$, publicado em 1998, e de AUGER; TURLEY ${ }^{12}$, em 1999, mostram a mudança de perspectiva pela qual a beleza facial foi apresentada em revistas de moda e beleza dos EUA durante o século XX. Os resultados mostraram mudanças significantes na região dos lábios. Verificaram-se características associadas com a juventude: maior protrusão labial, mais definição no seu contorno e exposição do 
vermelhão. Esses resultados suportam o conceito de que, na última metade desse século, o público americano passou a valorizar um perfil mais “cheio"102. Além disso, por influência da mídia, essa preferência poderia ser extrapolada para os países ocidentais.

MAGALHÃES; STELLA; EPKER ${ }^{84}$, em 1995, procurando determinar estatisticamente a importância dos critérios antropométricos e cefalométricos no diagnóstico das deformidades em pacientes Classe III, afirmaram: “Nós temos sido culpados por estarmos prejulgando a face de uma pessoa somente pela análise cefalométrica sagital. Talvez, pela confiança nos parâmetros cefalométricos lineares e angulares que estão baseados na simplicidade da interpretação de resultados, ao invés dos rigores mais subjetivos, experimentais da análise dos tecidos moles da face”.

Na discussão sobre o perfil facial e as estruturas dentoesqueléticas, NANDA, $\mathrm{GHOSH}^{95}$ consideraram incompletos os conceitos tradicionais no diagnóstico das deformidades dentofaciais. As análises cefalométricas realizadas por MARGOLIS, DOWNS e STEINER, entre outros, proporcionaram relações dentárias e esqueléticas, oferecendo, porém, apenas uma referência superficial ao equilíbrio dos tecidos moles faciais. Como resultado, os especialistas da área enfatizaram mais o equilíbrio dentoesquelético do que as características gerais da face. Pode-se considerar que a maioria dos ortodontistas segue a suposição dogmática de que, se as estruturas dentárias e esqueléticas estiverem em equilíbrio, as linhas faciais automaticamente farão o mesmo. Os avanços recentes aumentaram a capacidade de o ortodontista, em cooperação com o cirurgião bucomaxilofacial, equilibrar as relações entre nariz, lábios e mento. Os autores ${ }^{95}$ acreditam que a qualidade da estética facial é beneficiada pelas relações dentárias e esqueléticas harmoniosas, mas não depende totalmente delas. A maioria dos clínicos pode descrever a face ideal e bela, mas existem tantas variações dessa norma hipotética quanto indivíduos no mundo. Os conceitos ideais de beleza diferem não só com base em raça e sexo, mas também de um indivíduo para outro. A aparência das pessoas é resultado das formas somadas às influências dos traços de personalidade. A avaliação da estética facial é subjetiva para os leigos, e inclui fatores como o equilíbrio e a harmonia das partes constituintes, simetria e proporções, cor e estilo do cabelo. Até onde é possível, deve-se eliminar os 
fatores extrínsecos, e o processo de tomada de decisão deve ser estruturado sobre princípios objetivos.

Para ANDREWS ${ }^{3}$, em 1997, os iniciantes em ortodontia serão capazes de estabelecer um diagnóstico utilizando tanto a cefalometria tradicional como o método cefalométrico dos seis elementos da harmonia orofacial, mas por razões diferentes.

A abordagem dos seis elementos é melhor para o diagnóstico do que utilização das médias desenvolvidas a partir de normas computadorizadas, porque utiliza novos pontos de referência, que resultarão em tratamentos antero-posteriores individualizados para cada paciente. Para o autor, a superioridade da abordagem dos seis elementos é óbvia. A cefalometria tradicional só não será obsoleta para a avaliação dos resultados do tratamento por meio das sobreposições, pois nesse caso os referentes são únicos para cada indivíduo. Afirmou, ainda, não existir correlação entre os referentes da cefalometria convencional e o que é esteticamente único para cada paciente.

FERRARIO et al. ${ }^{46}$, em 1998, desenvolveram uma investigação no intuito de elaborar uma medida antero-posterior das discrepâncias maxilomandibulares que considerasse tanto tecidos duros como moles, e verificar a correlação desta medida com uma medida linear confiável e bem estabelecida da discrepância anteroposterior. Os autores avaliaram as telerradiografias pré-tratamento de 300 pacientes, utilizando a análise de WITS, e a análise de WITS modificada para os tecidos moles. Os resultados mostraram uma correlação significante entre as medidas realizadas nos tecidos esqueléticos e tegumentares em todas as faixas etárias estudadas na amostra. Estes resultados são mostrados pelo autor como uma prova da direção irreversível tomada pelos meios de diagnóstico em direção a uma objetividade atrelada à tecnologia.

IAGUE NETO ${ }^{69}$, em 1998, avaliou a relação entre o perfil facial tegumentar e as estruturas dentoesqueléticas maxilomandibulares. Utilizou uma amostra de 49 telerradiografias tomadas de adultos jovens, sendo 27 do sexo feminino (média de 17a 9m) e 22 do sexo masculino (média de 17a 10m), com oclusão normal e boa estética facial. De acordo com os resultados obtidos, observou-se que o perfil facial tegumentar, avaliado por meio de medidas angulares, não demonstrou um 
dimorfismo sexual. Houve uma correlação entre a linha dentoalveolar superior, tomada do ponto A ao ponto vestibular do incisivo superior, e a inclinação do lábio superior. A inclinação do incisivo inferior em relação à linha $\mathrm{N}$ perpendicular ao plano de Frankfort (Nperp) influenciou a inclinação do lábio inferior.

Em entrevista, ARNETT $^{10}$ relata que o diagnóstico da má oclusão através de normas cefalométricas não é confiável. A suposição de que a correção da má oclusão baseada em valores normativos cefalométricos proporcionava uma estética facial adequada não era sempre verdadeira, podendo algumas vezes levar o profissional a resultados abaixo das suas expectativas e das expectativas do indivíduo. Como explicações possíveis para a inadequação da cefalometria, destaca: o tecido mole que recobre dentes e osso pode variar tanto que o padrão dentoesquelético pode ser inadequado na avaliação da desarmonia facial; quando a base craniana é utilizada como linha de referência para medir o perfil facial podem ser gerados dados adulterados; cada estudo cefalométrico examina diferentes medidas como sendo a chave para o diagnóstico. Portanto, quando análises cefalométricas diferentes são utilizadas para examinar o mesmo diagnóstico podem ser gerados diagnósticos, planos de tratamento e resultados diferentes. O autor conclui que a cefalometria possa ser um recurso mais confiável como um meio de predição das alterações teciduais quando não houver uma desarmonia esquelética.

BERGMAN $^{18}$, em 1999, se propôs a discutir 18 medidas exclusivas do tecido mole facial, importantes para o sucesso do tratamento ortodôntico. As análises ortodônticas mais comuns baseavam-se em medidas esqueléticas e dentárias, dando pouca ênfase às medidas do tecido mole. Um exame da face seria fundamental para entender as mudanças na aparência facial resultantes do tratamento ortodôntico, bem como para beneficiar o diagnóstico e o plano de tratamento. Afirmou que o conhecimento dos padrões faciais e das características específicas do tecido mole do indivíduo poderia levar à obtenção de normas individualizadas, que ajudariam a melhorar a atratividade facial.

Em 1999, ARNETT et al. ${ }^{10}$ apresentaram uma análise cefalométrica que enfatiza as medições do tecido mole facial como um guia primário para o tratamento oclusal e para o plano de tratamento das deformidades dentofaciais. Os autores explicaram que a análise é um instrumento radiográfico desenvolvido como 
conseqüência da filosofia defendida em publicações passadas ${ }^{6,7}$. Para tanto, 46 modelos leucodermas, sendo 20 homens e 26 mulheres, compreenderam a amostra. Todos os indivíduos possuíam oclusão normal e razoável equilíbrio facial, avaliados por um dos investigadores. Destaca-se em sua pesquisa a metodologia empregada: alguns detalhes anatômicos do terço médio que normalmente não seriam mostrados na radiografia receberam marcadores metálicos, posicionados no lado direito da face. Essas estruturas se tornaram o alicerce no diagnóstico e plano de tratamento do terço médio facial. Em seguida, uma telerradiografia em norma lateral foi obtida, em posição natural da cabeça, com os côndilos assentados e lábios passivos.

Em comparação com os dados apresentados por ARNETT \& BERGMAN ${ }^{6,7}$ em 1993, a "análise cefalométrica de tecido mole” também se direciona para o exame do tecido tegumentar, mas com algumas vantagens. Os primeiros artigos sugerem a avaliação facial no exame clínico do paciente e, por isso, de precisão limitada. Com a análise feita com base na cefalometria, os pontos de referência no tecido mole podem ser localizados facilmente, marcados e avaliados. Uma facilidade para a sua execução é a disponibilidade em programa de computador para predicção de imagem.

ALCALDE et al. ${ }^{1}$, em 2000, conduziram um estudo para estabelecer as normas cefalométricas para o tecido mole em japoneses. O critério de seleção de um grupo foi a presença de relação dentária normal, sem fazer menção à estética, e o outro grupo, denominado supernormal, foi selecionado por dez examinadores com referência à estética facial. Os autores compararam esses valores com um terceiro grupo formado por indivíduos leucodermas. Os resultados demonstraram que os valores do tecido mole do grupo supernormal diferiram menos dos índices normativos para leucodermas do que da amostra com oclusão normal. Entretanto, recomendaram cautela quando essas normas estéticas forem aplicadas em descendentes de japoneses que vivem no exterior, devendo o clínico discernir se o tratamento deve ser efetuado seguindo normas étnicas ou culturais. Os parâmetros de tecido mole foram estabelecidos para uma amostra japonesa adulta normal e outra esteticamente agradável, e comparados a uma amostra branca. Deve-se ter cuidado quando tentamos aplicar essas normas étnicas para grupos japoneses fora do Japão. Como afirmado por POGREL ${ }^{104}$, é necessário ter uma discussão aberta e desinibida 
com o paciente para discernir se o tratamento deveria ser conduzido por uma norma étnica ou cultural. Não é o propósito desses dados serem utilizados como modelo e deve-se ter em mente que os tratamentos ortodôntico e cirúrgico devem ser planejados de acordo com as necessidades individuais de cada paciente ${ }^{1}$.

Em 2002, REIS; CAPELOZZA FILHO; MANDETTA ${ }^{107}$, em um estudo das características dentárias em indivíduos com perfil facial normal, referiu-se ao termo “normal” como o que se repete na maioria da população. A amostra de seu trabalho intentou representar a maioria da população de adultos. Demonstraram que $7 \%$ da amostra apresentou oclusão normal e 93\%, más oclusões, sendo 48\% Classe I, 42\% Classe II e 3\% Classe III. Em sua pesquisa, destaca-se o critério de seleção da amostra, caracterizada pelo selamento labial passivo. A intenção foi selecionar uma amostra de indivíduos "normais" do ponto de vista da análise facial, e o selamento labial passivo foi considerado como a condição mínima para a normalidade funcional do perfil. Para os autores, apesar de pouco freqüente em artigos científicos, a utilização da terminologia "normal" refere-se ao que se repete na maioria da população e, ainda que ousada, apresenta-se bastante apropriada.

Em 2003, PROFFIT; WHITE Jr.; SARVER ${ }^{106}$ estabeleceram a expressão “paradigma do tecido mole”. O termo paradigma pode ser interpretado como uma nova perspectiva baseada sobre uma estrutura científica emergente, com novos pensamentos e critérios, e universalmente aceita. Para os autores, desde o início da especialidade, a teoria e prática ortodôntica se basearam no paradigma de Angle. O objetivo de tratamento era produzir a oclusão perfeita dos dentes e, desse modo, a beleza facial naturalmente seria alcançada. Na ortodontia contemporânea dá-se ênfase às considerações ao tecido mole, na sua relação com a estética facial, à teoria de equilíbrio muscular, determinante da estabilidade dos resultados, aos efeitos do movimento dentário sobre o suporte periodontal e à adaptação neuromuscular após o tratamento ortodôntico-cirúrgico.

CAPELOZZA FILHO ${ }^{29}$,em 2004 propõe uma nova forma de classificação das deformidades dentofaciais. Além da relação sagital dos molares, sugere uma classificação dentária ou baseada no envolvimento esquelético da má oclusão. O autor apresenta o conceito de padrão facial, que pode ser definido como “a 
manutenção da configuração da face através do tempo”. Nessa linha de pensamento, encontram-se indivíduos do Padrão I, II, III, face longa e face curta.

Em 2007, estudos nos mostram uma nova tecnologia que vem para melhorar ainda mais plano de tratamento ortodôntico e cirúrgico, o planejamento em três dimensões. Essa nova forma de cefalometria e análise facial utilizando tomografias computadorizada cone bean juntamente com fotografias 3D ou scanners de laser já é utilizada e vem obtendo excelentes resultados ${ }^{74,98}$.

O período de desenvolvimento que presenciamos atualmente altera a ordem do roteiro do diagnóstico e planejamento ortodôntico. A estética facial abandonou o papel de coadjuvante e adquiriu papel principal no posicionamento dos dentes sobre o osso basal, sendo atualmente de aceitação geral oferecer maior vigor à análise do perfil e determinadas extensões tegumentares, com respeito ao osso basal ${ }^{70}$.

Um conceito relativamente novo se inicia no plano de tratamento ortodôntico, com maior enfoque na posição dos incisivos superiores ${ }^{11,70,89}$. A experiência clínica parece confirmar que o lábio superior exibe um acompanhamento de aproximadamente $2 / 3$ da movimentação lingual ou vestibular dos incisivos superiores $^{51}$. Esta constatação permite que se possa programar satisfatoriamente a movimentação do incisivo superior a fim de melhor harmonizá-lo com a previsão do perfil labial correspondente. Após a nova localização do incisivo superior, se estabelece o "ponto de oclusão" do incisivo inferior, coincidente com a face lingual daquele dente, e a quantidade de movimentação dos demais dentes da arcada.

Na análise da evolução ortodôntica como especialidade, a posição rígida dos incisivos sobre o osso basal cedeu lugar ao perfil tegumentar como plano de tratamento. Os incisivos inferiores não seguem mais uma discrepância cefalométrica rígida e se permitem ao movimento de vestibularização. Com maiores recursos de tratamento, o ortodontista inverteu o sentido terapêutico e estuda o perfil de cada paciente previamente ao posicionar os dentes.

Nos casos de problemas esqueléticos ou dentoalveolares severos, nos quais somente a realização do tratamento ortodôntico repercutiria negativamente no perfil facial, a cirurgia ortognática manifesta-se como um apoio sólido. A decisão do tratamento está na dependência da análise facial. De um modo geral, quando a 
discrepância esquelética compromete a face, o tratamento ortodôntico isolado está contra-indicado.

Recentemente, ARNETT; McLAUGHLIN ${ }^{11}$ publicaram um livro descrevendo de maneira sistemática e objetiva o plano de tratamento de pacientes que necessitam de tratamento ortodôntico ou associado à cirurgia ortognática. Sob o título "Planejamento facial e dentário para ortodontistas e cirurgiões bucomaxilofaciais", os autores defendem o equilíbrio e harmonia facial como objetivo principal de tratamento. Destaca-se a maneira sistemática e metódica como documentam as informações do paciente, essencial para a análise facial e planejamento do tratamento.

Os casos chamados "limítrofes”, que oferecem dificuldades para a decisão de se realizar a cirurgia ortognática ou em receberem tratamento ortodôntico somente, são descritos em detalhes e compreendem o escopo do livro. De maneira interessante, o planejamento do tratamento ortodôntico se encontra no último capítulo. Ao contrário do que foi apregoado no passado, o movimento dentário deve ser determinado somente após o planejamento da face e da posição dos incisivos. "Nós firmemente acreditamos que essa é a ordem correta”, dizem os autores.

Em épocas recentes, a primeira preocupação do clínico tem sido então, de ordem estética, dirigida principalmente ao perfil tegumentar inferior. Após a identificação do melhor perfil a ser conseguido, o movimento ortodôntico dos dentes é planejado. Essa mudança na estratégia de planejamento demonstra aceitação crescente pela comunidade ortodôntica, resultando, naturalmente, em melhor satisfação por parte dos pacientes.

No entanto, como declaram ARNETT \& McLAUGHLIN"11: “A beleza facial pode ser identificada, mas definir os seus componentes de maneira objetiva é difícil”. A perspectiva do conceito de beleza se anuvia por preferências pessoais, tendências culturais e sofre mudanças com o passar do tempo. Entretanto, a definição do conceito de estética facial torna-se um passo muito importante no esforço de incorporá-la nos objetivos a serem almejados na prática clínica. 
3- Proposição 



\section{Proposição}

O objetivo desse trabalho consistiu em analisar comparativamente as medidas da análise cefalométrica dos tecidos moles de pacientes Norte Americanos com as medidas realizadas em Brasileiros, utilizando-se o software da DOLPHIN ${ }^{\circledR}$, e estabelecer as grandezas numéricas dos pacientes brasileiros, para que essas medidas possam ser utilizadas no planejamento cirúrgico seguindo a análise cefalométrica dos tecidos moles proposta por ARNETT ( ). 

4- Material e Métodos 



\section{Material e Métodos}

O presente estudo constituiu-se de um grupo experimental e de um grupo controle.

\subsection{Amostra}

\subsubsection{Grupo Experimental}

Para a constituição da amostra do grupo experimental seguiram-se os mesmos parâmetros do grupo controle. A qualidade da face foi desvinculada de sua posição e os critérios de inclusão foram baseados no equilíbrio das partes faciais, não sendo consideradas suas qualidades.

De maneira simples e prática pode-se dizer que os critérios de inclusão da amostra são os listados abaixo:

1. Leucodermas;

2. $\quad$ Filhos de pais brasileiros, descendentes de Mediterrâneos;

3. Apresentam faces consideradas harmônicas;

4. Portadores de oclusão normal, sem mutilações nos arcos dentários;

5. Nunca submetidos a tratamento ortodôntico

6. Pacientes entre 18 e 30 anos. 
Cento e nove indivíduos satisfizeram os critérios de inclusão acima descritos e todos foram fotografados com a mesma máquina digital (Nikon Coolpix 990) e de forma padronizada para a aquisição de fotografia em alta resolução (1280x960) de frente e de perfil.

De forma sistematizada estas fotografias foram projetadas em condições controladas e avaliadas por 2 alunos de pós-graduação e um docente da área de cirurgia.

A seleção da amostra foi realizada por score sem que um examinador pudesse influenciar os demais examinadores. Ao final da avaliação dos 109 indivíduos préselecionados 60 foram escolhidos para integrarem o grupo experimental.

A metodologia proposta teve a intenção de realizar a análise cefalométrica dos tecidos moles (ACTM) de todos os pacientes da amostra, seguindo os princípios descritos por ARNETT ${ }^{9}$, em 1999, e considerando os valores de sua análise como sendo o grupo controle do presente estudo.

\subsubsection{Grupo Controle}

Considerando-se o fato de que a análise cefalométrica dos tecidos moles (ACTM) foi proposta e descrita por ARNETT ${ }^{9}$, mais uma vez se torna importante salientar que os números encontrados pelos autores Norte Americanos tornaram-se o grupo controle do presente estudo.

Os dados cefalométricos utilizados na análise descrita por ARNETT $^{9}$ constituíram de 46 pacientes caucasianos adultos, (20 homens e 26 mulheres). Os cefalogramas foram digitalizados e calculados os valores médios, de desvio padrão e de probabilidade. Todos os pacientes apresentavam oclusão de classe I não tratada ortodonticamente e foi realizada uma distinção entre a qualidade das partes da face (cabelos, olhos, pele, etc.) e posição das mesmas. Os critérios de inclusão se basearam no equilíbrio das partes faciais, não sendo consideradas suas qualidades, tais como cor dos olhos, tom da pele ou dos cabelos. 


\subsection{Métodos}

\subsubsection{A Obtenção das Radiografias Cefalométricas}

Antes do início da análise cefalométrica, todos os pacientes do grupo experimental foram avaliados clinicamente em posição natural da cabeça, com os côndilos assentados e os lábios em repouso. O posicionamento correto durante o exame clínico foi imperativo para se assegurar a confiabilidade da ACTM, como proposta por ARNETT ${ }^{9}$. O exame clínico da face de todos os indivíduos foi realizado, conforme proposto por ARNETT \& BERGMAN ${ }^{6,7}$, com ênfase especial para as estruturas do terço médio da face que não aparecem na análise cefalométrica padrão. Em particular, o contorno da rima infraorbitária, da maça do rosto, a região subpupilar e a base alar foram observadas para indicar a posição antero-posterior da maxila.

Previamente às tomadas radiográficas, pequenos marcadores metálicos foram colocados no lado direito da face (Figura 1) para marcar na radiografia as estruturas chaves do terço médio da face (Figura 2). Essas estruturas essenciais da face média, embora perdidas nas radiografias convencionais, foram ressaltadas com a utilização desses marcadores, tornando-se um passo fundamental para o diagnóstico e tratamento das deficiências do terço médio da face. Também foi colocado um marcador na linha mento-pescoço (Figuras 1 e 2).

Após os passos descritos anteriormente, todos os pacientes foram radiografados em posição natural da cabeça, côndilos assentados e lábios bem relaxados.

As radiografias foram realizadas utilizando-se sempre o aparelho de raios- $\mathrm{X}$ do Departamento de Estomatologia da Faculdade de Odontologia de Bauru - FOB-USP. 


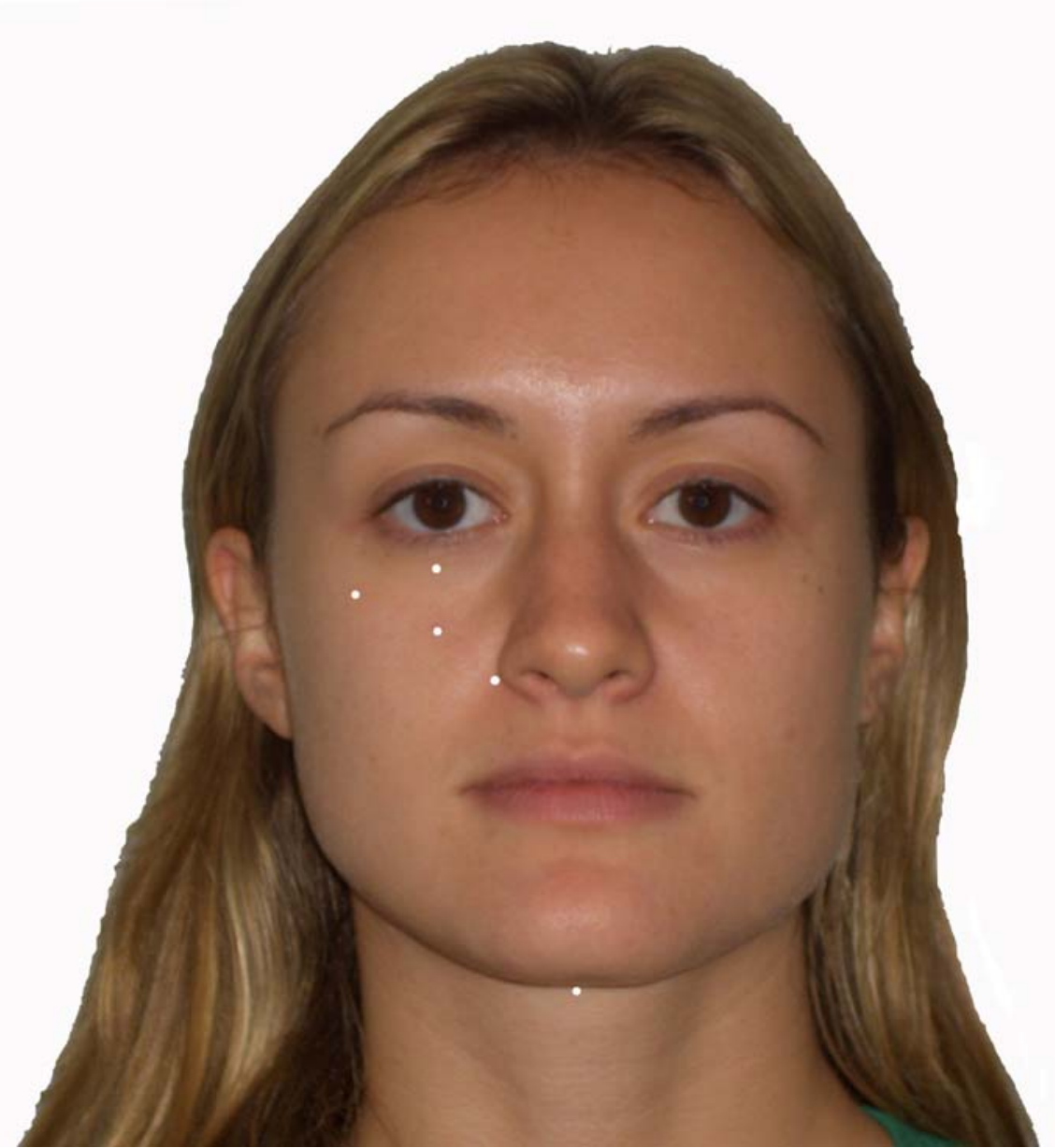

Figura 1 - Marcadores metálicos posicionados para a realização da radiografia tele lateral. De cima para baixo os marcadores estão posicionados nos pontos cefalométricos da rima orbitária, ponto da maça, ponto da região subpupilar, base nasal e ponto da linha mento-pescoço. 


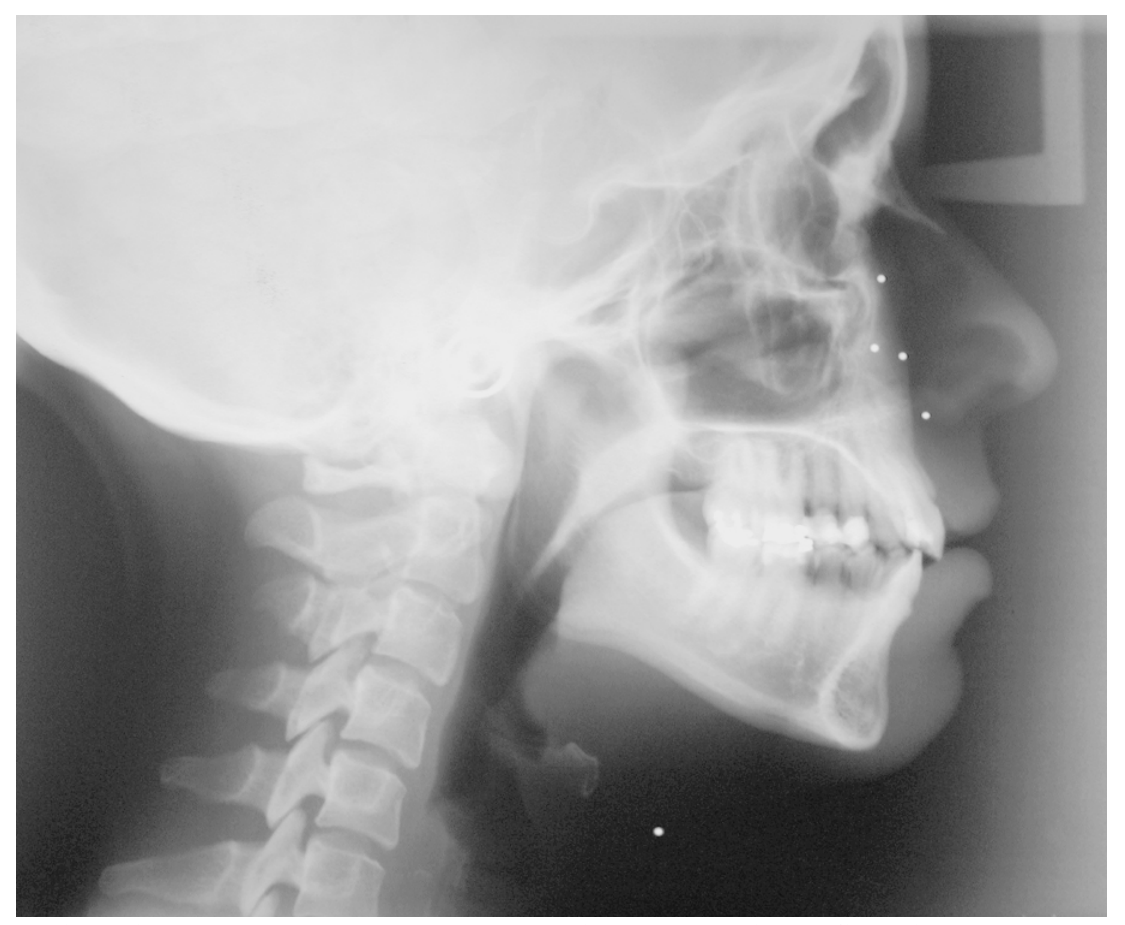

Figura 2 - Visualização dos marcadores metálicos na radiografia tele lateral. De cima para baixo os marcadores estão posicionados nos pontos cefalométricos da rima orbitária, ponto da maça, ponto da região subpupilar, base nasal e ponto da linha mento-pescoço. 


\subsubsection{A Elaboração dos Cefalogramas}

As telerradiografias foram escaneadas com o Scanner Agfa Arcus II (Agfa, Morfsel, Bélgica), utilizando o programa Agfa Fotolook 3.5, no sistema RGB, com resolução de 200\% de ampliação e 225 dpi. Todas as radiografias foram digitalizadas com o auxilio de uma régua própria do Dolphin (Figura 3), utilizada para se corrigir a magnificação da imagem radiográfica causada durante a exposição dos filmes cefalométricos. As imagens foram ajustadas no programa Adobe-Photoshop 7.0 (Adobe System, San Diego, Estados Unidos) e posteriormente indexadas no programa Dolphin Imaging, versão 9.0 (Figura 4), no qual puderam ser ampliadas em até $200 \%$ sem perda de qualidade. A demarcação dos pontos de referência dentoesqueléticos e o traçado anatômico que compõem o cefalograma foram realizados digitalmente em ambiente de penumbra. Quando as estruturas bilaterais não eram coincidentes, efetuo-se o traçado médio entre as imagens (Figura 5).

Figura 3 - Régua própria do Dolphin. 


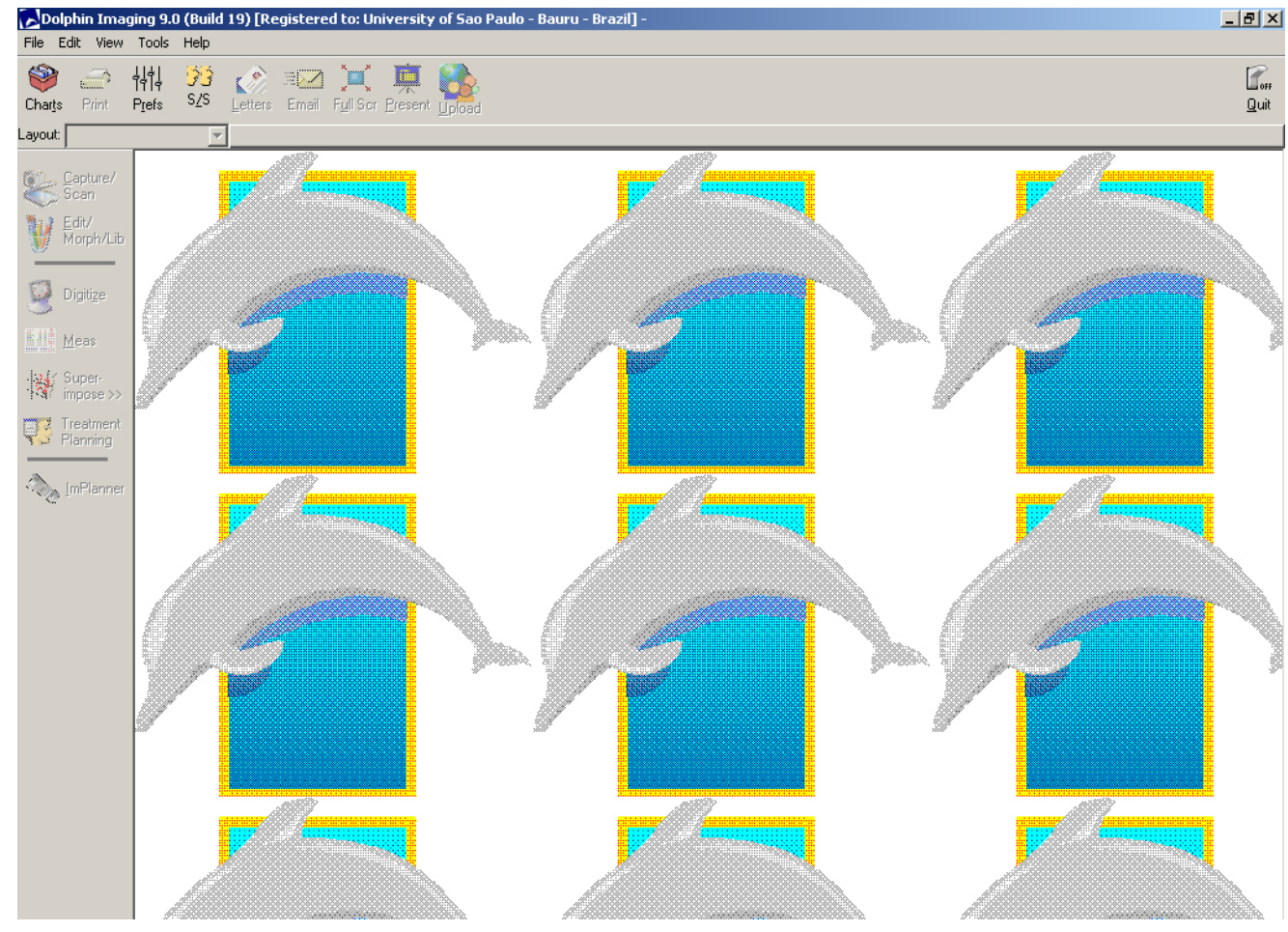

Figura 4 - Interface do software Dolphin Imaging, versão 9.0.

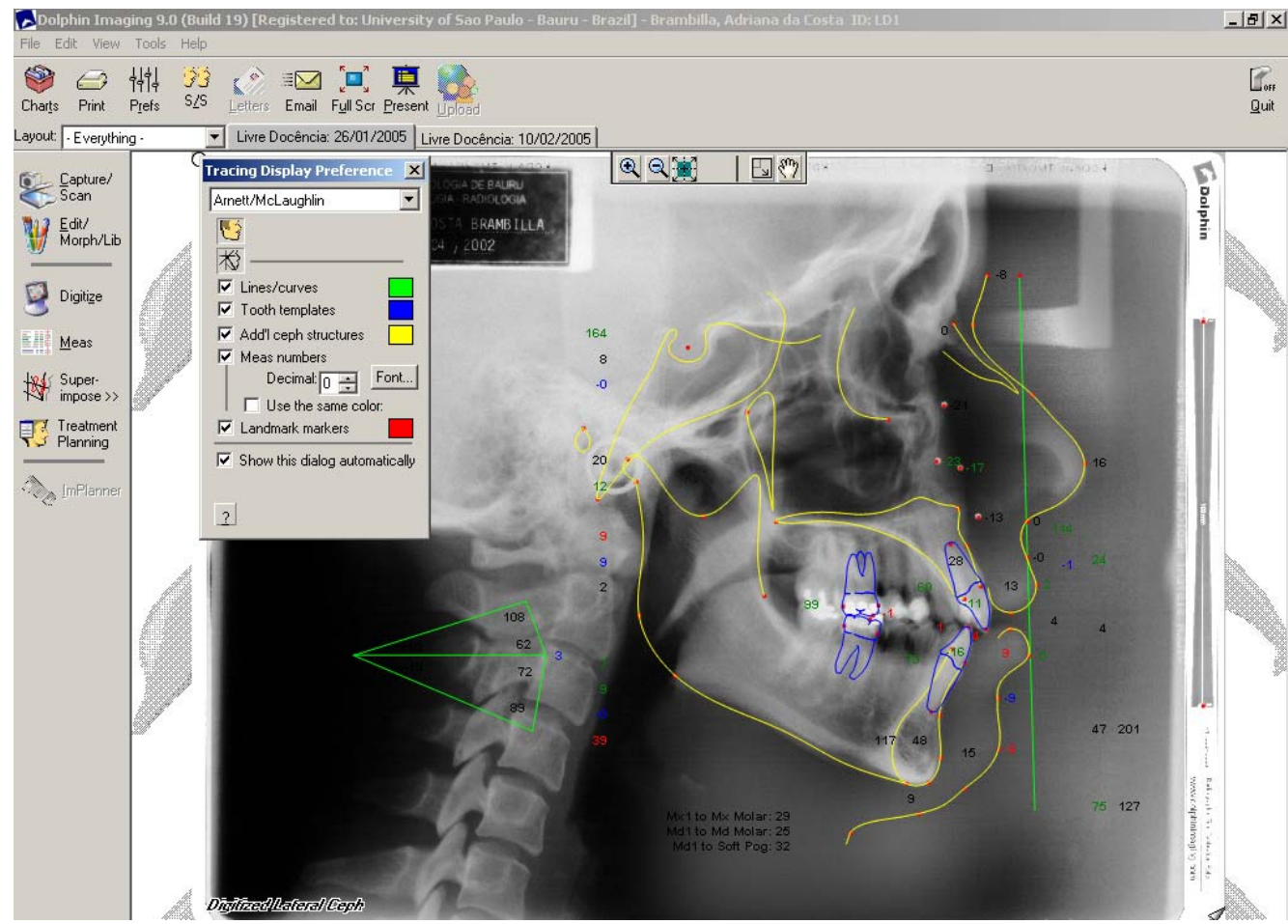

Figura 5 - Interface do software Dolphin Imaging, versão 9.0 mostrando o cefalograma. 


\subsubsection{Delimitação do Desenho Anatômico}

Foram delimitadas as seguintes estruturas (Figura 6):

- $\quad$ ossos nasais e frontal;

- $\quad$ sela túrcica;

- $\quad$ osso esfenóide;

- meato acústico externo;

- $\quad$ cavidades orbitárias;

- $\quad$ fissura pterigomaxilar;

- pório anatômico;

- maxila;

- mandíbula;

- incisivos centrais e primeiros molares permanentes superiores e inferiores;

- $\quad$ perfil facial tegumentar, iniciando-se acima da glabela e prolongandose até o contorno anterior do pescoço.

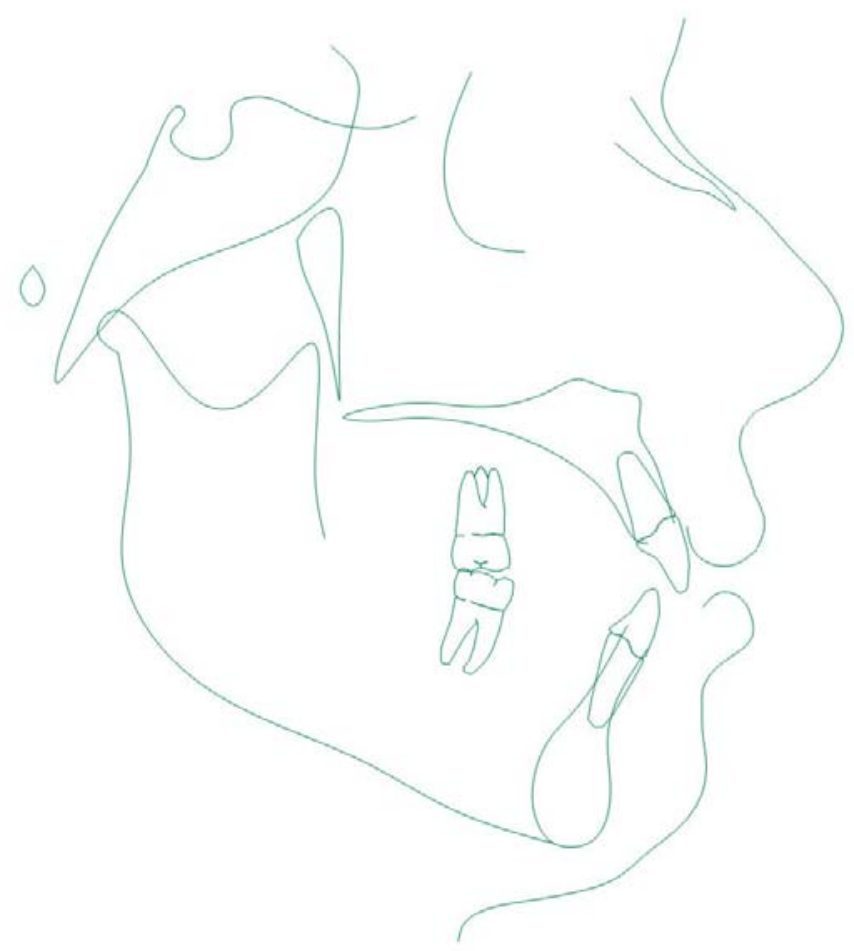

Figura 6 - Delimitação do desenho anatômico. 


\subsubsection{Demarcação dos Pontos Cefalométricos}

Foram demarcados 16 pontos no perfil facial tegumentar e 22 pontos nas estruturas dentoesqueléticas, conforme visualizado na Figura 7.

\section{PONTOS NO TECIDO MOLE}

1. Gl' (glabela tegumentar): o ponto mais anterior localizado no perfil mole, acima da órbita;

2. N’ (násio tegumentar): ponto localizado pouco acima da maior concavidade entre o nariz e a fronte;

3. Prn (pronasal): ponto mais anterior do contorno do nariz;

4. Sn (subnasal): ponto situado na confluência entre a margem inferior da columela nasal e o filtro labial;

5. Ma (malar tegumentar): ponto metálico da curvatura do osso malar;

6. Io (infra orbitário tegumentar): ponto metálico da rima orbitária tegumentar;

7. $\quad$ Bn (base nasal): ponto metálico na base alar;

8. Sp (ponto subpupilar tegumentar): ponto metálico da região subpupilar tegumentar;

9. A' (ponto A tegumentar): o ponto mais posterior localizado na concavidade do lábio superior;

10. Ls (lábio superior): ponto localizado na junção pele-mucosa entre o lábio superior e o filtro;

11. Li (lábio inferior): ponto localizado na junção pele-mucosa entre o lábio inferior e a concavidade do queixo;

12. B' (ponto B tegumentar): ponto mais posterior da concavidade entre o lábio inferior e o mento;

13. Pog' (pogônio tegumentar): ponto mais anterior do contorno do mento tegumentar; 
14. Gn’ (Gnátio tegumentar): ponto médio entre o ponto mais anterior e inferior do tecido mole do mento no plano sagital mediano;

15. Me' (mentoniano tegumentar): ponto inferior do contorno do mento tegumentar.

16. Pe’ (pescoço mandíbula): ponto onde termina o pescoço e inicia a mandíbula tegumentar.

\section{PONTOS NOS TECIDOS DUROS}

17. N (násio): intersecção da sutura internasal com a sutura frontonasal;

18. Or (orbitário): ponto mais inferior da margem infraorbitária;

19. S (sela): localizado no centro da sela túrcica;

20. Po (pório): ponto mais superior do meato acústico externo;

21. Ba (básio): o ponto mais inferior da margem anterior do forame Magno;

22. Pt (pterigomaxilar): ponto mais superior e posterior, no contorno da fissura pterigomaxilar;

23. ENA (espinha nasal anterior): o limite anterior do assoalho nasal;

24. A (ponto A): ponto mais profundo da concavidade anterior da maxila;

25. AIS (ápice do incisivo superior): a extremidade do ápice do incisivo central superior;

26. BIS (borda do incisivo superior): a extremidade da coroa do incisivo central superior;

27. Is (incisivo superior): ponto mais anterior, na superfície vestibular do incisivo central superior;

28. Ii (incisivo inferior): ponto mais anterior, na superfície vestibular da coroa do incisivo central inferior;

29. BII (borda do incisivo inferior): a extremidade da coroa do incisivo central inferior;

30. AII (ápice do incisivo inferior): a extremidade do ápice do incisivo central inferior;

31. 6S (cúspide do molar superior): a extremidade da cúspide mesial do primeiro molar superior; 
32. 6I (cúspide do molar inferior): a extremidade da cúspide mesial do primeiro molar inferior;

33. B (ponto B): ponto mais profundo da concavidade anterior da mandíbula;

34. Pog (pogônio): ponto mais proeminente do contorno anterior do mento ósseo;

35. Gn (gnátio): ponto projetado no osso basal da mandíbula formado pela bissetriz dos pontos Pogônio e Mentoniano;

36. Me (mentoniano): ponto mais inferior do contorno da sínfise mentoniana;

37. Go (gônio): ponto projetado no ângulo da mandíbula formado pela bissetriz das retas dos limites inferior e posterior da mandíbula;

38. Co (côndilo): ponto mais superior e posterior do contorno do côndilo.

Os pontos de referência foram demarcados seguindo as especificações de STEINER $^{123}$, em 1953, KROGMAN \& SASSOUNI ${ }^{73}$, em 1957, SCHEIDEMAN et al. ${ }^{118}$, em 1980, e por McNAMARA Jr. ${ }^{90}$, em 1984. 


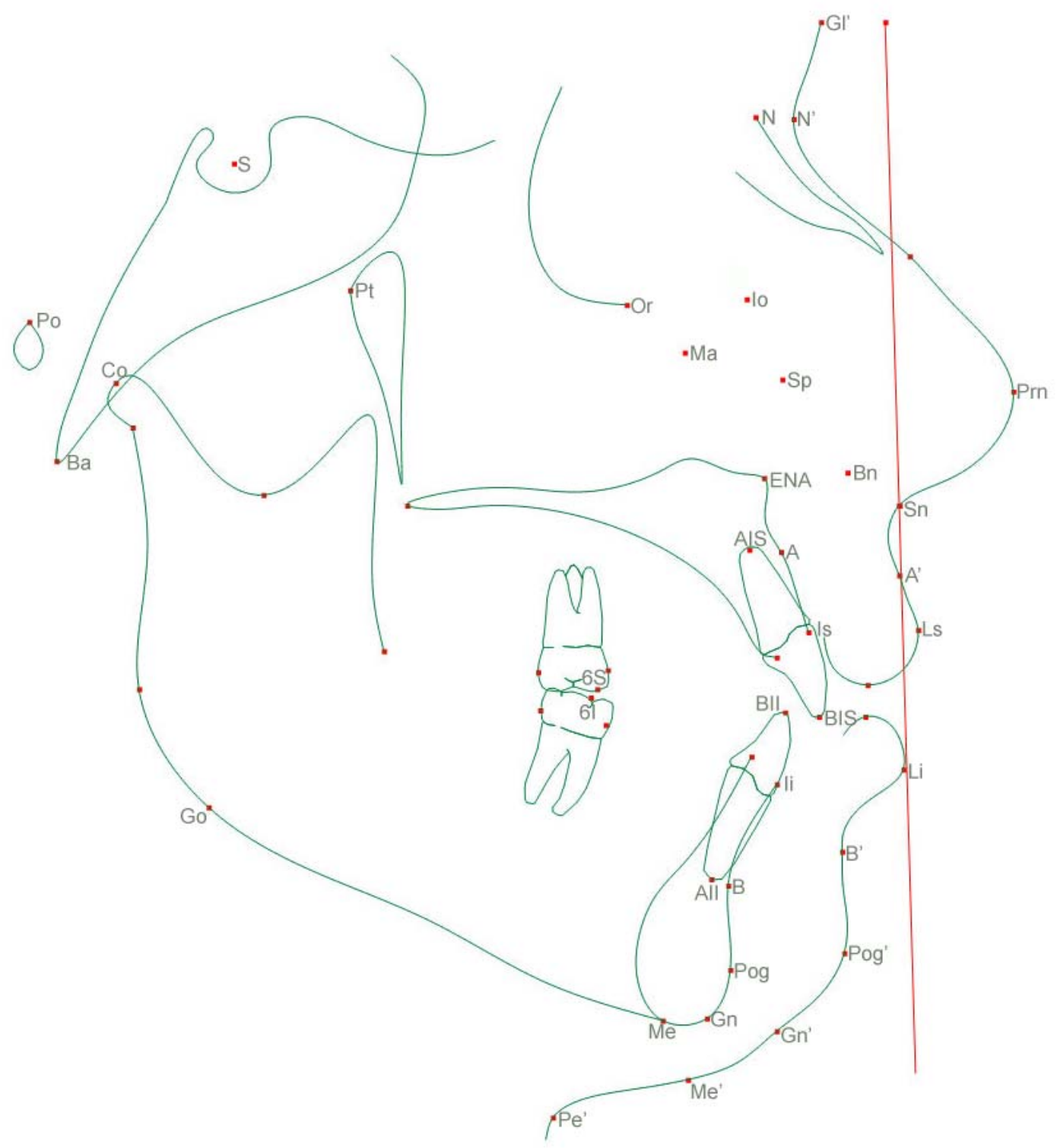

Figura 7 - Pontos de referência do traçado cefalométrico 


\subsubsection{Determinação da Linha Vertical Verdadeira}

Uma corrente metálica unida a um prumo foi posicionada próxima à margem anterior do chassi porta-filme de maneira que sua imagem apareça à frente do contorno do perfil dos tecidos moles quando da obtenção da telerradiografia lateral $^{39,93,100}$. A imagem radiopaca da corrente metálica representa uma linha vertical que forma um ângulo de $90^{\circ}$ com o solo. A partir desta referência vertical pôde-se traçar uma perpendicular, obtendo-se a linha denominada Horizontal Verdadeira. Posteriormente, desenha-se uma linha perpendicular à Horizontal Verdadeira, através do ponto Subnasal, denominada Linha Vertical Verdadeira (Figura 8).

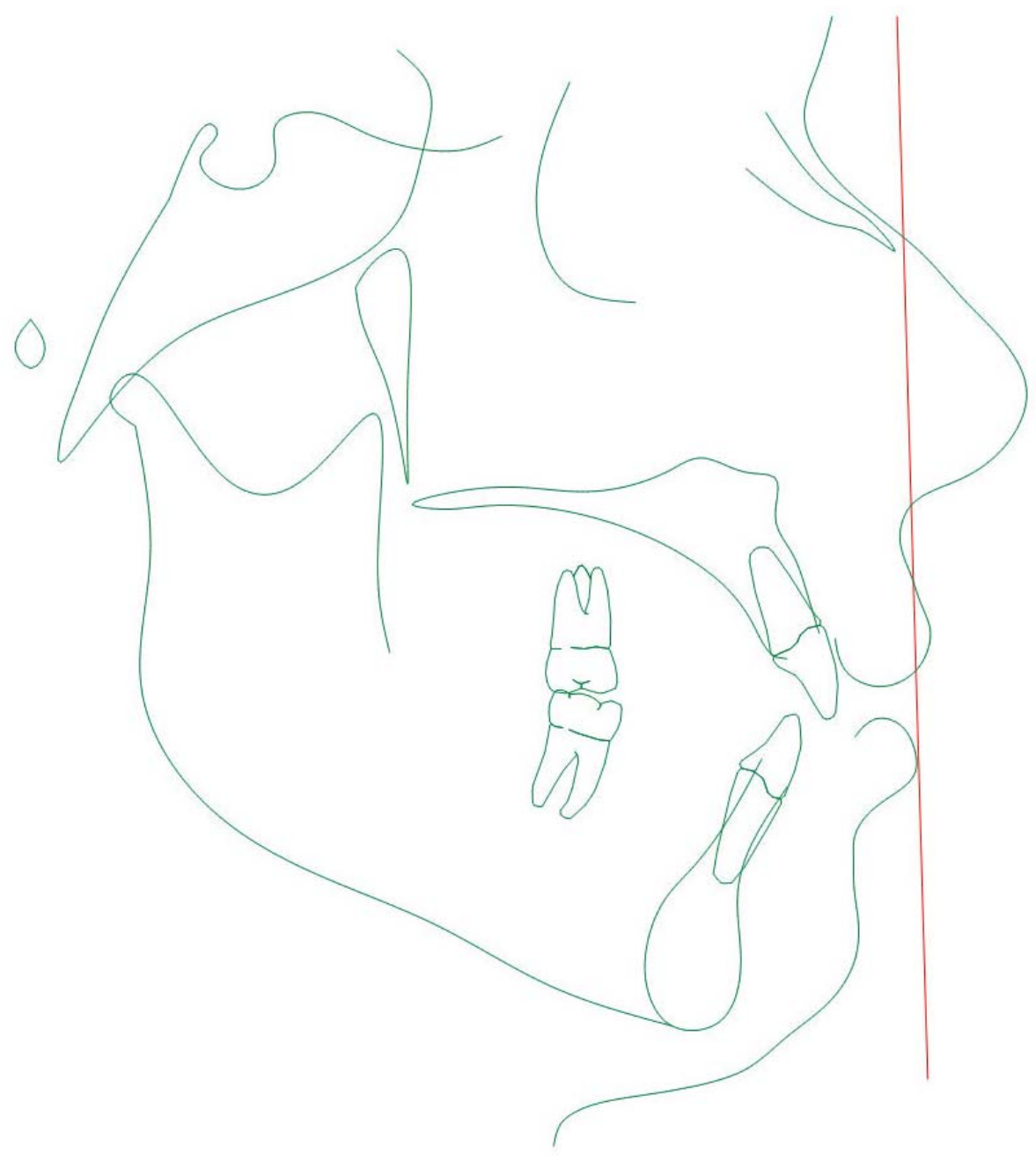

Figura 8 - Linha Vertic al Verda deira. 


\subsubsection{Grandezas Cefalométricas}

Foram utilizadas medidas lineares e angulares.

MEDIDAS DENTOESQUELÉTICAS

1. Altura posterior da maxila (POM-LVV): ângulo formado entre o Plano Oclusal da Maxila e a Linha Vertical Verdadeira (Figura 9)

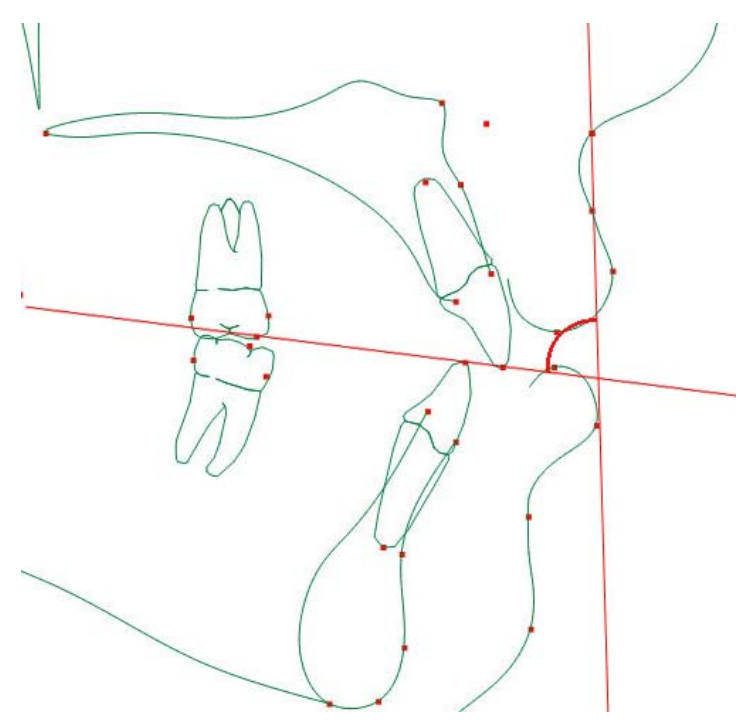

Figura 9 - Altura posterior da maxila (ângulo formado pelo plano oclusal da maxila e a Linha Vertical Verdadeira). 
2. IS-POM: ângulo formado pelo Incisivo Superior e o Plano Oclusal da Maxila (Figura 10)

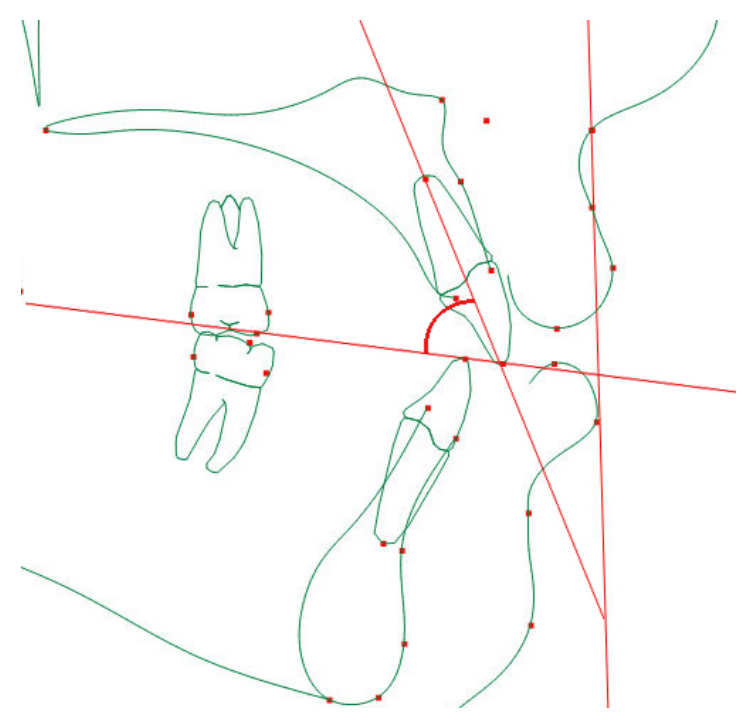

Figura 10 - Ângulo formado pelo incisivo superior e o plano oclusal da maxila.

3. II-POMd: ângulo formado pelo Incisivo Inferior e o Plano Oclusal da Mandíbula (Figura 11)

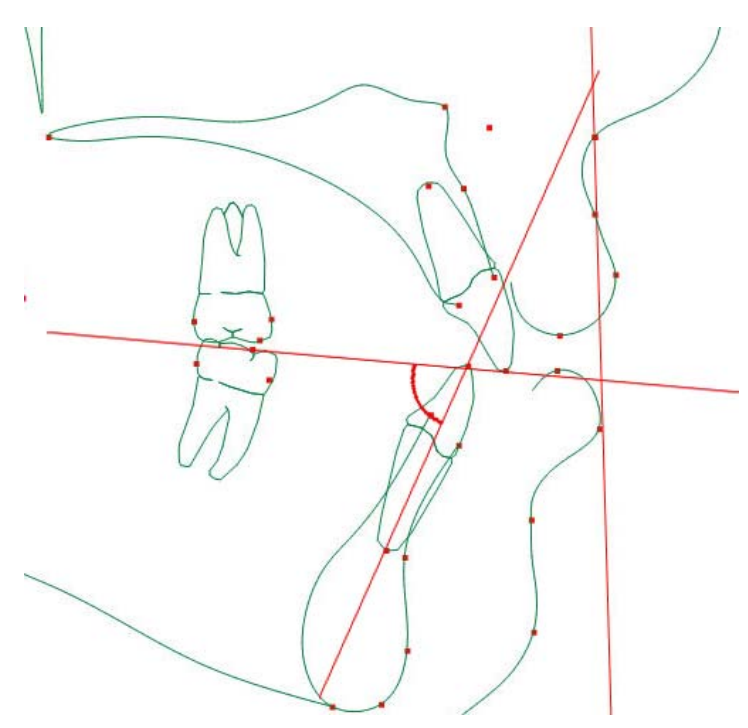

Figura 11 - Ângulo formado pelo incisivo inferior e o plano oclusal da mandíbula. 
4. Overjet (BIS-BII): distância horizontal entre o ponto Borda do Incisivo Superior e o ponto Borda do Incisivo Inferior (Figura 12).

5. Overbite (BIS-BII): distância vertical entre a Borda do Incisivo Superior e a Borda do Incisivo Inferior (Figura 12).

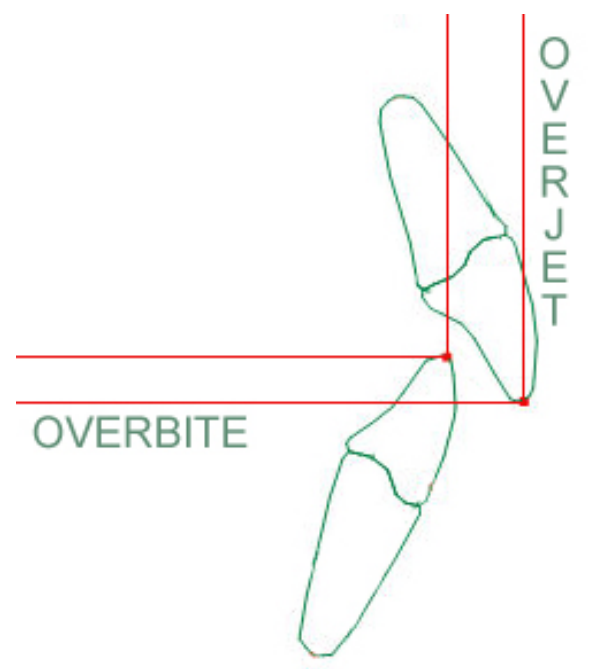

Figura 12 - Overjet e overbite. 


\section{ESTRUTURAS DO TECIDO MOLE (Figura 13)}

6. Espessura do lábio superior (Is-Ls): distância entre o ponto do Incisivo Superior e o ponto Lábio Superior.

7. Espessura do lábio inferior (Ii-Li): distância entre o ponto do Incisivo Inferior e o ponto Lábio Inferior.

8. Espessura do queixo (Pog-Pog'): distância entre o ponto Pogônio e o ponto Pogônio tegumentar.

9. Espessura do mento (Me-Me'): distância entre o ponto Mentoniano e o ponto Mentoniano tegumentar

10. . Ângulo nasolabial (Col-Sn-Ls): ângulo formado pela columela, ponto Subnasal e ponto Lábio Superior (Figura 14).

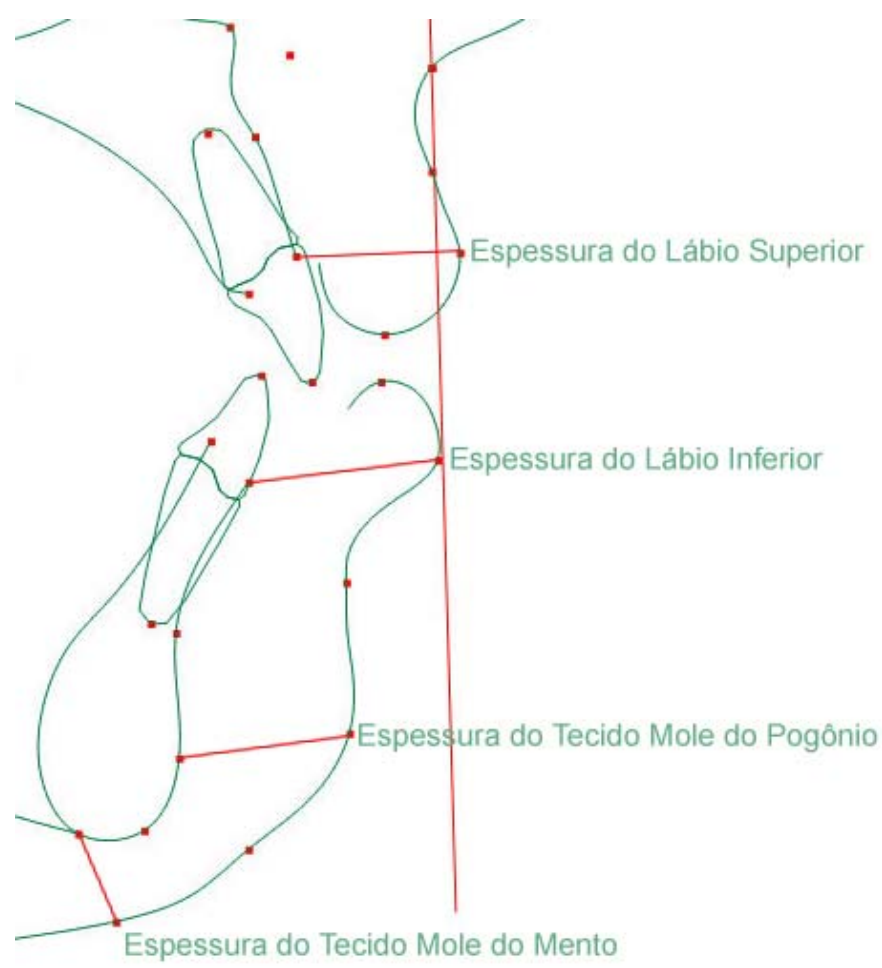

Figura 13 - Espessura do lábio superior, inferior, pogônio e mento. 


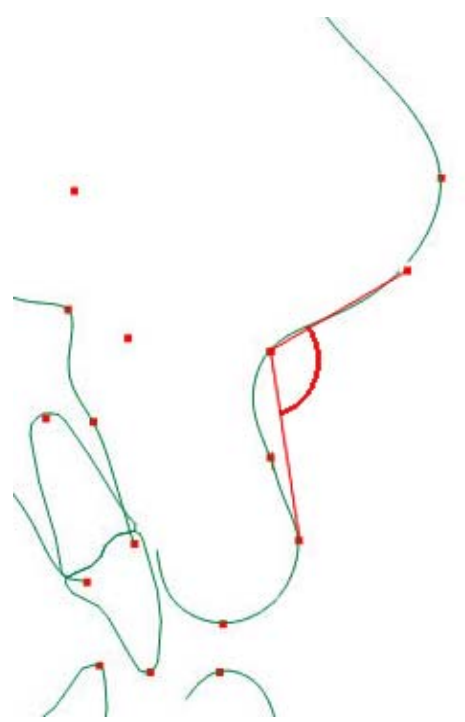

Figura 14 - Ângulo Nasolabial.

11. Ângulo do lábio superior (Ls-Sn-LVV): Ângulo formado entre o ponto Lábio Superior, ponto Subnasal e a Linha Vertical Verdadeira (Figura 15).

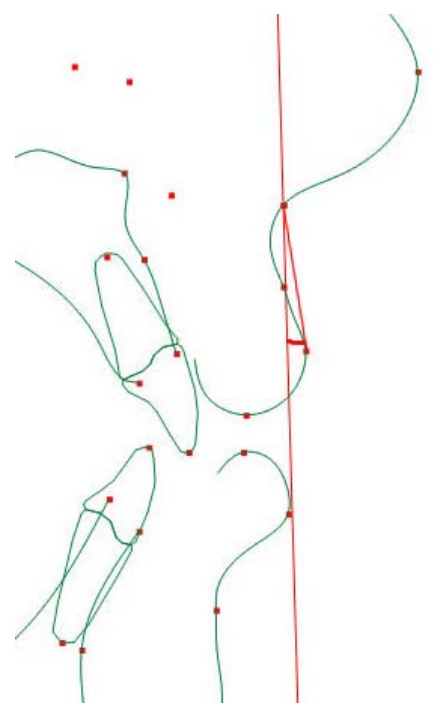

Figura 15 - Ângulo do Lábio Superior. 


\section{COMPRIMENTO FACIAL (Figura 16)}

12. Comprimento facial (N’-Me'): distância entre os pontos Násio tegumentar e Mentoniano tegumentar.

13. Comprimento do lábio superior (Sn-ILS): distância entre o ponto Subnasal e o limite Inferior do Lábio Superior.

14. Gap interlabial (ILS-SLI): distância entre os limites Inferior do Lábio Superior e Superior do Lábio Inferior.

15. Comprimento do lábio inferior (SLI-Me’): distância entre o limite Superior do Lábio Inferior ao ponto Mentoniano tegumentar.

16. Terço inferior da face (Sn-Me'): distância entre os pontos subnasal e Mentoniano tegumentar.

17. Overbite (BIS-BII): distância entre as Bordas do Incisivo Superior e do Incisivo Inferior.

18. Exposição de Incisivo (ILS-BIS): distância entre o limite Inferior do Lábio Superior e a Borda do Incisivo Superior.

19. Comprimento anterior da maxila (Sn-BIS): distância entre o ponto Subnasal e a Borda do Incisivo Superior.

20. Comprimento anterior da mandíbula (BII-Me'): distância entre a Borda do Incisivo Inferior e o ponto Mentoniano tegumentar.

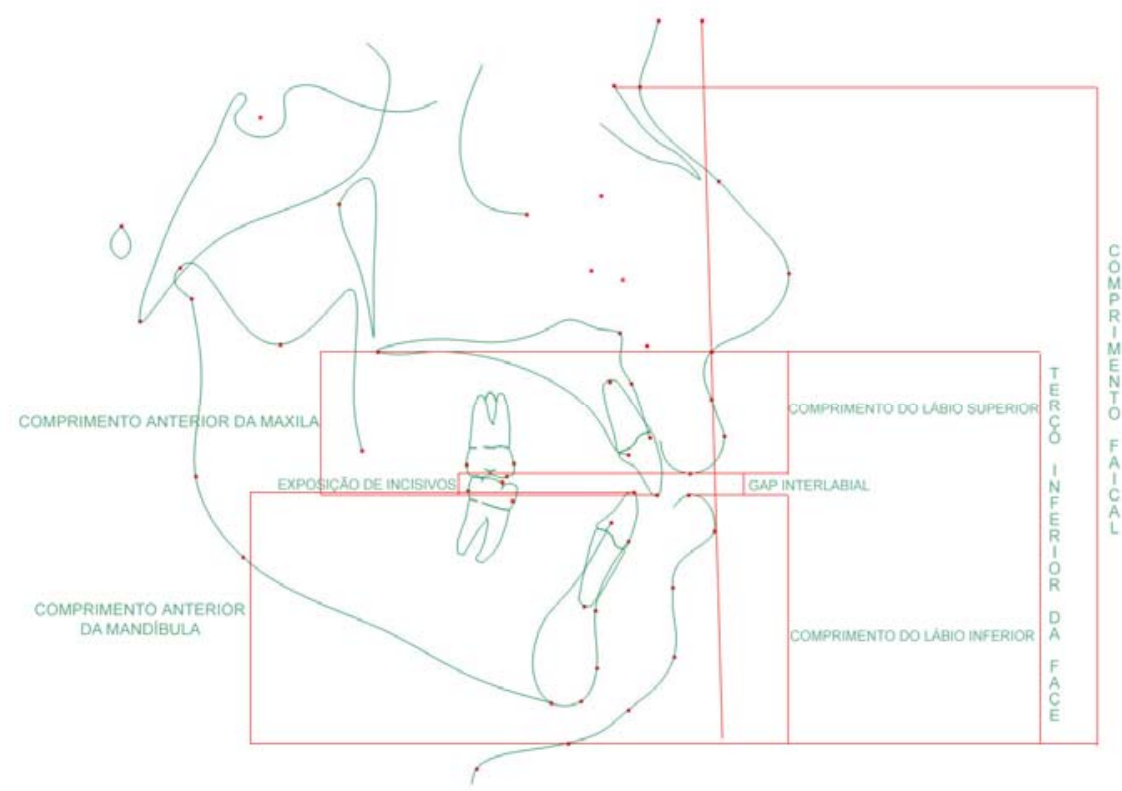

Figura 16 - Comprimento facial. 


\section{PROJEÇÕES EM RELAÇÃO À LINHA VERTICAL VERDADEIRA}

(Figura 17):

21. Gl'-LVV: distância entre o ponto Glabela tegumentar e a linha vertical verdadeira;

22. Io-LVV: distância entre o ponto Infra-orbital tegumentar e a linha vertical verdadeira.

23. Ma-LLV: distância entre o ponto Malar tegumentar e a linha vertical verdadeira.

24. Sp-LVV: distância entre o ponto Subpupilar tegumentar e a linha vertical verdadeira.

25. Bn-LVV: distância entre o ponto Base nasal e a linha vertical verdadeira.

26. Prn-LVV: distância entre o ponto Pronasal e a linha vertical verdadeira;

27. Sn-LVV: distância entre o ponto Subnasal e a linha vertical verdadeira.

28. A'-LVV: distância entre o ponto A tegumentar e a linha vertical verdadeira;

29. Ls-LVV: distância entre o ponto Lábio superior e a linha vertical verdadeira;

30. BIS-LVV: distância entre o ponto Borda do incisivo superior e a linha vertical verdadeira.

31. BII-LVV: distância entre o ponto Borda do incisivo inferior e a linha vertical verdadeira.

32. Li-LVV: distância entre o ponto Lábio inferior e a linha vertical verdadeira;

33. B'-LVV: distância entre o ponto B tegumentar e a linha vertical verdadeira;

34. Pog'-LVV: distância entre o ponto Pog' tegumentar e a linha vertical verdadeira; 


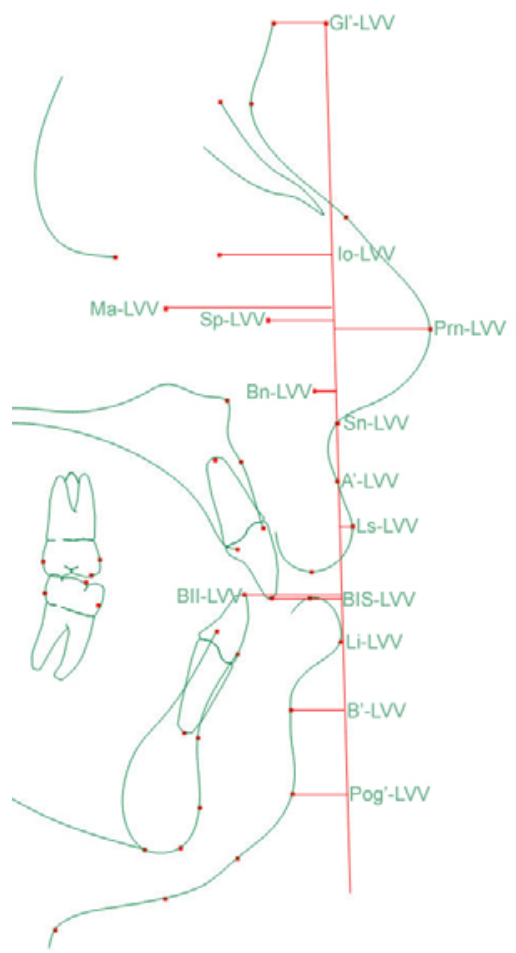

Figura 17 - Projeção dos pontos cefalométricos do tecido mole em relação à Linha Vertical Verdadeira. 


\subsection{Análise Estatística}

Para a avaliação do erro intra-examinador foram realizadas novamente todas as medidas nas telerradiografias de todos pacientes após um intervalo de 15 dias. Determinou-se, desse modo, a diferença entre a primeira e a segunda medição de cada telerradiografia. A aplicação da fórmula proposta por DAHLBERG $\left(\mathrm{Se}^{2}=\right.$ somatória $d^{2} / 2 n$ ) permitiu estimar a ordem de grandeza dos erros casuais. A obtenção dos erros sistemáticos procedeu-se pela aplicação do teste t pareado de acordo com BAUMRIND; FRANTZ, GRAVELY; BENZIES, HOUSTON e RICHARDSON.

Calculou-se a média e o desvio padrão de todas as medidas avaliadas e comparou-as com o padrão americano proposto por ARNETT et al. ${ }^{9}$ através do teste t paramétrico não areado para avaliar a existência de diferença estatisticamente significante. Para a realização do teste t utilizou-se a média, o desvio padrão de cada medida e o número da amostra para homens e mulheres. A fórmula do teste $\mathrm{t}$ foi deduzida no programa Microsoft Excel (Microsoft Corporation) para um nível de significância de 0,05 e a probabilidade (p) foi dada pela função “distribuição do teste t” do próprio programa Microsoft Excel (Microsoft Corporation). 
5- Resultados 



\section{Resultados}

Os resultados obtidos com a análise cefalométrica dos tecidos moles e o erro do método podem ser visualizados nas tabelas abaixo.

TABELA 1: Erro do método da análise cefalométrica do tecido mole utilizando o software Dolphin.

\begin{tabular}{|c|c|c|}
\hline & p (t student) & Erro Dahlberg \\
\hline IS-POM ( $\left(^{\circ}\right)$ & 0,0492 & 6,21 \\
\hline II POMd ( $\left(^{\circ}\right)$ & 0,0046 & 3,55 \\
\hline Overjet (mm) & 0,6148 & 0,16 \\
\hline Overbite (mm) & 0,0320 & 0,41 \\
\hline Altura posterior da maxila (POM-LVV) $\left({ }^{\circ}\right)$ & 0,1794 & 3,55 \\
\hline Comprimento do lábio superior (mm) & 0,0354 & 1,26 \\
\hline Gap interlabial (mm) & 0,0668 & 0,78 \\
\hline Comprimento do lábio inferior (mm) & 0,8286 & 1,59 \\
\hline Terço inferior da face $(\mathrm{mm})$ & 0,3838 & 1,18 \\
\hline Comprimento facial (mm) & 0,1542 & 1,98 \\
\hline Exposição de incisivo (mm) & 0,0112 & 0,46 \\
\hline Comprimento anterior da maxila (mm) & 0,5229 & 1,19 \\
\hline Comprimento anterior da mandíbula (mm) & 0,2839 & 1,03 \\
\hline Espessura do lábio superior (mm) & 0,0089 & 2,00 \\
\hline Espessura do lábio inferior (mm) & 0,4667 & 0,82 \\
\hline Espessura do queixo (Pog-Pog') (mm) & 0,6208 & 0,39 \\
\hline Espessura do mento (Me-Me') (mm) & 0,1026 & 1,15 \\
\hline Glabela tegumentar(mm) & 0,0831 & 0,00 \\
\hline Infra-orbital tegumentar (mm) & 0,5060 & 0,27 \\
\hline Malar Tegumentar (mm) & 0,9685 & 0,39 \\
\hline Subpupilar tegumentar (mm) & 0,9839 & 0,38 \\
\hline Pronasal (mm) & 0,5580 & 0,62 \\
\hline Base nasal (mm) & 0,6232 & 0,57 \\
\hline Subnasal (mm) & 0,00 & 0,00 \\
\hline Ponto A tegumentar (mm) & 0,2162 & 0,89 \\
\hline Lábio Superior (mm) & 0,1330 & 1,42 \\
\hline Borda do incisivo superior (mm) & 0,5276 & 1,74 \\
\hline Ângulo labial ( $\left(^{\circ}\right)$ & 0,0500 & 20,06 \\
\hline Ângulo naso-labial $\left({ }^{\circ}\right)$ & 0,7102 & 22,46 \\
\hline Borda incisivo inferior (mm) & 0,4537 & 1,95 \\
\hline Lábio inferior (mm) & 0,4332 & 1,91 \\
\hline Ponto B tegumentar (mm) & 0,8518 & 1,94 \\
\hline Pogônio tegumentar (mm) & 0,6015 & 3,35 \\
\hline
\end{tabular}


TABELA 2.1: Comparação das medidas dentoesqueléticas brasileiras da análise cefalométrica do tecido mole com o padrão americano para o gênero feminino.

\begin{tabular}{l|cccc}
\hline \multicolumn{1}{c|}{ Dentoskeletal Factors } & Média & Desv. Padr. & Média & Desv. Padr. \\
\hline Mx altura posterior $(\mathbf{M x O P}-\mathbf{T V L}) \mathbf{(}^{\mathbf{}}$ ) & $\mathbf{9 7 , 6 5}$ & $\mathbf{3 , 9 7}$ & $\mathbf{9 5 , 6 0}$ & $\mathbf{1 , 8 0}$ \\
Mx1 a Mx plano oclusal $\left({ }^{\circ}\right)$ & 56,34 & 5,62 & 56,80 & 2,50 \\
Md1 a Md plano oclusal $\left({ }^{\circ}\right)$ & 62,04 & 5,43 & 64,30 & 3,20 \\
Overjet (mm) & 3,34 & 1,02 & 3,20 & 0,40 \\
Overbite (mm) & $\mathbf{1 , 9 4}$ & $\mathbf{1 , 4 7}$ & $\mathbf{3 , 2 0}$ & $\mathbf{0 , 7 0}$ \\
\hline
\end{tabular}

TABELA 2.2: Comparação das medidas dentoesqueléticas brasileiras da análise cefalométrica do tecido mole com o padrão americano para o gênero masculino.

\begin{tabular}{l|cccc}
\multicolumn{1}{c|}{ Dentoskeletal Factors } & Média & Desv. Padr. & Média & Desv. Padr. \\
\hline Mx altura posterior (MxOP-TVL) $\left(^{\circ}\right.$ ) & $\mathbf{9 9 , 1 3}$ & $\mathbf{5 , 2 7}$ & $\mathbf{9 5 , 0 0}$ & $\mathbf{1 , 4 0}$ \\
Mx1 a Mx plano oclusal $\left({ }^{\circ}\right)$ & $\mathbf{5 4 , 1 4}$ & $\mathbf{7 , 0 2}$ & $\mathbf{5 7 , 8 0}$ & $\mathbf{3 , 0 0}$ \\
Md1 a Md plano oclusal $\left({ }^{\circ}\right)$ & 63,66 & 6,20 & 64,00 & 4,00 \\
Overjet (mm) & 3,19 & 0,84 & 3,20 & 0,60 \\
Overbite (mm) & $\mathbf{2 , 4 8}$ & $\mathbf{2 , 3 1}$ & $\mathbf{3 , 2 0}$ & $\mathbf{0 , 7 0}$ \\
\hline
\end{tabular}

TABELA 3.1: Comparação das medidas dos tecidos moles brasileiros da análise cefalométrica do tecido mole com o padrão americano para o gênero feminino.

\begin{tabular}{l|cccc}
\multicolumn{1}{c|}{ Soft Tissue Structures } & Média & Desv. Padr. & Média & Desv. Padr. \\
\hline Espessura do lábio superior (mm) & 12,34 & 1,66 & 12,60 & 1,80 \\
Espessura do lábio inferior (mm) & $\mathbf{9 , 3 6}$ & $\mathbf{1 , 6 2}$ & $\mathbf{1 3 , 6 0}$ & $\mathbf{1 , 4 0}$ \\
Espessura do queixo (Pog-Pog') (mm) & 12,37 & 2,08 & 11,80 & 1,50 \\
Espessura do mento (Me-Me') (mm) & $\mathbf{9 , 5 4}$ & $\mathbf{1 , 5 5}$ & $\mathbf{7 , 4 0}$ & $\mathbf{1 , 6 0}$ \\
Ângulo nasolabial ( $\left(^{\circ}\right)$ & $\mathbf{1 1 0 , 7 9}$ & $\mathbf{7 , 9 9}$ & $\mathbf{1 0 3 , 5 0}$ & $\mathbf{6 , 8 0}$ \\
Ângulo do lábio superior ( $\left(^{(}\right)$ & $\mathbf{4 , 7 4}$ & $\mathbf{8 , 9 6}$ & $\mathbf{1 2 , 1 0}$ & $\mathbf{5 , 1 0}$ \\
\hline
\end{tabular}

TABELA 3.2: Comparação das medidas dos tecidos moles brasileiros da análise cefalométrica do tecido mole com o padrão americano para o gênero masculino.

\begin{tabular}{l|cccc}
\hline \multicolumn{1}{c|}{ Soft Tissue Structures } & Média & Desv. Padr. & Média & Desv. Padr. \\
\hline Espessura do lábio superior $(\mathrm{mm})$ & 15,06 & 2,19 & 14,80 & 1,40 \\
Espessura do lábio inferior $(\mathbf{m m})$ & $\mathbf{9 , 5 9}$ & $\mathbf{2 , 2 0}$ & $\mathbf{1 5 , 1 0}$ & $\mathbf{1 , 2 0}$ \\
Espessura do queixo (Pog-Pog') $(\mathrm{mm})$ & 14,48 & 2,30 & 13,10 & 2,30 \\
Espessura do mento $(\mathrm{Me}-\mathrm{Me}$ ') $(\mathrm{mm})$ & 9,58 & 2,62 & 8,80 & 1,30 \\
Ângulo nasolabial $\left({ }^{\circ}\right)$ & 107,36 & 8,54 & 106,40 & 7,70 \\
Ângulo do lábio superior $\left({ }^{\circ}\right)$ & 4,26 & 8,04 & 8,30 & 5,40 \\
\hline
\end{tabular}


TABELA 4.1: Comparação das medidas do comprimento facial dos brasileiros da análise cefalométrica do tecido mole com o padrão americano para o gênero feminino.

\begin{tabular}{l|cccc}
\hline \multicolumn{1}{c|}{ Facial length } & Média & Desv. Padr. & Média & Desv. Padr. \\
\hline Altura facial (mm) & 128,10 & 5,83 & 124,60 & 4,70 \\
Comprimento do lábio superior (mm) & 21,09 & 2,17 & 21,00 & 1,90 \\
Espaço interlabial (mm) & 3,51 & 1,29 & 3,30 & 1,30 \\
Comprimento do lábio inferior (mm) & 48,14 & 3,69 & 46,90 & 2,30 \\
Terço inferior da face (mm) & 72,74 & 4,55 & 71,10 & 3,50 \\
Overbite (mm) & $\mathbf{- 8 , 4 8}$ & $\mathbf{0 , 0 4}$ & $\mathbf{3 , 2 0}$ & $\mathbf{0 , 7 0}$ \\
Exposição de incisivo Mx1 (mm) & 4,28 & 1,54 & 4,70 & 1,60 \\
Altura anterior Mx (mm) & 25,36 & 2,59 & 25,70 & 2,10 \\
Altura anterior Md (mm) & 49,31 & 2,34 & 48,60 & 2,40 \\
\hline
\end{tabular}

TABELA 4.2: Comparação das medidas do comprimento facial dos brasileiros da análise cefalométrica do tecido mole com o padrão americano para o gênero masculino.

\begin{tabular}{l|cccc}
\hline \multicolumn{1}{c|}{ Facial length } & Média & Desv. Padr. & Média & Desv. Padr. \\
\hline Altura facial (mm) & 131,90 & 5,51 & 137,70 & 6,50 \\
Comprimento do lábio superior (mm) & 23,51 & 2,20 & 24,40 & 2,50 \\
Espaço interlabial (mm) & 2,54 & 1,37 & 2,40 & 1,10 \\
Comprimento do lábio inferior (mm) & $\mathbf{4 9 , 6 8}$ & $\mathbf{3 , 4 7}$ & $\mathbf{5 4 , 3 0}$ & $\mathbf{2 , 4 0}$ \\
Terço inferior da face (mm) & $\mathbf{7 5 , 7 2}$ & $\mathbf{4 , 7 7}$ & $\mathbf{8 1 , 1 0}$ & $\mathbf{4 , 7 0}$ \\
Overbite (mm) & $\mathbf{- 8 , 4 7}$ & $\mathbf{0 , 0 6}$ & $\mathbf{3 , 2 0}$ & $\mathbf{0 , 7 0}$ \\
Exposição de incisivo Mx1 (mm) & 2,79 & 2,13 & 3,90 & 1,20 \\
Altura anterior Mx (mm) & 26,30 & 2,71 & 28,40 & 3,20 \\
Altura anterior Md (mm) & $\mathbf{5 1 , 9 0}$ & $\mathbf{2 , 8 0}$ & $\mathbf{5 6 , 0 0}$ & $\mathbf{3 , 0 0}$ \\
\hline
\end{tabular}

TABELA 5.1: Comparação das medidas da projeção à LVV dos brasileiros da análise cefalométrica do tecido mole com o padrão americano para o gênero feminino.

\begin{tabular}{l|cccc}
\hline \multicolumn{1}{c|}{ Projections to TVL } & Média & Desv. Padr. & Média & Desv. Padr. \\
\hline Tecido mole da Glabela (mm) & $-8,48$ & 0,04 & $-8,50$ & 2,40 \\
Tecido mole da rima orbitária (mm) & $-19,98$ & 1,35 & $-18,70$ & 2,00 \\
Tecido mole da bochecha (mm) & $-21,74$ & 2,31 & $-20,60$ & 2,40 \\
Tecido mole da subpupil (mm) & $-15,12$ & 1,76 & $-14,80$ & 2,10 \\
Tecido mole da base do nariz (mm) & $\mathbf{- 1 1 , 3 3}$ & $\mathbf{1 , 5 6}$ & $\mathbf{- 1 2 , 9 0}$ & $\mathbf{1 , 1 0}$ \\
Projeção nasal (mm) & 16,31 & 1,88 & 16,00 & 1,40 \\
Subnasal (mm) & $\mathbf{0 , 0 0}$ & $\mathbf{0 , 0 0}$ & $\mathbf{0 , 0 0}$ & $\mathbf{0 , 0 0}$ \\
Tecido mole do ponto A' (mm) & $-0,23$ & 1,42 & $-0,10$ & 1,00 \\
Ponto anterior do lábio superior (mm) & 3,17 & 2,44 & 3,70 & 1,20 \\
Mx1 (mm) & $-9,96$ & 3,89 & $-9,20$ & 2,20 \\
Md1 (mm) & $-13,31$ & 4,10 & $-12,40$ & 2,20 \\
Ponto anterior do lábio inferior (mm) & 0,88 & 4,15 & 1,90 & 1,40 \\
Tecido mole do ponto B' (mm) & $\mathbf{- 8 , 0 0}$ & $\mathbf{4 , 6 5}$ & $\mathbf{- 5 , 3 0}$ & $\mathbf{1 , 5 0}$ \\
Tecido mole do pogônio (mm) & $\mathbf{- 5 , 6 9}$ & $\mathbf{5 , 7 0}$ & $\mathbf{- 2 , 6 0}$ & $\mathbf{1 , 9 0}$ \\
\hline
\end{tabular}


TABELA 5.2: Comparação das medidas da projeção à LVV dos brasileiros da análise cefalométrica do tecido mole com o padrão americano para o gênero masculino.

\begin{tabular}{l|cccc}
\multicolumn{1}{c|}{ Projections to TVL } & Média & Desv. Padr. & Média & Desv. Padr. \\
\hline Tecido mole da Glabela (mm) & $-8,47$ & 0,06 & $-8,00$ & 2,50 \\
Tecido mole da rima orbitária (mm) & $-23,51$ & 3,34 & $-22,40$ & 2,70 \\
Tecido mole da bochecha (mm) & $-26,09$ & 4,07 & $-25,20$ & 4,00 \\
Tecido mole da subpupil (mm) & $-18,21$ & 3,81 & $-18,40$ & 1,90 \\
Tecido mole da base do nariz (mm) & $\mathbf{- 1 2 , 9 0}$ & $\mathbf{2 , 7 9}$ & $\mathbf{- 1 5 , 0 0}$ & $\mathbf{1 , 7 0}$ \\
Projeção nasal (mm) & $\mathbf{1 7 , 0 1}$ & $\mathbf{1 , 9 3}$ & $\mathbf{- 1 7 , 4 0}$ & $\mathbf{1 , 7 0}$ \\
Subnasal (mm) & $\mathbf{0 , 0 0}$ & $\mathbf{0 , 0 0}$ & $\mathbf{0 , 0 0}$ & $\mathbf{0 , 0 0}$ \\
Tecido mole do ponto A' (mm) & $\mathbf{- 0 , 7 6}$ & $\mathbf{1 , 4 7}$ & $-\mathbf{3 , 0 0}$ & $\mathbf{1 , 0 0}$ \\
Ponto anterior do lábio superior (mm) & 3,01 & 2,02 & 3,30 & 1,70 \\
Mx1 (mm) & $-12,98$ & 3,26 & $-12,10$ & 1,80 \\
Md1 (mm) & $-16,15$ & 3,31 & $-15,40$ & 1,90 \\
Ponto anterior do lábio inferior (mm) & 0,48 & 3,36 & 1,00 & 2,20 \\
Tecido mole do ponto B' (mm) & $\mathbf{- 1 0 , 1 5}$ & $\mathbf{4 , 2 3}$ & $-\mathbf{7 , 1 0}$ & $\mathbf{1 , 6 0}$ \\
Tecido mole do pogônio (mm) & $\mathbf{- 5 , 7 1}$ & $\mathbf{4 , 9 6}$ & $\mathbf{- 3 , 5 0}$ & $\mathbf{1 , 8 0}$ \\
\hline
\end{tabular}


FIGURA 18: Comparação do padrão brasileiro da análise cefalométrica do tecido mole com o padrão americano. Em vermelho observa-se o perfil do padrão americano, em azul o perfil do tecido mole do padrão brasileiro e em preto, a linha vertical verdadeira.

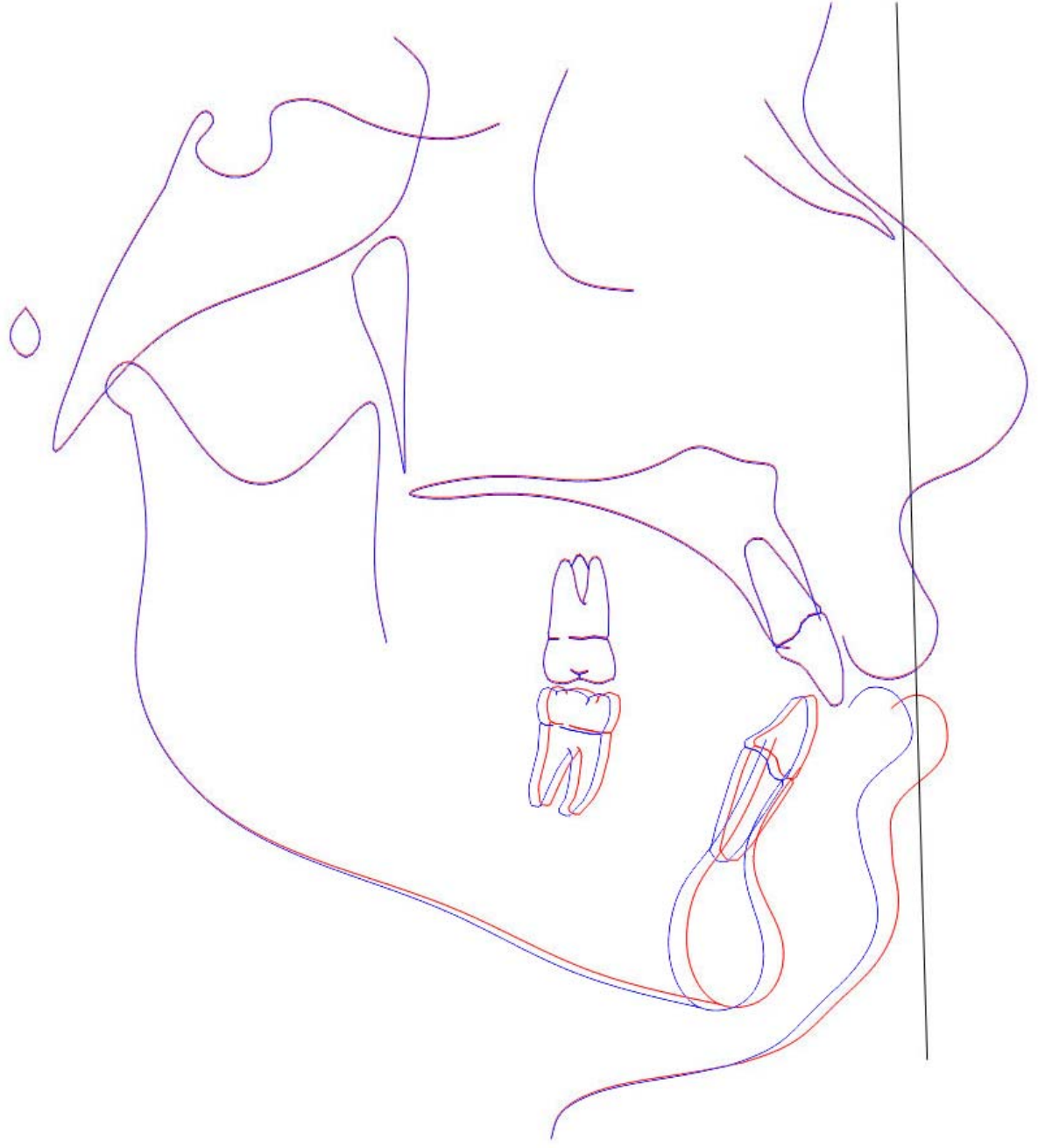



6- Discussão 



\section{Discussão}

No surgimento da cirurgia ortognática o diagnóstico e o plano de tratamento eram baseados exclusivamente nas más oclusões e em grandezas cefalométricas $22,23,39,62,67,86,109,112,141$. Com a pouca tecnologia da época, os modelos de gesso representavam um método de diagnóstico ortodôntico-cirúrgico importante, pois se acreditava que a correção da mordida baseada neste método de diagnóstico alcançaria os objetivos apropriados, inclusive a estética ${ }^{39}$. Hoje sabemos que os modelos de gesso apenas expressavam a má oclusão e proporcionavam aos profissionais da ortodontia ou cirurgia uma falsa impressão da realidade da má posição óssea.

Com o advento do cefalostato ${ }^{22}$ e o desenvolvimento da cefalometria, as radiografias cefalométricas e os modelos de gesso passaram a fazer parte do arsenal que os profissionais tinham nas mãos para diagnosticar e planejar o preparo ortodôntico-cirúrgico. Assim, um grande número de autores se engajou no estudo da cefalometria, possibilitando o surgimento de uma grande quantidades de análises, que se tornaram muito detalhadas ${ }^{26,109,125}$, e por mais de uma décadas essas análises foram consideradas a forma correta de fazer o planejamento dos pacientes cirúrgicos e ortodônticos.

Já nessa época, alguns autores ${ }^{24,40,102,109}$ contestavam a idéia de se basear apenas nas grandezas cefalométricas para o diagnóstico e planejamento ortodônticocirúrgico das discrepâncias dentoesqueléticas. Após aproximadamente duas décadas, passou-se a investigar se os números e grandezas expressados nas cefalometrias eram 
realmente condizentes com resultados faciais considerados agradáveis sob o ponto de vista estético. Muitos autores questionaram as cefalometrias como a única forma de exame e planejamento cirúrgico e a grande maioria dos trabalhos científicos da atualidade comprovam que as análises cefalométricas do esqueleto facial contribuem muito pouco, tanto no diagnóstico como no planejamento de pacientes que irão ser submetidos à cirurgia ortognática ${ }^{18,29,47,78,}$.

Em um estudo realizado por BELL ${ }^{17}$, em pacientes tratados pelo grupo profissional do qual era integrante e, após avaliar exaustivamente os resultados, concluiu que, apesar de uma parte significante dos pacientes obter resultados faciais favoráveis, muitos foram prejudicados esteticamente. Isso pode ser explicado pelo fato de que, naquela época, pouca atenção era dispensada ao perfil tegumentar, resultando em imprecisões, principalmente sob o ponto de vista estético. É necessário considerar que não apenas se desconheciam técnicas precisas para o planejamento estético facial, o que emergiu posteriormente, como também as dificuldades técnicas da cirurgia propriamente dita, limitada à osteotomia da mandíbula por longo tempo. A cirurgia ortognática restringia-se apenas à osteotomia mandibular desde os anos 50 até o início dos anos $70^{99}$, quando publicações consagradas de BELL ${ }^{14}$ e EPKER; WOLFORD $^{43}$ tornaram a cirurgia da maxila uma realidade praticável. De maneira prática e simplificada, podemos dizer que foram aproximadamente 20 anos tratando a quase totalidade dos casos somente com a tão consagrada osteotomia sagital da mandíbula.

Sabendo que a maxila e a mandíbula são dois ossos que nascem e crescem juntos, pode-se assegurar que o crescimento desordenado de um deles, repercutirá de alguma forma no outro; ou seja, de uma maneira simples pode-se concluir que na 
quase totalidade dos casos cirúrgicos a correção deve ocorrer tanto na maxila quanto na mandíbula. Apoiando-se nesse raciocínio, torna-se de fácil entendimento, como já visto pelos relatos da literatura, que é impossível se pensar em tratamento cirúrgico dos ossos da face sem conhecer o seu crescimento ${ }^{59}$. Essa é uma ciência não muito atual, porém, somente há pouco tempo a cirurgia ortognática passou a preocupar-se com esse assunto.

Hoje, com o avanço das técnicas cirúrgicas e os avanços da medicina, pode-se dizer que a realidade é outra da vivenciada por BELL ${ }^{14}$, que tinha grande dificuldade no tratamento de pacientes que necessitavam de cirurgias bimaxilares. O progresso das técnicas cirúrgicas nos permite a chance de realmente movimentar os ossos da maxila e da mandíbula em todos os planos do espaço com total precisão e predicção por meio de planejamentos digitais ultra-especializados e seguros. Os avanços da medicina principalmente na área da anestesiologia, permitem a realização, com total segurança, de cirurgias multissegmentadas da maxila e/ou da mandíbula e de todas as plastias cosméticas da face; o tempo cirúrgico tornou-se relativamente pequeno quando comparado ao que se vivia nos anos 70; a quantidade de sangramento trans e/ou pós-operatório reduziu significativamente e não há mais a necessidade de transfusão sanguínea. Ainda, houve uma diminuição do período de internação. Com todas essas vantagens, tornou-se muito mais fácil pensar na possibilidade de conseguir o resultado almejado das cirurgias corretivas da face.

Segundo as orientações de ARNETT em conversa pessoal, o primeiro passo ao se examinar um paciente cirúrgico é saber o que devemos enxergar no seu rosto para poder corrigir, na totalidade, os defeitos estéticos por ele apresentados e, além disso, proporcionar a este indivíduo as chaves de oclusão propostas por Andrews. 
“Toda vez que nos propomos a corrigir uma má oclusão com intervenção cirúrgica, obrigatoriamente o paciente sofrerá alguma mudança na face e tais mudanças devem, imprescindivelmente, melhorar o perfil facial e proporcionar uma harmonia perfeita a todos os tecidos que recobrem seu rosto”. Isso esclarece porque a quase totalidade das correções cirúrgicas realizadas atualmente apresenta maior complexidade quando comparadas às do passado no entanto os resultados tornaram-se muito melhores, sendo possível, hoje, garantir a satisfação plena dos pacientes submetidos à cirurgia ortognática, além, é claro, de lhes permitir uma maior aceitação do ponto de vista social. Hoje o tratamento ortodôntico-cirúrgico, que era considerado pelos ortodontistas a última opção para tentar solucionar um caso já submetido a todos os recursos ortodônticos, tornou-se a melhor opção para intervir nas más oclusões esqueléticas por grande parte dos ortodontistas.

Como visto na literatura, o tecido tegumentar só passou a ser valorizado pelos ortodontistas como o ponto chave para o planejamento das cirurgias a partir dos anos $80^{27,65,66,71,78,101,139,144}$, embora estudos anteriores já houvessem comprovado a real necessidade, não somente da correta avaliação do perfil mole como também das medidas lineares e angulares de todo o perfil dos pacientes cirúrgicos. Ainda hoje há ortodontistas que são resistentes à utilização de normas exclusivamente tegumentares para o correto diagnóstico e planejamento dos pacientes cirúrgicos portadores das más oclusões de Angle e também que alguns cirurgiões dependiam inteiramente da ortodontia para realizar seus planejamentos. Isso permite entender porque boa porcentagem dos pacientes finalizava o tratamento ortodôntico-cirúrgico com a oclusão satisfatória, porém com resultados indesejados do ponto de vista da estética facial $^{6,7,27,28,33,34,78,79,84,144}$. 
Em 1993, WILLIAN ARNETT ${ }^{6,7}$ publicou um trabalho, dividido em dois artigos, que abordava a análise facial de uma forma bastante apurada, mostrando uma perspectiva um pouco diferente de como deveria se avaliar uma face com o intuito de obter o resultado totalmente esperado pelos pacientes e profissionais. Nestes artigos, o autor considera a cirurgia ortognática uma ciência fundamentalmente estética e funcional tentando demonstrar com palavras claras que a estética é primordial para o sucesso dos pacientes cirúrgicos. Esse modo de enxergar a cirurgia ortognática já havia sido utilizado no passado por alguns autores, mas também contestado por muitos, baseado na premissa da análise facial ser um exame extremamente subjetivo e passível de infinitas variáveis como etnia, cor, conceitos sociais e estéticos de cada povo, além das características pessoais do próprio paciente. O fato da análise facial se encontrar totalmente sujeita à percepção de cada profissional, ortodontista ou cirurgião, poderia fazer com que o diagnóstico baseado neste procedimento apresentasse dificuldades semelhantes às existentes no passado, ou seja, cada profissional acabaria enquadrando os defeitos estéticos de seus pacientes às técnicas cirúrgicas existentes em suas mãos. Ainda, observações e gostos pessoais seriam expressos cirurgicamente, como, por exemplo, exposição dos incisivos superiores, protrusão dos incisivos superiores e inferiores, protrusão dos lábios e do mento mole, além de outros detalhes estéticos de toda a face que estariam totalmente dependentes das percepções do profissional responsável. Isso poderia ter como conseqüências, sem sombra de dúvidas, resultados imprecisos, empíricos e sem padronização.

Ciente das dificuldades vivenciadas pelos profissionais e preocupado em padronizar uma forma precisa da análise facial visando criar um protocolo real de planejamento e tratamento cirúrgico para os pacientes com deformidades 
esqueléticas, ARNETT ${ }^{9}$, em 1999, realizou um estudo num grupo de pessoas que apresentavam perfil normal e oclusão perfeita, sem nunca terem se submetido a tratamento ortodôntico ou cirúrgico. Foram realizadas fotografias e radiografias, ambas de perfil e seguindo os mesmos padrões, de todos os pacientes, resultando numa amostra que poderia servir como padrão de normalidade para os pacientes a serem tratados. Desse estudo resultou um novo tipo de análise cefalométrica dos tecidos moles, baseado em uma linha vertical verdadeira que corre à frente do rosto do paciente e toca o ponto subnasal. Com isso, o autor conseguiu quantificar numericamente as grandezas de todo o perfil facial dos pacientes, medindo todos os pontos selecionados em relação à linha vertical verdadeira. Após aplicar estatísticas em todos esses pontos, obteve-se um perfil médio padrão dos pacientes com grandezas realmente numéricas. As medidas do perfil dos pacientes com discrepâncias dentoesqueléticas podem ser comparadas ao perfil numérico considerado “ideal”, demonstrando a importância dessas grandezas numéricas e sua aplicação no diagnóstico e planejamento dos casos ortodôntico-cirúrgicos. Tornou-se possível determinar a quantidade de movimentação cirúrgica, em milímetros, necessária para atingir o padrão correto estabelecido pelo autor.

Com o auxílio de um software de planejamento cefalométrico, Dolphin Imaging 9.0, o mesmo utilizado por ARNETT e com grandezas numéricas por ele padronizadas $^{9}$, tornou-se muito mais simples planejar uma cirurgia ortognática e diagnosticar todos os defeitos dento-esqueléticos e de perfil facial utilizando como valores-padrão os números de leucodermas norte-americanos. Atualmente este software é utilizado no mundo todo, porém as mesmas imprecisões de resultados obtidas com diferentes tipos de análises podem ocorrer, pois os números 
representativos das grandezas dos tecidos moles não condizem com seres humanos de todo o mundo.

Muitas das análises cefalométricas utilizadas para o diagnóstico e planejamento dos pacientes brasileiros foram anteriormente contestadas, principalmente por terem sido baseadas em amostras obtidas de pacientes de outros países. É preciso ressaltar que as medidas cefalométricas determinadas em um estudo representam a média dos valores da população estudada e não podem ser aplicadas indistintamente para todos os indivíduos, sem considerar os diferentes grupos étnicos ${ }^{50,88}$. Assim, a análise cefalométrica dos tecidos moles criada por ARNETT ${ }^{9}$, apesar de extremamente precisa para pacientes brancos californianos, também apresentaria falhas quando aplicada a indivíduos leucodermas brasileiros, resultando numa forma imprecisa de planejamento. A explicação para essas falhas fundamentase no fato de que o planejamento cefalométrico utilizando os tecidos moles preconizado por $\mathrm{ARNETT}^{9}$ estabeleceu os parâmetros normais para os indivíduos norte-americanos, sendo preciso quando aplicado a esse grupo, e demonstra a necessidade de pesquisar os valores numéricos obtidos em pacientes brasileiros e compará-los aos norte-americanos para verificar se algumas mudanças precisam ser efetuadas para obter resultados tão favoráveis quanto os do autor.

A partir dos resultados obtidos no presente estudo pode-se observar que as grandezas numéricas encontradas no contorno do perfil mole do brasileiro, utilizando exatamente a mesma linha vertical verdadeira utilizada por ARNETT, apresentam-se significantemente diferentes para maioria dos pontos que mapeiam o perfil tegumentar da amostra brasileira. Em média dos números computados, o grupo brasileiro apresenta um perfil mais convexo, com menor protrusão do osso malar, 
menor exposição dos incisivos superiores e mento menos protruído; o sulco mentolabial mostra-se menos pronunciado e os tecidos moles do queixo, um formato menos protruído. Também a altura facial inferior encontra-se diminuída quando comparada ao perfil norte-americano. Em outras palavras, pode-se dizer que, de uma maneira geral, o rosto do brasileiro leucoderma é totalmente diferente do norteamericano leucoderma, assumindo grandezas mais significantes no terço inferior da face, com a altura facial diminuída e terço inferior menos protruído, que determinam um formato médio marcantemente mais convexo. Os valores obtidos mostram que os brasileiros possuem um perfil menos marcante e mais discreto quando comparado aos norte-americanos apresentados no grupo controle ARNETT ${ }^{9}$.

Os dados encontrados alteram completamente o planejamento cirúrgico dos pacientes brasileiros seguindo a técnica da análise cefalométrica dos tecidos moles que tanto contribui para os resultados precisos dos casos planejados e tratados em todo o mundo. Fazendo-se uma analogia, pode-se dizer que se as medidas de outros tipos de análises cefalométricas baseadas em grandezas e ângulos esqueléticos juntamente com algumas medidas do perfil mole criadas por autores nos EUA e utilizadas para o diagnóstico e planejamento da cirurgia ortognática, forem aferidas em brasileiros, poderiam originar números completamente diferentes ${ }^{24,25,50,88}$.

Talvez esta preocupação por nós apresentada deveria ser uma preocupação de todos aqueles que trabalham com pacientes cirúrgicos. Fica claro que provavelmente uma cirurgia ortognática planejada com os números encontrados neste estudo não deveria ser aplicada a indivíduos que fogem às características do grupo estudado, o que nos leva a salientar, uma vez mais, a real necessidade de se pesquisar muito mais 
nessa área no Brasil, pois vivemos em um país onde há uma grande diversidade étnica.

Acreditamos ainda que a análise cefalométrica dos tecidos moles utilizando a linha vertical verdadeira é uma forma muito precisa de avaliar, diagnosticar e planejar o tratamento dos pacientes adultos que irão ser submetidos a intervenção ortodôntico-cirúrgica para correção das deformidades faciais, porém até mesmo para aqueles que estão muito habituados a utilizá-la, existem situações específicas em que o bom senso e o senso estético devem ser considerados com o intuito de obter os melhores resultados cirúrgicos possíveis. Não podemos deixar de considerar ainda que a análise das chaves de harmonia facial deve sempre ser considerada quando se ambiciona precisão de resultados. Também, não se pode deixar de considerar que, para alcançar os melhores resultados, a habilidade técnica para manipular o software de predicção e a habilidade para realizar as técnicas cirúrgicas mais precisas devem estar em perfeito sincronismo, exigindo muitas vezes uma ortodontia muito mais precisa do ortodontista e do cirurgião apurado treinamento técnico tanto do software como das técnicas cirúrgicas mais precisas e atuais que podem conduzir aos resultados mais perfeitos possíveis. 

7- Conclusão 



\section{Conclusão}

A partir da comparação das grandezas numéricas obtidas de pacientes brasileiros com os números estabelecidos para pacientes leucodermas norte-americanos, dentro das condições determinadas neste estudo experimental, julgamos procedente concluir que:

- Os números obtidos na análise do perfil mole dos brasileiros são diferentes dos encontrados nos norte-americanos, exceto em quatro pontos para o gênero masculino e outros quatro, para o gênero feminino.

- Os brasileiros possuem a altura facial um pouco menor quando comparada aos norte-americanos.

- Os brasileiros apresentam o terço inferior da face menos protruído quando comparado aos norte-americanos.

- Pelos números obtidos no presente estudo pode-se padronizar a utilização da analise cefalométrica dos tecidos moles através do software Dolphin para brasileiros. 

Anexos 



\section{Anexos}





\section{Referências}

1. Alcalde R, Jinno T, Orsini M, Sasaki A, Sugiyama R, Matsumura T. Soft tissue cephalometric norms in japanese adults. Am J Orthod Dentofac Orthop 2000;118:84-89.

2. Altemus, LA. Cephalofacial relationships. Angle Orthodont, 38, 3, 175-84, 1968.

3. Andrews L. Entrevista. Rev Dental Press Ortodon Ortop Facial 1997;2:6-7.

4. Angle E. Classification of malocclusion. Dent Cosmos 1899;41:248-264, 350-247.

5. Angle E. Treatment of malocclusion of the teeth. Philadelphia: S.S. White; 1907.

6. Arnett G, Bergman R. Facial keys to orthodontic diagnosis and treatment planning. Part I. Am J Orthod Dentofac Orthop 1993;103:299-312.

7. Arnett G, Bergman R. Facial keys to orthodontic diagnosis and treatment planning. Part II. Am J Orthod Dentofac Orthop 1993;103:395-411.

8. Arnett G, Kreashko R, Jelic J. Correcting vertically altered faces: orthodontics and orthognathic surgery. Int J Adult Orthod Orthognath Surg 1998;13:267-276.

9. Arnett G, Jelic J, Kim J, Cummings D, Beress A, Worley Jr C, Chung B, Bergman R. Soft tissue cephalometric analysis: diagnosis and treatment planning of dentofacial deformity. Am J Orthod Dentofac Orthop 1999;116:239-253.

10. Arnett G. Entrevista. Rev Dental Press Ortodon Ortop Facial 1998;3:6-13.

11. Arnett G, McLaughlin R. Facial and dental planning for orthodontists and oral surgeons. Edinburgh: Mosby; 2004.

12. Auger $\mathrm{T}$, Turley $\mathrm{P}$. The female soft tissue profile as presented in fashion magazines during the 1900s: a photographic analysis. Int J Adult Orthod Orthognath Surg 1999;14:7-18.

13. Bailey L, Proffit W, White Jr R. Trends in surgical treatment of Class III skeletal relationships. Int J Adult Orthod Orthognath Surg 1995;10:108-118. 
14. Bell W. Le Fort I osteotomy for correction of maxillary deformities. J Oral Surg 1975;33:412-426.

15. Bell W, Fonseca R, Kennedy J, Levy B. Bone healing and revascularization after total maxillary osteotomy. J Oral Surg 1975;33:253-260.

16. Bell W, Proffit W, White Jr R. Surgical correction of dentofacial deformities. Philadelphia: W.B. Saunders; 1980.

17. Bell W. Modern practice in orthognathic and reconstrutive surgery. Philadelphia: W.B. Saunders; 1992.

18. Bergman R. Cephalometric soft tissue facial analysis. Am J Orthod Dentofac Orthop 1999;116:373-389.

19. Bittner C, Pancherz H. Facial morphology and malocclusions. Am J Orthod Dentofacial Orthop. 1990 Apr;97(4):308-15.

20. Björk A. Prediction of mandibular growth rotation. Am J Orthod 1969; 55: 585-599.

21. Bowker W, Meredith H. A metric analysis of the facial profile. Angle Orthod 1959;29:149-160.

22. Broadbent B. A new X-ray technique and its application to orthodontia. Angle Orthod 1931;1:45-66.

23. Brodie A. On the growth pattern of the human head: from the third month to the eight years of life. Am J Anat 1941;68:209-262.

24. Burstone C. The integumental profile. Amer J Orthod 1958;44:1-25.

25. Burstone C. The integumental contour and extension patterns. Angle Orthod 1959;29:93-104.

26. Burstone C. Lip posture and its significance in treatment planning. Am J Orthod 1967;53:262-284.

27. Burstone C, James R, Legan H,Murphy G, Norton A. Cephalometrics for orthognathic surgery. J Oral Surg 1978;36:269-277.

28. Capelozza Filho L, Almeida G, Mazzottini R, Cardoso Neto J. Maxillomandibular relationships in patients with dentofacial deformities: diagnostic criteria utilizing three cephalometric analyzes. Int J Adult Orthod Orthognath Surg 1989; 4: 13-26. 
29. Capelozza Filho L. Diagnóstico em ortodontia. Maringá. Dental Press; 2004.

30. Carels C, Willems G. The future of orthodontics. Leuven: Leuven University Press; 1998.

31. Carrea U. In: Monti, editor. Tratado de ortodoncia. Buenos Aires: Ateneu; 1942.

32. Case C. A practical treatise of the technics and principles of dental orthopedia and correction of cleft palate. New York: Quick Lithographers; 1921.

33. Cox N, Van der Linden P. Facial harmony. Am J Orthod 1971;60:175-183.

34. Czarnecki S, Nanda R, Currier G. Perceptions of a balanced facial profile. Am J Orthod Dentofac Orthop 1993;104:180-187.

35. Dal Pont G. Retromolar osteotomy for the correction of prognathism. J Oral Surg 1961;19:42-47.

36. Daugaard-Jensen I. Cephalometrics, orthodontics and facial esthetics. Eur J Orthodont Soc, 1957;33:33-55.

37. Dierkes, JM. The beauty of the face: an orthodontic perpective. Special Issue. J Am Dental Assoc, v115, 89-E - 95 - E, 1987

38. Domingues A, Martins D, Henriques J, Puente J, Papic A. Tratamento ortodôntico-cirúrgico da classe III. Rev Dental Press Ortodon Ortop Facial 1997;2:11-23.

39. Downs W. Variations in facial relationships: their significance in treatment and prognosis. Am J Orthod 1948; 34: 812-840.

40. Downs W. Analysis of the dentofacial profile. Angle Orthod 1956;26:191212.

41. Drobocky O, Smith R. Changes in facial profile during orthodontic treatment with extraction of four first premolars. Am J Othodont Dentofac Orthop 1989; 95:220-30.

42. Ellis E, McNamara J. Cephalometric reference planes: sella nasion vs Frankfort horizontal. Int J Adul Orthod Orthognath Surg 1988;3:81-87.

43. Epker B, Wolford L. Middle-third facial osteotomies: their use in the correction of acquired and developmental dentofacial and craniofacial deformities. J Oral Surg 1975;33:491-514. 
44. Epker B. Modifications in the sagittal osteotomy of the mandible. J Oral Surg 1977;35:157-159.

45. Epker B, Stela J, Fish L. Dentofacial Deformties Integrated Orthodontic and Surgical Correction. St. Louis. Mosby, 1986.

46. Ferrario VF, Sforza C, Serrao G, Colombo A, Ciusa V, Bignotto M. Reliability of soft tissue references for anteroposterior measurement of dental bases. Int J Adult Orthodon Orthognath Surg. 1998;13(3):210-6.

47. Fitzgerald J, Nanda R, Currier G. An evaluation of the nasolabial angle and the relative inclinations of the nose and upper lip. Am J Orthod Dentofac Orthop 1992;102:328-334.

48. Flanary C, Barnwell G, VanSickels J, Littlefield J, Rugh A. Impact of orthognathic surgery on normal and abnormal personality dimensions: A 2year follow-up study of 61 patients. Am J Orthod Dentofac Orthop 1990; 98: 313-322.

49.Flynn TR, Ambrogio RI, Zeichner SJ. Cephalometric norms for orthognathic surgery in black American adults. J Oral Maxillofac Surg. 1989 Jan;47(1):309.

50. Freitas Md. Estudo analítico e comparativo do perfil facial mole, em adolescentes brasileiros, leucodermas, apresentando "oclusão normal", com as diversas linhas estéticas preconizadas Faculdade de Odontologia de Bauru. Bauru: USP; 1978: p. 69.

51. Freitas Md, Henriques J, Pinzan A, Janson G, Siqueira V. Estudo longitudinal das alterações do ângulo nasolabial, em jovens com Classe II, $1^{\text {a }}$ divisão, que se submeteram ao tratamento ortodôntico corretivo. Ortodontia 1999;32:8-16.

52. Garner LD. Soft-tissue changes concurrent with orthodontic tooth movement. Am J Orthod. 1974 Oct;66(4):367-77.

53. Goldsman, S. The variation in skeletal and denture patterns in excellent adult facial types. Angle Orthodont., 1959:v29, n2, 63-92 1959

54. Graber T. A critical review of clinical cephalometric radigraphy. Am J Orthod 1954;40:1-26.

55. Graber T. Problems and limitations of cephalometric analysis in orthodontics.J Am Dent Assoc. 1956 Oct;53(4):439-54. 
56. Gregoret J, Tuber E, Fonseca Ad, Escobar L. Ortodontia e cirurgia ortognática: diagnóstico e planejamento. São Paulo: Ed. Santos; 1999.

57. Gross B, James R. The surgical sequence of combined total maxillary and mandibular osteotomies. J Oral Surg 1978;36:513-522.

58. Hambleton R. The orthodontic curtain. Angle Orthod 1963;33:294-298.

59. Hambleton R. - The soft tissue covering of the skeletal face as related to orthodontic problems. Am. J. Orthodont. 50.6-405-20,1964.

60. Hausser E. The profile of the soft and hard tissue on the face in correct occlusion apud Dent Abstr 1:198-99, 1956.

61. Hellman, M The significance of normal Occlusion. Dental Cosmos, 55, 1913. apud Riedel, R A p.169 RIEDEL, RA. Esthetics and its relation to orthodontic therapy. Angle Orthod, v20, n3, 168-78, 1950

62. Hofrath H. In: Krogman W, Sassouni V, editors. A syllabus in roentgenographic cephalometry. Philadelphia: College Offset; 1957.

63. Holdaway R. The relationship of the bony chin and the lower incisor to the line NB. Pasadena: apud STEINER, CC 1962 p.137; 1955.

64. Holdaway R. Changes in relationship of points A and B during orthodontic treatment. Am J Orthod 1956;42:176-193.

65. Holdaway R. A soft-tissue cephalometric analysis and its use in orthodontic treatment planning. Part I. Am J Orthod Dentofac Orthop 1983;84:1-28.

66. Holdaway R. A soft-tissue cephalometric analysis and its use in orthodontic treatment planning. Part II. Am J Orthod Dentofac Orthop 1984;85:279-293.

67. Holdaway R. apud Steiner 1953.

68. Hunsuck E. A modified intraoral sagital splitting technic for correction of mandibular prognathism. J Oral Surg 1968;26:250-53.

69. Iague Neto G. Avaliação do perfil tegumentar e a sua relação com as estruturas dentoesqueléticas maxilomandibulares, em adultos jovens portadores de oclusão normal e boa estética facial Faculdade de Odontologia de Bauru. Bauru: Universidade de São Paulo; 1998: p. 152.

70. Interlandi S. Gráfico vetorial ortodôntico(versão 2001): processo prático para planificação de tratamento. São Paulo: Artes Médicas; 2001. 
71. Jacobson A. Planning for orthognathic surgery--art or science? Int J Adult Orthodont Orthognath Surg. 1990:5:217-24.

72. Kerr W, Tenhave T. A comparison of three appliance systems in the treatment of class III malocclusion. Eur J Orthod 1988;10:203-214.

73. Krogman W, Sassouni V. Syllabus in roentgenographic cephalometry. Philadelphia: College Offset; 1957.

74. Kumar V. Comparison of conventional and cone beam CT synthesized cephalograms. Dentomaxillofacial Radiology 2007; 36:263-269

75. Labanc J, Turvey T, Epker B. Results following simultaneous mobilization of the maxilla and mandible for the correction of dentofacial deformities: analysis of 100 consecutive patients. Oral Surg Oral Med Oral Pathol 1982;54:607-612.

76. Langlois J, Roggman L. Attractive faces are only average. Psychol Sci 1990;1:1 15-12 11.

77. Le Fort R. Etude experimentale sur les fractures de la machoire superieure. Rev Chirurgical 1901;23:8.

78. Legan H, Burstone C. Soft tissue cephalometric analysis for orthognathic surgery. J Oral Surg 1980;38:744-751.

79. Lehman J. Soft-tissue manifestations of aesthetic defects of the jaws: diagnosis and treatment. Clin Plast Surg 1987;14:767-783.

80. Lindquist J. The lower incisor: its influence on treatment and esthetics. Am J Orthod 1958;44:112-140.

81. Lines $\mathrm{P}$, Steinhauser E. Diagnosis and treatment planning in surgical orthodontic therapy. Am J Orthod 1974; 66: 378-397.

82. Lusterman E. The esthetics of the occidental face: a study of dentofacial morphology based upon anthropologic criteria. Am J Orthod 1963;49:826850.

83. Machado Filho J. Perfis dos “tipos" brasileiros brancos masculinos. Ortodontia.1969:12:113-32.

84. Magalhães A, Stella J, Epker B. Facial anthropometrics versus cephalometry as predictors for surgical treatment in patients with Class III dentofacial deformities. Int J Adul Orthod Orthognath Surg 1995;10:295-302. 
85. Margolis H. Composite x-ray photographs. Am J Orthod 1941;27:717-722.

86. Margolis $\mathrm{H}$. The axial inclination of the mandibular incisors. Am J Orthod Oral Surg 1943;29:571-594.

87. Margolis H. A basic facial pattern and its application in clinical orthodontics. II. Craniofacial skeletal analysis (cont'd), and dento-craniofacial ortientation. Am J Orthod 1953;39:425-443.

88. Martins D. Estudo comparativo dos valores cefalométricos das análises de Downs, Steiner e Alabama, com os de adolescentes brasileiros, leucodermas, de origem mediterrânea Faculdade de Odontologia de Bauru. Bauru: USP; 1979.

89. McLaughlin R, Bennett J, Trevisi H. Mecânica sistematizada de tratamento ortodôntico. São Paulo: Artes Médicas; 2002.

90. McNamara Jr. J. A method of cephalometric evaluation. Am J Orthod 1984;86:449-469.

91. McNamara Jr J, Ellis E. Cephalometric analisys of untreated adults with ideal facial and occlusal relationships. Int J Adult Orthodont Orthognath Surg. 1988:4: 221-231.

92. Merrifield L. The profile line as an aid in critically evaluating facial esthetics. Am J Orthod 1966;52:804-821.

93. Moss J, Linney A, Lowey $\mathrm{M}$. The use of three-dimensional techniques in facial esthetics. Semin Orthod 1995;1: 94-104.

94. Muzj E. Biometric correlations among organs of the facial profile: a possible solution to the present crisis in orthodontics. Am J Orthod 1956;42:827-857.

95. Nanda R, Ghosh J. Facial soft tissue harmony and growth in orthodontic treatment. Semin Orthod 1995;1:67-81.

96. Neger M. A quantitative method for the evaluation of the soft tissue facial profile. Am J Orthod 1959;45:738-751.

97. Nguyen D, Turley P. Changes in the Caucasian male facial profile as depicted in fashion magazines during the twentieth century. Am J Orthod Dentofac Orthop 1998;114:208-217. 
98. Noguchi, N. An orthognathic simulation system integrating teeth, jaw and face data using 3D cephalometry. Int. J. Oral Maxillofac. Surg. 2007;36:640645.

99. Obwegeser H. Zur operationstechnik bei der progenie und anderer unterkieferanomalien. Dtsch Z Mund Kieferheilk 1955;23.

100. Obwegeser $\mathrm{H}$, Marentette L. Profile planning based on alterations in the positions of the bases of the facial thirds. J Oral Maxillofac Surg 1986;44:302-311.

101. Park Y, Burstone C. Soft-tissue profile: fallacies of hard-tissue standards in treatment planning. Am J Orthod Dentofac Orthop 1986; 90: 52-62.

102. Peck H, Peck S. A concept of facial esthetics. Angle Orthod 1970;40:284-318.

103. Perrett D, May K, Yoshikawa S. Facial shape and judgements of female attractiveness. Nature 1994;368:239-242.

104. Pogrel M. What are normal esthetic values? J Oral Maxillofac Surg. 1991:49:963-969.

105. Poulton D. Facial esthetics and angles. Angle Orthodont, 1957:27:133-137.

106. Proffit W, White Jr R, Sarver D. Contemporary treatment of dentofacial deformity. St. Louis: Mosby; 2003.

107. Reis S, Capelozza Filho L, Mandetta S. Prevalência de oclusão normal e má oclusão em brasileiros, adultos, leucodermas, caracterizados pela normalidade do perfil facial. R Dental Press Ortodon Ortop Facial 2002;7:1725.

108. Ricketts R. Planning treatment on the basis of the facial pattern and an estimate of its growth. Angle Orthod 1957;27:14-37.

109. Ricketts R. Cephalometric synthesis: an exercise in stating objectives planning treatment with tracings of the head roentgenogram. Am J Orthod 1960:46:647-673.

110. Ricketts R. Esthetics, environment, and the law of lip relation. Am J Orthod. 1968;54: 272-289.

111. Riedel, R.A. Esthetics and its relation to orthodontic therapy, Angle Orthodontic, 1950: 20:168-78. 
112. Riedel R. An analysis of dentofacial relationships. Am J Orthod 1957;43:103119.

113. Rivera S, Hatch J, Dolce C, Bays R, Van Sickels J, Rugh J. Patients' own reasons and patient-perceived recommendations for orthognathic surgery. Am J Orthod Dentofac Orthop 2000;118:134-140.

114. Robison J, Rinchuse D, Zullo T. Relationship of skeletal pattern and nasal form. Am J Orthod Dentofac Orthop 1986;89:499-506.

115. Rosen H. Maxillary advancement for mandibular prognathism: indications and rationale. Plast Reconstr Surg 1991;87:823-832.

116. Salzmann J. The research workshop on cephalometrics. Am J Orthodont, 1960: 46:834-47.

117. Sassouni V. Diagnosis and treatment planning via roentgenographic cephalometry. Am J Orthod 1958;44:433-463.

118. Scheideman G, Bell W, Legan H, Finn R, Reisch J. Cephalometric analysis of dentofacial normals. Am J Orthod 1980;78:404-420.

119. Scott S, Johnston L. The perceived impact of extraction and nonextraction treatments on matched samples of african american patients. Am J Orthod Dentofac Orthop 1999;116:352-358.

120. Servoss J. The acceptability of Steiner's acceptable compromisses. Am J Orthod 1973;63:161-165.

121. Silva Filho O. Prevalência de oclusão normal e má oclusão em escolares da cidade de Bauru(São Paulo). Parte I: relação sagital. R Odontol da Univ São Paulo 1990;4:130-137.

122. Spiessl B. rigid internal fixation after sagittal split osteotomy of the ascending ramus. In: Spiessl B, editor. New concepts in maxillofacial bone surgery. New York: Springer-Verlag; 1976.

123. Steiner C. Cephalometrics for you and me. Am J Orthod 1953; 39: 729-755.

124. Steiner C. Cephalometrics in clinical practice. Angle Orthod 1959; 29: 8-29.

125. Steiner C. Cephalometrics as a clinical tool. In Kraus B \& Riedel R - Vistas in Orthodontics. Philadelphia: Lea \& Febiger; 1962. p. 131-161. 
126. Stoner M, Lindquist J, Vorhies J, Hanes R, Hapak F, Haynes E. A cephalometric evaluation of fifty-seven consecutive cases treated by Dr. Charles H. Tweed. Angle Orthod 1956;26:68-98.

127. Suguino R, Ramos A, Terada H, Furquim L, Maeda L, Silva Filho O. Rev Dental Press Ortod Ortop Max. 1996;1:86-107.

128. Talass M, Talass L, Baker R. Soft-tissue profile changes resulting from retraction of maxillary incisors. Am J Orthodont Dentofac Orthop 1987: 91:385-94.

129. Trauner R, Obwegeser $\mathrm{H}$. The surgical correction of mandibular prognathism and retrognathia with consideration of genioplasty. Part I. Surgical procedures to correct mandibular prognathism and reshaping of the chin. Oral Surg Oral Med Oral Pathol 1957;10:677-689.

130. Tweed C. The application of the principles of the edgewise arch in the treatment of malocclusion. Part II. Angle Orthod 1941; 11:12-67.

131. Tweed C. Indications for the extraction of teeth in orthodontic procedure. Am J Orthod 1944;30:405-428.

132. Tweed C. A philosophy of orthodontic treatment. Am J Orthod 1945; 31: 74103.

133. Tweed C. Evolutionary trends in orthodontics: past, present and future. Am J Orthod 1953;39:81-108.

134. Tweed C. The Frankfort-Mandibular Incisor Angle (FMIA) in orthodontic diagnosis, treatment planning and prognosis. Angle Orthod 1954;24:121-169.

135. Viazis A. Atlas of orthodontics: principles and clinical applications. Philadelphia: W.B. Saunders; 1993.

136. Waite D, Worms F. Orthodontic and surgical evaluation and treatment of maxillomandibular deformities. In: Irby W, editor. Current advances in oral surgery. St. Louis: CV Mosby; 1974. p. 1-108.

137. Willians R. The diagnostic line. Am J Orthod 1969;55:458-476.

138. Worms F, Isaacson R, Speidel T. Surgical orthodontic treatment planning: profile analysis and mandibular surgery. Angle Orthod 1976;46:1-25.

139. Worms F, Spiedel T, Bevis R, Write D. Post treatment stability and esthetics of orthognathic surgery. Angle Orthodont, 1980; 50:4:251-73. 
140. Wuerpal E. On facial balance and harmony. Angle Ortodont, 1937:7:81-89.

141. Wylie W. The assessment of anteroposterior dysplasia. Angle Orthod 1947;17:97-109.

142. Wylie W. The mandibular incisor: its role in facial esthetics. Angle Orthod 1955;25:32-41.

143. Wylie W. Discussion of "the lower incisor: its influence on treatment and esthetics". Am J Orthod 1959;45:50-54.

144. Wylie G, Fish L, Epker B. Cephalometrics: a comparison of five analyses currently used in the diagnosis of dentofacial deformities. Int J Adult Orthod Orthognath Surg 1987;2:15-36. 

Abstract 



\section{Abstract}

\section{STANDARD PROFILES NORMALITY COMPARATIVE STUDY BETWEEN CAUCASIAN}

BRAZILIANS MEASURES AND NORTH AMERICAN MEASURES.

Considering that modern orthognatic surgery is mainly concerned in planning and diagnosing clinical cases by the use of patients' soft tissue measurements obtained from digital images employed in planning software, the aim of this study is to establish Caucasian Brazilians measures and to compare them to the standard North American measures. For this, a total of 60 Angle's class I patients not previously submitted to orthodontic treatment and presenting harmonious facial features were invited to participate in the study as volunteers. The patients were initially photographed in frontal and lateral views and, afterwards, cephalograms were obtained. The images were digitized, adjusted and indexed in Dolphin's image software. In order to procede cephalometric analysis, a total of 16 soft tissue profile points and 22 hard tissue profile points were demarcated, accordingly to North American original measurements used in Dolphin’s digital image program. After, all cephalograms were again evaluated to determine intra-examiner error according to paired Student's t test. Mean and standard error measures were obtained and compared to American measures by unpaired Student's t test with 95\% confidence level. The results obtained have shown that all measurements, except for four points in male and four points in female, are significantly different $(\mathrm{p}<0.05)$ between Brazilian and American samples. Datas show that Brazilians' soft tissue profile is almost completely different from North Americans', with a less protrusive face, shorter chin projection and a more convex profile. This suggests the necessity of performing some changes in numerical values to obtain an ideal diagnosis and planning of orthognatic surgery in Caucasian Brazilians.

Key-words: facial form, Computer assisted surgery, Orthodontic treatment, cephalometric. 
